\title{
Pressure ulcer prevention in cardiac surgery patients
}

Citation for published version (APA):

Feuchtinger, J. (2005). Pressure ulcer prevention in cardiac surgery patients. [Doctoral Thesis, Maastricht University]. https://doi.org/10.26481/dis.20050929jf

Document status and date:

Published: 01/01/2005

DOI:

10.26481/dis.20050929jf

Document Version:

Publisher's PDF, also known as Version of record

\section{Please check the document version of this publication:}

- A submitted manuscript is the version of the article upon submission and before peer-review. There can be important differences between the submitted version and the official published version of record.

People interested in the research are advised to contact the author for the final version of the publication, or visit the DOI to the publisher's website.

- The final author version and the galley proof are versions of the publication after peer review.

- The final published version features the final layout of the paper including the volume, issue and page numbers.

Link to publication

\footnotetext{
General rights rights.

- You may freely distribute the URL identifying the publication in the public portal. please follow below link for the End User Agreement:

www.umlib.nl/taverne-license

Take down policy

If you believe that this document breaches copyright please contact us at:

repository@maastrichtuniversity.nl

providing details and we will investigate your claim.
}

Copyright and moral rights for the publications made accessible in the public portal are retained by the authors and/or other copyright owners and it is a condition of accessing publications that users recognise and abide by the legal requirements associated with these

- Users may download and print one copy of any publication from the public portal for the purpose of private study or research.

- You may not further distribute the material or use it for any profit-making activity or commercial gain

If the publication is distributed under the terms of Article $25 \mathrm{fa}$ of the Dutch Copyright Act, indicated by the "Taverne" license above, 
PRESSURE ULCER PREVENTION IN CARDIAC SURGERY PATIENTS 
ISBN 3-00-016943-1

(C) Johanna Feuchtinger, Freiburg 2005

Print Burger Druck, Waldkirch

Cover by Kunkler Design, Freiburg 


\section{PRESSURE ULCER PREVENTION IN CARDIAC SURGERY PATIENTS}

\section{Proefschrift}

ter verkrijging van de graad van doctor aan

de Universiteit Maastricht,

op gezag van de Rector Magnificus,

Prof. mr. G.P.M.F. Mols

volgens het besluit van het College van Decanen, in het openbaar te verdedigen

op donderdag 29 september 2005 om 14.00 uur

door

Johanna Feuchtinger 


\section{Promotores}

Prof. Dr. R. de Bie

Prof: Dr. T. Dassen, Humboldt Universităt Berlin, Germany

\section{Co-Promotor}

Dr. R.J.G. Halfens

\section{Beoordelingscommissie}

Prof. Dr. J. Hamers (voorzitter)

Prof. Dr. J. Behrens, Martin Luther Universität Halle, Germany

Prof: Dr. M. Jacobs

Dr. J. Nixon, University of Leeds, UK

Prof. Dr. M. Prins 


\section{CONTENTS}

CHAPTER 1

Introduction

CHAPTER 2

Pressure ulcer risk factors in cardiac surgery: A review of the research literature

CHAPTER 3

The Effect of the "Failure Mode and Effects Analysis" Model

on Pressure Ulcer Incidence in Cardiac Surgery.

CHAPTER 4

Pressure ulcer risk assessment in the early postoperative ICU-period

after cardiac surgery - does it meet the goal?

CHAPTER 5

A $4 \mathrm{~cm}$ thermoactive viscoelastic foam pad on the operating room

table to prevent pressure ulcer during cardiac surgery....

CHAPTER 6

Temperature regulation and pressure ulcer prevention during cardiac surgery

CHAPTER 7

General Discussion

CHAPTER 8

Recommendations

Summary

Samenvatting

Zusammenfassung.

Acknowledgements

Curriculum vitae 


\title{
CHAPTER 1
}

\author{
Introduction
}


This thesis focuses on pressure ulcer prevention in patients following cardiac surgery. The incidence of pressure ulcers in these patients is reported to lie between $4.7 \%$ - 29.5\% (Lewicki et al. 1997, Stordeur et al. 1998).

Pressure ulcer risk factors (Jerusum et al. 1996, Lewicki et al. 1997, Stordeur et al. 1998), the development of pressure ulcers (Lewis \& Grant 1925, Landis 1930, Groth 1942), their risk assessment (Norton et al. 1975, Waterlow 1985, Braden \& Bergstrom 1987, Halfens et al. 2000), suitable preventive interventions and their effectiveness (Hoshowsky \& Schramm 1994, Whittemore 1998, Pokorny et al. 2003), are addressed in research projects.

A pressure ulcer incidence of more than $30 \%$ and the development of serious pressure ulcers in 1999/2000 in the Department of Cardiovascular Surgery at the University Hospital Freiburg gave cause to question the quality of nursing practice.

To scientifically evaluate the practice of pressure ulcer prevention the following questions were asked:

- Where exactly do opportunities for pressure ulcer prevention in the department lie?

- Are there specific risk factors in pressure ulcer development in cardiosurgical patients?

- Is it necessary to perform a specific risk assessment in the patients on the cardiosurgical intensive care unit, since no previous experience exists?

- Can pressure ulcer prevention on the operating table be improved by application of a $4 \mathrm{~cm}$ thermoactive viscoelastic foam pad?

- Does an additional overiay on the warming mattress on the operating table positively influence the patient's rewarming after the cardio-pulmonary bypass?

To further introduce the reader to the pressure ulcer domain relating to the study projects, information is given about the development of pressure ulcers, risk factors, prevention on the operating room table, the special situation of cardiac surgery patients and the continuous improvement in the field.

\subsection{Pressure ulcer development}

"A pressure ulcer is any lesion caused by unrelieved pressure resulting in damage of underlying tissue. Pressure ulcers are usually located over bony prominences (e.g., sacrum, coccyx, hips, heels) and are graded according to the extent of abservable tissue damage, in which grade 1 is defined as "nonblanchable erythema of intact skin. Discoloration of the skin, warmth, oedema, 
induration or hardness may also be used as indicators; particularly on individuals with darker skin". Grade 2 is defined as "partial-thickness skin loss or damage involving epidermis, dermis or both. The ulcer is superficial and presents clinically as an abrasion or blister". Grade 3 is defined as "full-thickness skin loss involving damage to or necrosis of subcutaneous tissue that may extend down to, but not through underlying fascia" and finally grade 4 is defined as "extensive destruction, tissue necrosis, or damage to muscle, bone, or supporting structures with or without full thickness skin loss" (Cuddigan et al. 2001, EPUAP 2005).

The skin, being the largest organ of the human body, protects the body against chemical, bacterial and mechanical influences (Klinke \& Silbernagl 2001). It consists of the epidermis, dermis and subcutis. Nerve cells, sweat glands, hair follicles and in- and outflowing vessels maintain its stability and functionality. Collagen and elastin fibres guarantee equilibrium of pressure and tension in the skin and thus protect underlying tissue layers, muscles and bones. Pressure ulcers develop primarily due to occlusion leading to destruction of the in- and outflowing vessels under persistent pressure. In normal circumstances, a network of blood and lymph vessels provide supply with oxygen and nutrients and the removal of waste products from the skin layers. Autoregulation mechanisms act to maintain a balance between supply and demand of blood and nutrients.

However, the supply and disposal mechanism can be hindered in its function by changes in tissues (e.g. reduction of collagen and fibrin fibres, scarring, inflammations), changes in vessels (arteriosclerosis, inflammatory or autoimmune processes), changes in blood pressure and nerve supply (spinal cord injury, peripheral neuropathy, burns (sunburn, radiation), and finally chemical and mechanical injuries to the skin, the tissue and thus to the in- and outflow blood and lymph vessels (Klinke \& Silbernagl 2001).

In 1925, Lewis \& Grant were the first to describe the reaction to persistent skin pressure. Complete or partial occlusion of the capillary vessels leads to anoxia and to formation of metabolites. The inflowing vessels dilate, allowing formation of a "blood reservoir". If the pressure is relieved, a sudden increase in blood flow occurs (reactive hyperemia). The capability of the vessels for reactive hyperemia is influenced by age and by sclerotic and nerve changes in the vessels.

In 1930, Landis observed that, under extreme pressure to the skin and tissues, the autoregulation mechanism causes the capillary vascular pressure to rise 10 $\mathrm{mmHg}$ higher than the external pressure.

The literature differentiates between open and closed pressure ulcers (Groth 1942, Barton \& Barton 1981). The open pressure ulcer appears as injury to the 
epidermis and dermis, while the closed or "deep" pressure ulcer develops as necrosis in the deeper tissue layers and becomes successively manifest.

\subsection{Pressure ulcer models}

The model designed by Lowthian (1970), which served as the theoretical basis for development of the Norton Scale, was the starting point in 1970 for the conceptualization of risk factors in the development of pressure ulcers. The model focussed on limitations of mobility, activity and sensory perception in combination with pressure as the cause of pressure ulcers. Further developing this model, Braden \& Bergstrom presented their conceptual model in 1987 (Braden \& Bergstrom 1987) as the basis for the Braden scale. The Braden \& Bergstrom model included tissue tolerance, independent of pressure, as a further parameter in the development of pressure ulcers. The most recent model describing the relationships between risk factors and pressure ulcer development is the "conceptual scheme depicting factors in the etiology of pressure sores" published in 1999 by Defloor (1999) (figure 1).

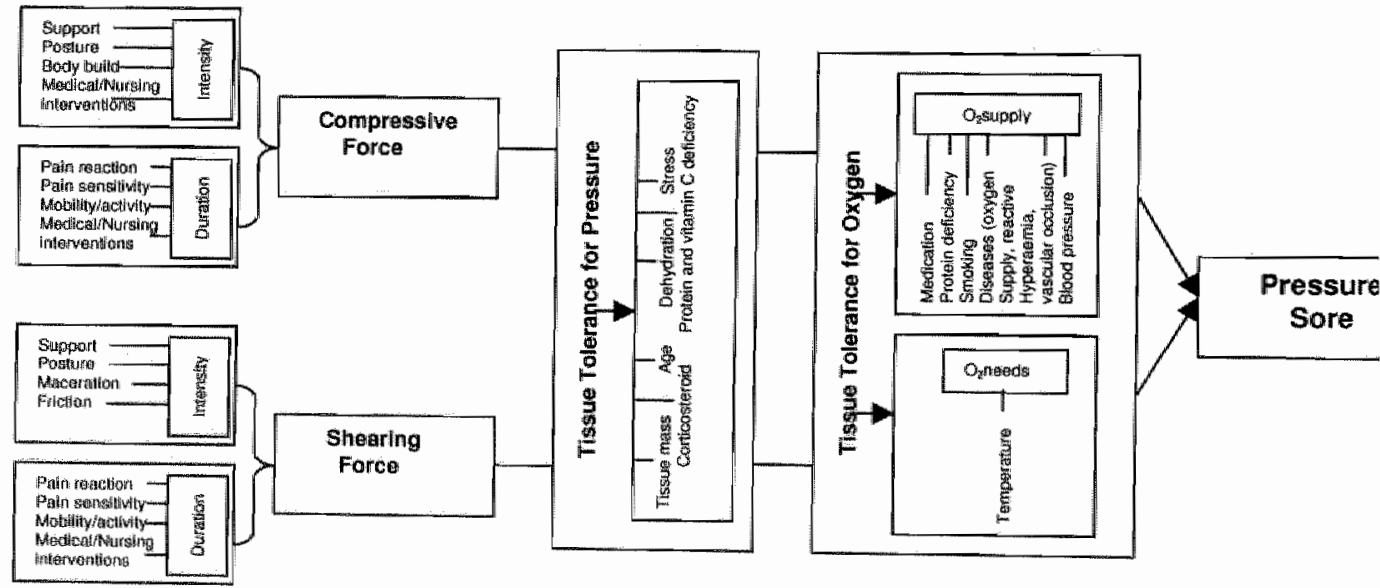

Figure the conceptual scheme depicting factors in the etiology of pressume sores by T. Detlow, 1999

Defloor (1999) developed a conceptual scheme based on research literature describing risk factors in the development of pressure ulcers. Factors considered of most influence were tissue tolerance for oxygen, tissue tolerance for pressure, compressive forces and shearing forces. Contrary to the Braden \& Bergstroms model, his conceptual framework shows that changed tissue tolerance alone does not lead to pressure ulcer development. Compressive and/or shearing 
forces form a prerequisite for the development of pressure ulcers. Tissue tolerance is considered as an intermediate variable and not a causal factor. He states that "sufficiently high pressure for a sufficiently long time will cause pressure sores. How high the pressure must be and how long it must be maintained to cause damage depends on an individual's tissue tolerance. This may vary between subjects. The same applies to shearing forces: here too, tissue tolerance determines whether a pressure sore will develop" (Defloor 1999).

Defloor (1999) sees his conceptual scheme as a basis on which to recognize the interaction between risk factors for pressure ulcer development. The degree of interaction between the risk factors should be addressed by further research. The model can also serve as a basis for further development of risk assessment scales. Finally, the mechanisms that influence measures for preventing development of pressure ulcers can be specified.

\subsection{Pressure ulcer in cardiac surgery patients}

The pressure ulcer incidence among surgical patients varies from $4.7 \%$ (Lewicki et al. 1997) to $66 \%$ (Versiuysen 1986), in cardiac surgery patients from $4.7 \%$ (Lewicki et al. 1997) to $29.5 \%$ (Stordeur et al. 1998). The cause of the sometimes high incidence rates is ascribed to the surgical procedure and the attendant limitations, especially the time lying on the operating table (Vermillion 1990). In this situation, the patient is immobile. Pressure is exerted on the tissue at the body contact sites for the duration of the operation when there is neither pain sensation nor the possibility of changing position. Research shows that the chance of developing a pressure ulcer doubles in operations lasting more than four hours (Hicks 1970, Hoshowsky \& Schramm 1994). Additionally, the underlying disease that necessitates surgery and the surgical intervention influence the patient's tissue tolerance and capacity to react to offset pressure and shearing forces. Supplanting cardio-pulmonary function by a cardiopulmonary bypass influences cardiovascular function, oxygen saturation, blood pressure and perfusion of the peripheral vessels. The use of the cardiopulmonary bypass is standardised to achieve the best-possible surgical results for the patient. But even minimal deviations, especially in skin perfusion, may promote development of pressure ulcers (Kemp et al. 1990). Hypotensive situations which may arise during the operation influence perfusion and have been described as risk factors in pressure ulcer development in patients undergoing cardiac surgery (Jerusum et al. 1996, Stordeur et al. 1998). In addition to intervention in circulation, there is intervention in the patient's temperature balance during cardiac surgery. Reduction of body temperature 
leads on the one hand to reduction of the oxygen requirement and concentration of perfusion in vital organs, while on the other hand, perfusion of the peripheral vessels and thus the skin is also altered. The danger of pressure ulcer development increases (Scott 1999). Due to the influence on the temperature balance, an additional source of heat is usually used on the operating table during cardiosurgical procedures. When the cardio-pulmonary bypass is finished, the patient is protected against further loss of temperature by means of an additional heat source, and a return to normal body temperature is supported. Inadequate warming of the patient and ongoing hypothermia can be seen as an adverse event. Postoperative shivering, muscle shaking and increasing muscle tone are a reaction against the difference between the target temperature and the actual body core temperature. Postoperative shivering is very uncomfortable for the patient, oxygen need increases, peripheral vasoconstriction and blood pressure increases and peripheral oxygen saturation decreases (Jones \& McLarren 1965). Hypothermia contributes to pressure ulcer development (Scott 1999, Scott et al. 2001).

\subsection{Pressure ulcer prevention}

A validated risk assessment instrument is required as the first step in pressure ulcer prevention by the standards of the AHCPR (Panel for the Prediction and Prevention of Pressure Ulcers in Adults 1992) and the National Expert Guideline "Pressure Ulcer Prophylaxis" in Germany (Deutsches Netzwerk für Qualitåtsentwicklung in der Pflege 2004). Systematic risk assessment is a decision-making process (Crow et al. 1995). The potential and actual risk that the patient will develop pressure ulcer(s) must be determined. Planning and implementation of preventive measures are based on this risk assessment. Caregivers have a number of assessment instruments at their disposal. In a systematic review, McGough (1999) showed that the majority of more than 40 risk assessment instruments were developed on the basis of expert knowledge, literature review and/or adaptation of seven original scales. Only one of the seven original scales was developed by regression analysis of an inception cohort study (Salzberg et al. 1996). Most risk assessment scales use a simple ordinal scoring system. The potential differences in the importance of the listed risk factors in pressure ulcer development or a possible cumulative effect of two or more factors is unclear. The validity and reliability of an instrument arises from the concepts, which are included in the instrument. Risk assessment according to the European Pressure Ulcer Advisory Panel (EPUAP 2005) should include: general medical 
condition, skin assessment, mobility, moistness and incontinence, nutrition and pain.

The predictive validity measures the accuracy of prediction of the assessment instrument. Only 6 of 43 available risk assessment scales have been tested for their predictive validity (McGough 1999). The Braden scale is the best-tested assessment scale. However, the results of its predictive accuracy differ, even in the same care setting, e.g., the medical-surgical acute care setting (Bergstrom et al. 1987, Langemo et al. 1991, Barnes \& Payton 1993). An additional problem arises from the fact that the predictive accuracy of an assessment instrument is poorest in those areas where prevention management is best. There is no unequivocal evidence that risk assessment scales are better than the clinical assessment of an experienced caregiver. Cullum et al. concluded that "the evidence on the accuracy of pressure sore risk scales is confusing, and it is not clear that these scales are better than clinical judgement or that they improve outcomes" (Cullum et al. 1995). In the objectives of the Pressure Ulcer Prevention Guidelines of the European Pressure Ullcer Advisory Panels (EPUAP) it is stated that "risk assessment should be used as an adjunct to clinical judgement and not as a tool in isolation from other clinical features" (EPUAP 2005).

The duration and intensity of local pressure and shearing force coupled with the tolerance of the tissue for pressure and oxygen are the main factors in the development of pressure ulcers (Defloor 1999). Foam, gel mats and air systems are available for beds, examination tables and chairs to reduce pressure on the tissue.

In his literature review, Whittemore (1998) provides an overview of research results on pressure-reducing foam overlays or mattresses, static-air overlays and alternating-air overlays as overlays and as replacement mattresses in the patient bed. The literature review shows that 4 -inch $(10 \mathrm{~cm})$ foam overlays reduce pressure more than 2 -inch $(5 \mathrm{~cm})$ overlays. In general, foam overlays are, however, less effective than air overlays. The use of foam overlays is reserved for patients at moderate risk. Static-air overlays and replacement mattresses show the best pressure-reducing properties for high-risk patients. No studies have been performed on $4 \mathrm{~cm}$ thermoactive viscoelastic foam overlays. The results are of limited applicability for the operating table. The "foundation" - the standard mattress on the bed and the padding on the operating table (usually polyurethane) play an additional role in pressure reduction, especially in the case of foam overlays. 
Defloor (2000) tested five operating table mattresses: the standard operatingtable mattress, a foam mattress, a gel mattress, a visco-elastic polyether mattress, and a visco-elastic polyurethane mattress. Interface pressure measurements were performed on 36 healthy volunteers. The foam mattress and the gel mattress seem to have little or no pressure-reducing effect; the polyurethane mattress and the polyether mattress reduce interface pressure significantly better; but none of the mattresses reduces pressure sufficiently to prevent the occurrence of pressure ulcers.

Baker \& Leaper (2003) report on interface pressure measurements of a standard operating table mattress, a pressure-relieving gel pad and an under-the-patient warming device. The pressure-relieving mattresses and warming reduce intraoperative pressure damage.

The decision concerning a pressure ulcer prevention overlay on the operating table can be based at present only with caution on the data of studies performed to date.

Water pads, gel pads, air systems, electric blankets and heaters are available as sources of heat. Scott et al. (2001) tested a forced-air warming therapy against standard therapy and achieved a pressure ulcer reduction from $10.4 \%$ to $5.6 \%$. In a study on 10 volunteers, Baker \& Leaper (2003) determined differences in interface pressure between four mattress combinations: a standard operating table mattress, a pressure-relieving gel pad and an under-patient warming device set at $38^{\circ} \mathrm{C}$ (Pegasus Inditherm System) and at ambient temperature. Both pressure-relieving mattresses and warming reduce intra-operative pressure damage. A mattress with both properties may further reduce pressure damage postoperatively. Pressure ulcer prevention coupled with temperature regulation is a challenge for professional healthcare personnel.

A $4 \mathrm{~cm}$ thermoactive viscoelastic foam overlay is used in several operating rooms for pressure ulcer prevention. It is unclear whether it protects the patient sufficiently against pressure ulcer and how it influences the patient's body temperature course when used in combination with a heating source.

\subsection{Continuous improvement}

Beside the implementation of pressure ulcer prevention programmes, daily practice presents many hazards concerning pressure ulcer development. Continuous improvement is a never-ending challenge for healthcare providers. Quality management systems like the European Foundation for Quality Management, the DIN EN ISO 9000ff and the system of the Joint Commission on 
Accreditation of Health Care Organizations are the basis for continuous improvement processes in many national and international healthcare organizations. Centralized and decentralized quality development projects in the organizations will further develop structures, processes and results.

To assess risks and failures in the prevention process, quality management offers several tools; e.g., the 3F-Method (Mock 2005), the Fault Tree Analysis (Center for System Reliability 2005), the Failure Mode and Effects Analysis (FMEA Infocenter 2005) or audits.

The use of audits as improvement initiatives in the area of pressure ulcers is described by Bours et al. (2004). There have been no studies to pressure ulcer prevention reported on the other instruments cited.

\subsection{Research questions}

Research questions are raised on the basis of the unanswered questions about pressure ulcer prevention in practice. The following research topics arose from the questions of practice:

Which specific risk factors for pressure ulcer development in the cardiac surgery population are identified in the literature (Chapter Two)?

How effective is the use of the Failure Mode and Effects Analysis as a failure prevention method in reducing pressure ulcer occurrence in the cardiac surgery population (Chapter Three)?

How many patients in the intermediate intensive care period after cardiac surgery procedures are "at risk" for pressure ulcer development according to three commonly used risk assessment instruments and which instrument best fits the situation of cardiac surgery intensiv care patients (Chapter Four)?

What is the effect of a $4 \mathrm{~cm}$ thermoactive viscoelastic foam pad on the OR-table in combination with a warming mattress on pressure ulcer incidence and patient's body core temperature in the cardiac surgery population (Chapter Five and Chapter Six)?

\subsection{Outline of the thesis}

This thesis addresses issues, which may be expected to lead to improvement in the prevention of pressure ulcers in cardiac surgery patients. 
In Chapter Two of this thesis, the special risk factors for pressure ulcer formation among cardiac patients in a review of the available research literature are examined. Chapter Three presents a Quality Improvement Project using the Failure Mode and Effects Analysis method. Chapter Four describes a research project on the use of pressure ulcer risk assessment instruments in the cardiac surgery intensive care unit in the first five days after cardiosurgical interventions. Chapter Five presents a randomised controlled trial to test the effect of a $4 \mathrm{~cm}$ thermoactive viscoelastic foam pad on the operating table versus the standard operating table configuration without a pressure-reducing device on the postoperative pressure ulcer incidence in cardiac surgery patients. Chapter Six examines a study of the effect of the $4 \mathrm{~cm}$ thermoactive viscoelastic foam pad on both the postoperative pressure ulcer incidence and the patient's perioperative body temperature course. Chapter Seven summarizes and discusses the results of the study projects. Chapter Eight proposes recommendations for practice and research.

Most of the chapters in this thesis are based on articles published in or submitted for publication to scientific journals and were therefore written with the intention to be read independently. Some overlap between the chapters is therefore inevitable. 


\section{References}

Baker E, Leaper DJ. Pressure-relieving properties of a intra-operative warming device. I Wound Care. $2003 ; 12(4): 156-60$

Bames D. Payton RG. Clinical application of the Braden scale in the acute-care setting. Dermat Nurs. 1993;5:386-388.

Bay $J_{2}$ Nunn JF. Prys-Roberts $C$. Factors influencing arteriall $P_{2} O_{2}$ during recovery from anaesthesia. $\mathrm{Br} J$ Anaesth. 1994:40:398-407

Barton AA, Barton M. The Pressure Sore. The management and prevention of pressure sores. London: Faber; 1981:26-38

Bergstrom N, Braden $B J$, Laguza $A$, Holman $V$. The Braden scale for predicting pressure sore risk. Nurs Res. 1987;36:205-210

Bours GJJQ, Halfens RJG, Candel MJJM, Grol RTPM, Huijer Abu-Saad H. A pressure ulcer audit and feedback project across multi-hospital settings in the Netherlands. Int J Qual Health Care. 2004;16: $211-218$

Braden B, Bergstrom N. A conceptual schema for the study of the etiology of pressure sores. Rehab Nurs. 1987;12:8-12

Center for System Reliability: Fault-Tree-Analysis.

http://reliability.sandia.gov/Reliability/Fault_Tree_Analysis/fault_tree anallysis.htm. Accessed December 12, 2004

Crow RA, Chase J, Lamond D. The cognitive component of nursing assessment an analysis. J Adv Nurs. 1995;22:206-12

Cuddigan J, Ayello EA, Sussman C, Baraoski S. Pressure Ulcers in America: Prevalence, Incidence, and Implications for the Future. Reston, Virginia: NPUAP; 2001, p11

Cullum $N$, Deeks $J$, Fletcher $A$, Long $A$, Mouneimne $H$. Sheldon $T$ et al. The prevention and trealment of pressure sores: How effective are pressuremrelieving interventions and risk assessment for the prevention and treatment of pressure sores? Effective Health Care Bulletin. $1995 ; 2: 1-16$

Defloor T. The risk of pressure sores: a conceptual scheme. J Clin Nurs. 1999;8:206-16

Defloor T, De Schuijmer JDS. Preventing pressure ulcers: an evaluation of four operating-table mattresses. App/ Nurs Res. 2000;13(3):134-41

Deutsches Netzwerk für Qualitătsentwicklung in der Pflege (DNQP). Expertenstandard

Dekubitusprophylaxe in der Pflege. Entwicklung - Konsertierung - Implementierung. Osnabrück:

Fachhochschule, DNOR, Postfach 1940, 49009 Osnabrück. 2004

EPUAP (European Pressure Ulcer Advisory Panel). http:/ wwww.epuap.orgl. Accessed February 2005

FMEA Infocenter. http://www.fmeainfocentre.com. Accessed December 12, 2004

Frank SM, Beattie C, Christopherson $R_{s}$ Norris EJ, Perler BA, Williams GM, Gottlieb SO. Unintentional hypothermia is associated with postoperative myocardial ischemia: The perioperative ischemia randomised anesthesia trial study group. Anesthesiology. 78:468-76 


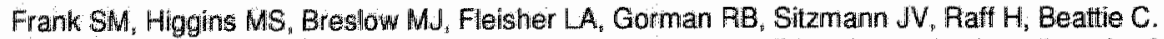
The catecholamine, cortisol and hemodynamic responses to mild perioperative hypothermia. $A$ randomised clinical trial. Anesthesiology. 1995;82:83-93

Groth KE Klinische Beobachtungen und experimentelle Studien über die Entstehung des Dekubitus. Acta Chir Scand. 1942;87(76 Suppl.):209

Hattens RJG, Van Achterberg T, Bal RM. Validity and rellability of the Braden scale and the influence of other risk factors: a multi-centre prospective study. Int J Nurs Stud. 2000:37:313-19

Hicks DJ. An incidence study of pressiure sores following surgery. ANA Clinical Sessions. $1970: 49-54$

Kemp MG el al. Factors that contribute to pressure sores in surgical patients. Res Nurs Health. $1990 ; 13: 293-301$

Hoshowsky VM, Schramm CA. Intraoperative pressure sore prevention: an analysis of bedding materials. Res Nurs and Health. 1994:17:333-339

Jerusum $\downarrow$, Joseph K, Davis JM, Suki R. Balloons, beds and breakdown. Crit Care Nurs Clin North Am. 1996;8:423-40

Jones $\mathrm{HD}_{1}$ McLarren $\mathrm{CAB}$. Postoperative shivering and hypoxaemia after halothane, nitrous oxide and oxygen anaesthesia. Brit J Anaesthesiology. 1965;37:35-41

Klinke A, Silbernagl S. Lehrbuch der Physiologie. 3d ed, Stuttgart: Thieme Verlag; 2001

Landis EM. Micro-injection studies of capillary blood pressure in human skin. Heart. 1930;15:209228

Langemo DK, Olson B, Hunter S, Hanson D, Burd C, Cathcart-Silberberg T. Incidence and prediction of pressure ulcers in five patient care settings. Pressure ulcer. 1991;4:25-36

Lewis T, Grant R. Obserwations upon reactive hyperaemia in man. Heart. 1925;12:73-120

Lewicki LJ, Mion L, Splane KG, Samstag D, Secic M. Patient risk factors for pressure ulcers during cardiac surgery. AORN. 1997;65:933-942

Lowthian P. Bedsores - the missing links? Nurs Times. 1970;46:1454-1458

McGough AJ. A systematic review of the effectiveness of risk assessment scales used in the preetnion and management of pressure sores. University of York. Unpublished MSc Thesis. 1999

Mack. F. 3F-Methad: http//www.mock,cc/3t/risika.htm Accessed December 12, 2004

Norton D, Mclaren $R$, Exton-Smith AN. An Investigation of Geriatric Nursing Problems in Hospital. Edinburgh: Churchill Livingstone; 1975:194-238

Panel for the Prediction and Prevention of Pressure Ulcers in Adults. Clinical Practice Guideline, Number 3: Pressure Uicer in Adults: Prediction and Prevention. Rockville, MD: Agency for Health Care Policy and Research, Public Health Service, US Department of Heath and Human Services, May 1992. AHCPR Publication No. 92-0047

Pokorny $M$, Koldjeski $\mathrm{D}$. Swanson $M$. Skin care intervention for patients having cardiac surgery. Am I Crit Care 2003; 12(6):535-544

Salizberg $C A, B y m e D W$, Cayton $C G_{\text {, }}$ et al. A new pressure ulcer risk assessment scale for individuals with spinal cord injury. Am J Phys Med Rehab. 1996;75:96-104

Scott EM. Intra-operative warming for the prevention of post-operative complications. The Cochrane Library Issue 2. 1999 
Scott EM, Kelly PJ, Clark M, Leaper DJ. Effects of warming therapy on pressure ulcers: a randomised trial. AORN J. 2001;73;921-938

Stordeur S, Laurent S, D*Hoore W. The impontance of repeated risk assessment for pressure sores in cardiovascular surgery. J Cardiovasc Surg. 1998;39(3):343-49

Vermillion C. Operating room acquired pressure ulcers. Pressure ulcer. 1990,3:26-30

Versluysen M. Pressure sores in patients admitted for hip operations. Ger Nurs. 1986;6:20-22,25

Waterlow J. A risk assessment card. Nurs Times. 1985;27:49,51,55

Whittemore R. Pressure-reduction support surfaces: a review of the literature. $\checkmark$ WOCN $1998 ; 25: 6-25$ 


\section{CHAPTER 2}

Pressure ulcer risk factors in cardiac surgery: A review of the research literature

Feuchtinger J, Haliens RJG, Dassen T (2005) accepted for publication in Heart \& Lung 


\section{Abstract}

Background: Pressure ulcer incidence in patients undergoing cardiac surgery is reported to be up to $29.5 \%$ (Stordeur et al. 1998). Common known risk factors for pressure ulcer development include compressive and shearing forces. However knowledge about the specific risk factors in a defined population is heipful in the development of an effective prevention management. This literature review is part of a quality improvement project to reduce pressure ulcer incidence in the cardiac surgery population.

Objectives: The objective is to determine: "which specific risk factors for pressure ulcer development in the cardiac surgery population are identified in the literature".

Results: The results of this literature review indicate a high risk potential in the tissue tolerance for oxygen as temperature manipulation, vasoactive drugs, hypotensive periods and reduced hemoglobin and hematocrit level. Time in the operating room (OR) table, frequency of repositioning, immobility time, older age, low albumin level and corticosteroide are also found as significant risk factors in this population.

Conclusion: The older patient with diseases that influence oxygen supply in combination with the special demands of temperature and circulation regulation during the cardiac surgical procedure places the patient at risk for pressure ulcer development. Prevention measures should be aimed at supporting tissue tolerance for pressure and tissue tolerance for oxygen. These measures should be additional to pressure relieving devices on the OR table and, postoperatively in bed, a defined minimum frequency of postoperative turning and early mobilization after the surgical procedure. 


\section{Introduction}

Pressure ulcers are complex lesions of the skin and underlying structures that vary considerably in size and severity. Pressure ulcers cause a great deal of suffering and frustration to patients, their relatives and caregivers. They also increase the workload of health care professionals and as a consequence increase health care costs dramatically. The cost of caring for patients with pressure ulcers has been estimated to be between $\$ 5000$ and $\$ 40.000$ (Bours et al. 2002, Allman et al. 1986, Imman et al. 1993). In extreme situations pressure ulcers can cause death (Hibbs 1988). National programs have been initiated to manage this problem and to stimulate preventive actions (DOH 1993, Clark et al. 1991, Effective Health Care 1995, DNQP 2002). Knowledge of the risk factors in a particular population is helpful in the development of a prevention program. For patients undergoing cardiac surgery, pressure ulcer incidence is reported to be up to $29.5 \%$ (Stordeur et al. 1998), which is on a high level compared with a pressure ulcer incidence of $0.4 \%$ to $38 \%$ for patients in the general surgical setting (Cuddigan et al. 2001, Schoonhoven et al. 2002). Many risk factors are reported in the literature. As part of a quality improvement project to reduce pressure ulcer development, this literature review was done to identify the risk factors related to cardiac surgery patients.

\section{Theoretical model}

For this study the theoretical model of Defloor (1999) is used. He devised a conceptual scheme depicting factors in the etiology of pressure ulcers (Figure 1).

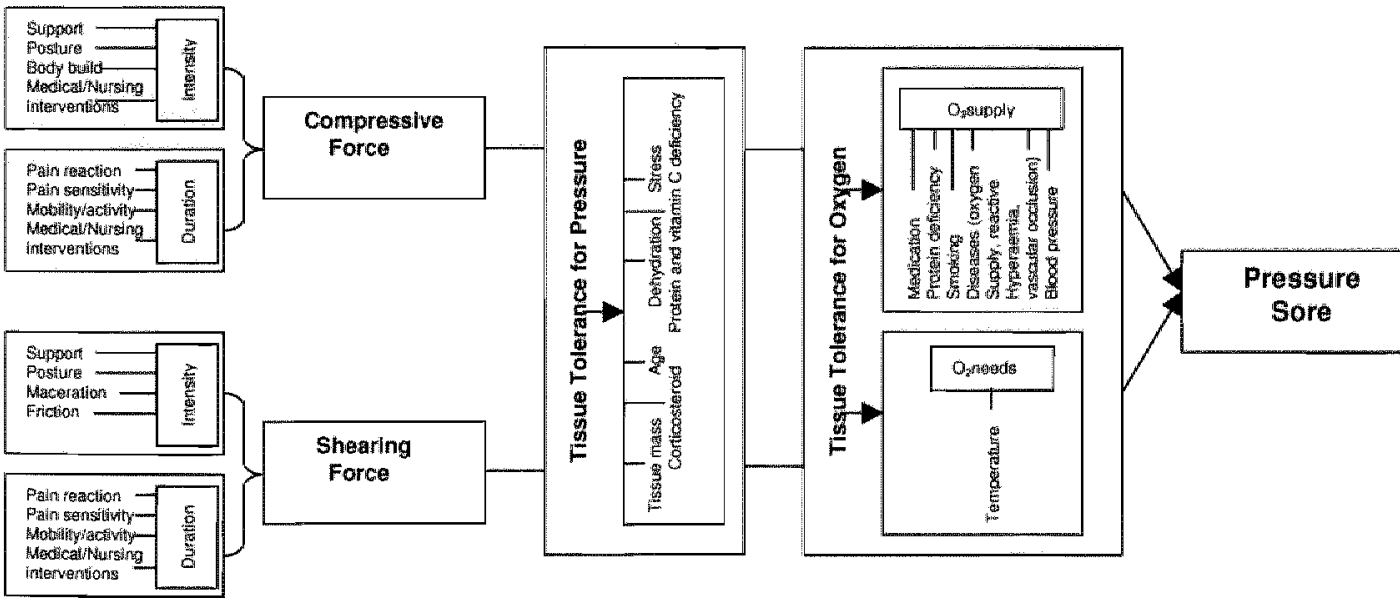

Figure 1 The conceptual scheme depicting factors in the etiology af pressure sones by T. Defloor 1999 
Defloor's (1999) conceptual scheme presents the relationships among factors contributing to the development of pressure ulcers. It may be considered as a further development of the conceptual scheme of Braden \& Bergstrom (1987), which provided the theoretical basis for the scale that Braden developed to detect the risk of pressure ulcer. Braden \& Bergstrom proposed the tissue tolerance as a risk factor for the development of a pressure ulcer. But as Defloor (1999, p. 207) stated: "Tissue tolerance cannot cause pressure sores. The existence of pressure and/or shearing force is needed. Tissue tolerance is considered as an intermediate variable and not a causal factor. Sufficiently high pressure for a sufficiently long time will cause pressure sores. How high the pressure must be and how long it must be maintained to cause damage depends on an individuals tissue tolerance. This may vary between subjects. The same applies to shearing forces: here too, tissue tolerance determines whether a pressure sore will develop. In the presence of shearing force, lower pressure may cause a sore (Bennett \& Lee, 1985; Rowland, 1993)". Each action in pressure ulcer prevention can be related to the theoretical model. E.g., turning the patient in regular intervals reduces the duration of compressive forces or protecting the patients skin of moisture reduces skin maceration and therefore the intensity of shearing forces.

\section{Research question}

This study investigates the following research question: "Which specific risk factors for pressure ulcer development in the cardiac surgery population are identified in the research literature?".

\section{Methods}

\section{Design}

Following the research question a review of the literature provides information about particular risks for pressure ulcer development in cardiac surgery patients with an overview for further implications. 


\section{Studies of investigation}

To identify studies about pressure ulcers in cardiac surgery, the databanks MEDLINE, CINAHL, CARELIT, COCHRANE, Abstract of Reviews of Effectiveness, ACP Journal Club and Evidence Based Nursing Journal were used. Because of changes in surgical procedures and nursing, the search was limited to publications from 1990 onwards. The first search path was heart surgery, cardiac surgery, cardiovascular surgery. Each term was combined (AND) with pressure ulcer, pressure sore, decubitus. Sixty-seven articles were found. Selection criteria for relevant publications were that they had to involve humans, be in English or German, were following scientific criteria (research questions and/or hypothesis, comprehensible descriptions to design, sample, selting, instruments, assessment points, statistical methods, results), measured risk factors and had pressure ulcer formation as an outcome measure. Six articles met the selection criteria. The remaining 61 articles are descriptive clinical reports, opinions and viewpoints.

\section{Published studies of risk factors for pressure ulcer development}

An overview of the six studies is shown in table 1. 


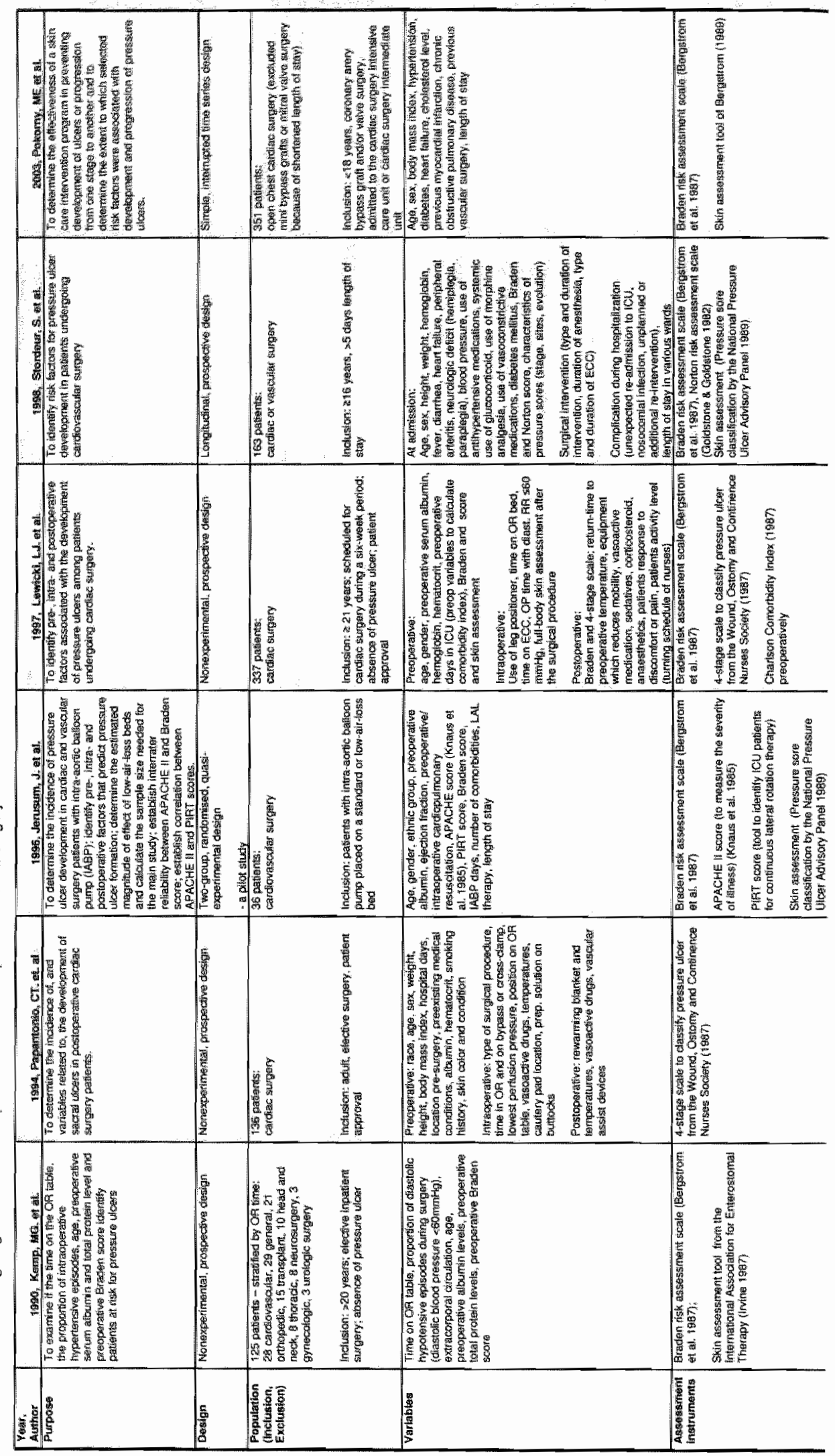




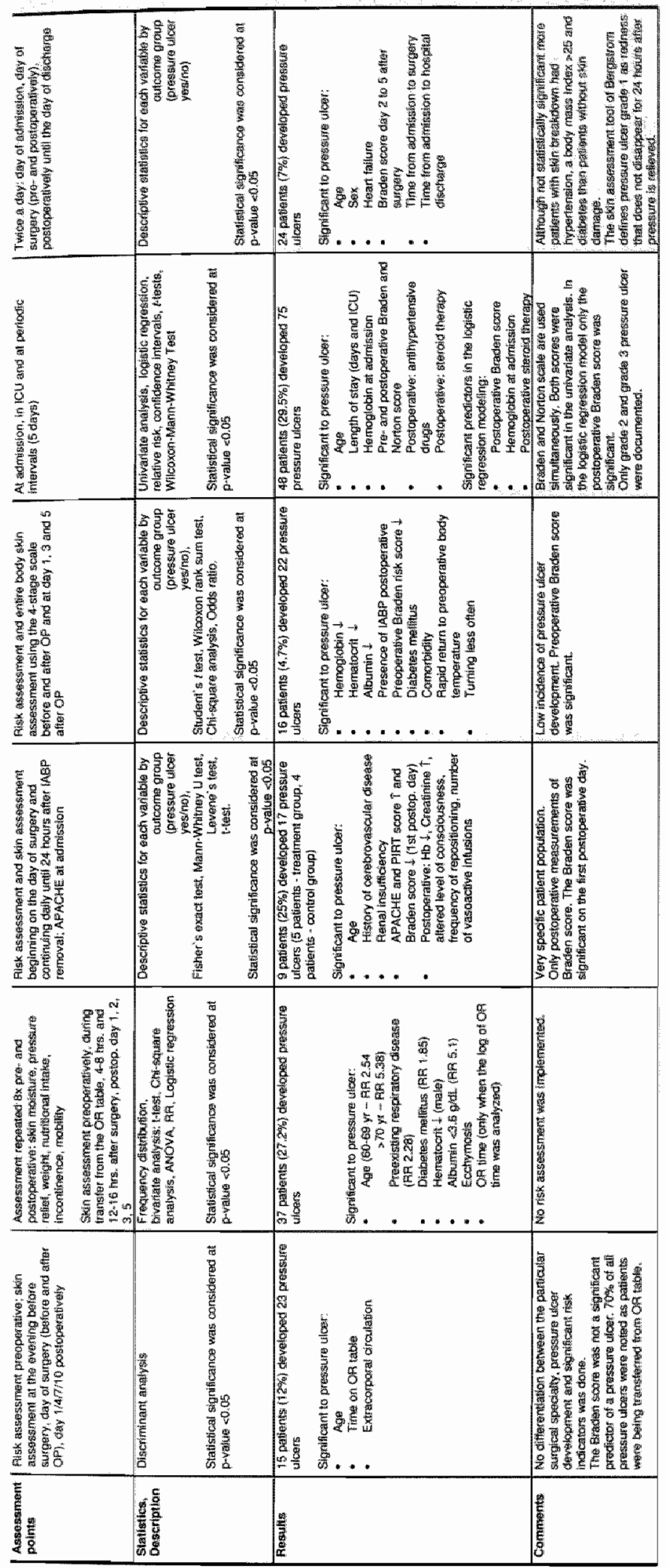




\section{Results}

\section{Kemp et al. (1990)}

Kemp at al (1990) included 125 patients from different disciplines. Of these patients 28 underwent a cardiovascular surgery procedure. They measured seven variables and additionally the risk factors from the Braden scale (Braden et al. 1987) and the results of the skin assessment measured according to the classification of the International Association for Enterostomal Therapy (Irvine 1987). Fifteen of the 125 patients $(12 \%)$ developed 23 pressure ulcers. The incidence of pressure ulcer among the cardiovascular patients is not reported separately. In the discriminant analysis they found age, time on OR-table and the extracorporal circulation as significant risk factor combination for pressure ulcer development. It is salient that the Braden score was not a significant predictor for pressure ulcer development and that $70 \%$ of the pressure ulcers were noted as patients were being transferred from the OR table.

\section{Papantonio et al. (1994)}

Papantonio et al. (1994) included 136 adults in their non-experimental prospective study who were scheduled for elective cardiac surgery. Out of 27 risk factors they found age, preexisting respiratory disease, diabetes mellitus, reduced hematocrit, albumin $<3.6 \mathrm{~g} / \mathrm{dL}$, ecchymosis and the OR-time as significant for patients developing pressure ulcer. 37 patients (27.2\%) developed a pressure ulcer assessed by the 4-grade scale from the Wound, Ostomy and Continence Nurses Society (1987). They did not use a risk assessment instrument.

\section{Jerusum et al. (1996)}

In their two-group, randomised, quasi-experimental study Jerusum et al. (1996) included 36 cardiovascular surgery patients with intra-aortic balloon pump who were lying on a standard or low-air-loss bed. Thirteen variables, including the Braden risk score, were examined as possible risk factors for pressure ulcer development. Nine patients (25\%) developed 17 pressure ulcers. Significantly related to pressure ulcer development were age, history of cerebrovascular disease, renal insufficiency, high APACHE and PIRT scores and a reduced Braden score on the first postoperative day. Also reduced hemoglobin, high creatinine, altered level of consciousness, frequency of repositioning and the number of vasoactive infusions were significantly associated to pressure ulcer 
development at different points in time in the first three_days after the surgical procedure. The Braden score was only assessed postoperatively. The classification system used to classify the pressure ulcers was not reported.

\section{Lewicki at al (1997)}

Lewicki et al. (1997) included 337 patients in their non-experimental prospective study. In addition to the Braden risk score and skin status assessed by the 4stage scale of the Wound, Ostomy and Continence Nurses Society (1987), they had 20 variables under observation. Only 16 patients $(4.7 \%)$ developed 22 pressure ulcers. Reduced hemoglobin, hematocrit and albumin level, the presence of a postoperative intraaortic balloon pump, a low preoperative Braden risk score, diabetes mellitus, comorbidity, rapid return to preoperative body temperature and turning less often were significant for pressure ulcer development.

\section{Stordeur et al. (1998)}

Stordeur et al. (1998) included 163 patients undergoing cardiac or vascular surgery. They monitored 28 variables. Risk was assessed using the Braden scale and the Norton scale (Goldstone \& Goldstone 1982). The variable pressure ulcer was assessed by the classification system of the National Pressure Ulcer Advisory Panel (1989). Forty-eight patients $(29.5 \%$ ) developed 75 pressure ulcers. Variables that were significantly related with pressure ulcer development included age, length of stay, hemoglobin at admission, pre- and postoperative Braden and Norton score, postoperative hypertensive drugs and postoperative steroid therapy. Interestingly in the logistic regression modeling, only the preoperative Braden score, the hemoglobin at admission and the postoperative steroid therapy were found to be significant predictors for pressure ulcer development.

\section{Pokorny et al. (2003)}

Pokorny et al. (2003) included 351 patients undergoing open chest cardiac surgery in their simple interrupted time series study (excluding mini bypass graft and mitral valve surgery due to the short length of stay). They documented eleven variables. Age, sex (female), heart failure, Braden score day 2 to 5 after surgery, time from admission to surgery and from admission to hospital discharge were statistically significant for pressure ulcer development. $24(7 \%)$ patients 
had skin break down (pressure ulcer grade 1-4) assessed by the skin assessment instrument of Bergstrom (2004).

\section{Compressive force and shearing force}

Among the observed variables causing compressive and shearing forces the OR time, frequency of repositioning and a postoperative intraaortic balloon pump are reported as significant risk factors for the development of pressure ulcers whereas none of the researchers found body mass index to be significant.

In two studies a longer stay on the OR table was found to be significant (Kemp et al. 1990, Papantonio et al. 1994). Kemp found that patients with pressure ulcers were on the OR table for 486 minutes whereas patients without a pressure uicer were there for 298 minutes on average. Papantonio found that mean OR times of 375 minutes for patients with and 335 minutes for patients without pressure uicers were significant in combination with the time in the induction room (in log transformation). In two studies a significantly higher risk was found for patients with reduced mobility in the immediate postoperative period (Jerusum et al. 1996, Lewicki et al. 1997). The patient's activity level "as defined by the turning schedules nurses followed had an impact on the development of a pressure ulcer. An altered level of consciousness (Jerusum et al. 1996), which influences the pain sensitivity and reaction, was also a relevant indicator. Additional medical interventions such as an intraaortic balloon pump also had an impact to pressure ulcer development (Papantonio et al. 1994) in this population. Maceration and friction were not studied.

\section{Tissue tolerance for pressure}

In four studies higher age was found to be a predictive factor for pressure ulcer development (Kemp et al. 1990, Papantonio et al. 1994, Jerusum et al. 1996, Pokorny et al. 2003). Jerusum et al. (1996) reports a mean age of 68 years for patients with and 62 years for patients without pressure ulcers. In Kemp's study (1990) the patients with pressure ulcers had a mean age of 60.87 years (SD 12.12) and without pressure ulcers of 57.13 years (SD 14.42). In Lewicki's study (1997) age was not a significant predictor for pressure ulcer development. Papantonio (1994) reported a relative risk of 2.54 for patients between $60-69$ and 5.38 for patients $>70$ years. In Stordeur's study (1998) patients with a pressure ulcer had a mean age of 67.1 (SD 10.7) years and patients without a pressure ulcer 63.4 (SD 11.5) years. However these results were not significantly associated with pressure ulcer development. In the skin breakdown group in the 
study of Pokorny (2003) the patients mean age was 72 years (SD 5.9). A reduced albumin level was found to be significant by Papantonio (1994) and Lewicki (1997). Stordeur (1998) found corticosteroid medication to be a risk factor. Other variables such as tissue mass, dehydration, vitamin $C$ deficiency and stress were not studied.

\section{Tissue tolerance for oxygen}

Special procedures in cardiac surgery include extracorporal circulation and reducing of body temperature. As a consequence, the peripheral blood vessels are vasoconstricted and there is a reduced supply of blood to the tissue. The use of extracorporal circulation (ECC) was found to be significant by Kemp (1990). Temperature management had a significant influence on pressure ulcer development in the study of Lewicki (1997), especially the rapid return to the preoperative body temperature. The number of hypotensive periods and vasoactive drugs were associated with pressure ulcer in two studies (Stordeur et al. 1998, Jerusum et al. 1996).

Reduced hemoglobin concentration was found to be a predictive factor in pressure ulcer development in patients undergoing cardiac surgery (Stordeur et al. 1998, Lewicki et al. 1997). In two studies a reduced hematocrit level was also reported to be significant for pressure ulcer development (Papantonio et al. 1994, Lewicki et al. 1997), whereby in the study of Papantonio et al. (1994) only the hematocrit in the male population was significantly associated.

Comorbidities seem to have a relevant influence on pressure ulcer development. Papantonio (1994), Jerusum (1996), Lewicki (1997) and Pokorny (2003) found diabetes mellitus, ecchymosis, a history of cerebrovascular disease, renal insufficiency, heart failure and comorbidity in general to be significant. Smoking was not a significant risk indicator. All findings for compressive and shearing forces, tissue tolerance for pressure and tissue tolerance for oxygen are summarized in table 2.

\section{The risk}

The risk idlentified through a risk assessment instrument was studied by each author except Papantonio (1994). In five studies the Braden Scale was used to explore the risk factors (Stordeur et al. 1998, Kemp et al. 1990, Jerusum et al. 1996, Lewicki et al. 1997). Stordeur (1998) additionally used the Norton Scale. As common assessment point, Stordeur (1998), Lewicki (1997), Kemp (1990) and Pokorny (2003) assessed the risk preoperatively. Here the risk scores are 
between 19.3 and 20.6 for patients who developed pressure ulcers postoperatively. Jerusum (1996), Stordeur (1998) and Pokorny (2003) collected the postoperative Braden risk scores. For patients who developed a pressure ulcer the scores were between 9.0 and 12.0 at the ICU and between 13.9 and 16 after the ICU. The scores are presented in table 2. The Braden scores assessed at different points in time were significant apart from in Kemp's study. What is remarkable are the different risk scores for pressure ulcer development in the evaluated studies.

Table 2 Significant risti factors tot pressure ullcer development in cardiac surgery according to Defloor's conceptual scherne, and the Biraden risk assessment scores

\begin{tabular}{|c|c|c|c|c|c|c|c|c|c|c|c|}
\hline \multirow{2}{*}{ 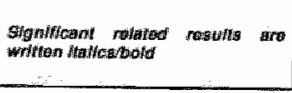 } & \multicolumn{2}{|c|}{ KKemp et at. (1990) } & \multicolumn{2}{|c|}{$\begin{array}{l}\text { Papantonio of ath } \\
\text { (1994) }\end{array}$} & \multicolumn{2}{|c|}{$\begin{array}{l}\text { Jurusium et. all. } \\
\text { (1996). }\end{array}$} & \multicolumn{2}{|c|}{$\begin{array}{l}\text { Lowflek } \\
(1997)\end{array}$} & \multicolumn{2}{|c|}{$\begin{array}{l}\text { Stiprdeur at al. } \\
(1998)\end{array}$} & \multirow{2}{*}{ 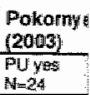 } \\
\hline & 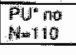 & $\begin{array}{l}P U_{\text {yes }} \\
\mathrm{A}=16\end{array}$ & $\begin{array}{l}\text { Punto } \\
\text { Nam } 99\end{array}$ & $\begin{array}{l}\text { Putyes } \\
\text { Ning7 }\end{array}$ & $\begin{array}{l}P=170 \\
N=30\end{array}$ & $\begin{array}{l}\text { Puyes } \\
\mathrm{Pu}=6\end{array}$ & $\begin{array}{l}\text { Pif no } \\
\mathrm{N}=3 \mathrm{~m}, \mathrm{1}\end{array}$ & $\begin{array}{l}\text { Pif yes } \\
\text { Nmige }\end{array}$ & $\begin{array}{l}\text { Ful } n: 0 \\
\text { Naly }\end{array}$ & $\begin{array}{l}\text { pit wes } \\
\mathrm{N}=1 \mathrm{~S}\end{array}$ & \\
\hline \multicolumn{12}{|l|}{ Cownderestive and shetarting yorces } \\
\hline 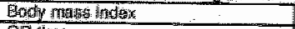 & $\therefore$ & $\because-$ & 26.6 & 28.6 & $\therefore$ & - & - & $x$ & 25.6 & 26.3 & . \\
\hline Of lime & 2988 in: & $466^{\prime \prime n}$ & 335 anta & $374 \mathrm{mln}$ & $2 \times 0 \mathrm{~min}$ & $3 / 35 \mathrm{~m} / \mathrm{m}$ & $300 \mathrm{~min}$ & 372 min & $265 \mathrm{~min}$ & 284 min & - \\
\hline 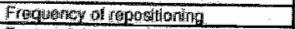 & $\therefore$ & 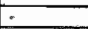 & $\because$ & - & $?$ & sgn. & L. & Silgn ${ }^{2}$ & $\therefore$ & - & - \\
\hline 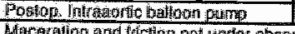 & 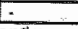 & $\because$ & 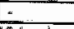 & $\therefore$ & 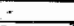 & + & 4 & Sling. & 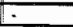 & - & - \\
\hline
\end{tabular}

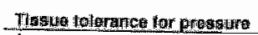

-mong

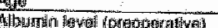

Corlicosiarid:

This wie mase

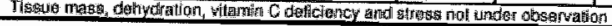

Tigighe tolorance tor owyoun

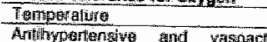

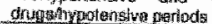

Exlraforporal circulatition:

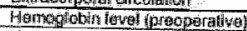

Hiantatocut lavel foreoperatival

Praexisting resigatary eliseage

Dintiventas meititus

Eorituymosis

Aanal Insubletengy

High APACHE sCOPO

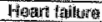

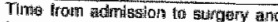

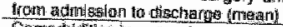

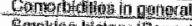

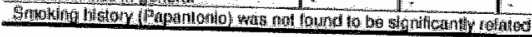

\begin{tabular}{|c|c|c|c|c|c|c|c|c|c|c|}
\hline - & $\therefore$ & $\therefore$ & $\therefore$ & $\cdot$ & $=$ & $=$ & $\sin n^{2}$ & $\therefore$ & - & $\div$ \\
\hline - & $"$ & $=$ & - & $*$ & Shgrr. & 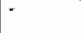 & 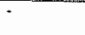 & - & sign. & " \\
\hline & Stgn $n=6$ & 103 rnin & 114. rrin & 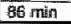 & 127 min & $10 \mathrm{~s}$ min & $00 \mathrm{~min}$ & 102 malin & $114 \mathrm{mmin}$ & $*$ \\
\hline ine & $\therefore$ & 4 & & $=$ & $\therefore$ & $14.1 \mathrm{~g} / \mathrm{d}$ & $\sqrt{2.7 \mathrm{gdd}}$ & $13.6 \mathrm{~g}$ ind & $12.1 \mathrm{Q} / \mathrm{d}$ & 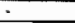 \\
\hline . & " & $\begin{array}{l}0^{* 41.7 \%} \\
9^{37.5 \%} \\
\end{array}$ & $0^{34.7 \%}$ & $"$ & $x$ & $42.2 \%$ & $35.7 \%$ & 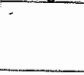 & $x$ & - \\
\hline 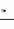 & $\ldots$ & $-\ldots$ & Sigon. & $\therefore$ & 4 & - & 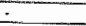 & 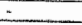 & 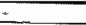 & - \\
\hline$:$ & $=$ & - & Slger & $=$ & 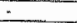 & - & Sign. & $\therefore$ & $=$ & - \\
\hline- & 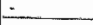 & $\approx$ & Sygn & - & - & $\therefore$ & $\therefore$ & - & - & 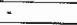 \\
\hline$\div$ & 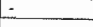 & $\therefore$ & שي & $=$ & 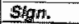 & $\div$ & $n$ & $\therefore$ & - & 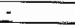 \\
\hline$=$ & $\therefore$ & $=$ &. & - & Slgn: & $=$ & $=$ & $=$ & - & 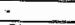 \\
\hline - & 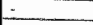 & - & $\dot{m}$ & $\therefore$ & $\therefore$ & - & $\therefore$ & $=$ & - & slgn. \\
\hline - &. & . & 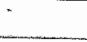 & . & $\because$ & $\cdot$ & . & 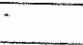 & - & $\begin{array}{l}4 \text { atays } \\
21 \text { dgyos }\end{array}$ \\
\hline & $=$ & $=$ & (3) & 5 & Slon. & 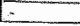 & Stgrn & & $\therefore$ & $\therefore$ \\
\hline
\end{tabular}

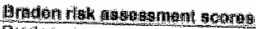

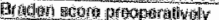

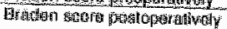

\section{Methodological issues}

Some methodological details should be addressed to interpret and compare the study results. All authors report inclusion and exclusion criteria to the studies. Kemp et al. (1990), Jerusum et al. (1996) and Pokorny et al. (2003) report that patient approval for study inclusion are not needed because the study focused on refining routine nursing assessment and did not alter patient care. Stordeur et al. (1998) didn't report why patient approval was not an inclusion criteria. The 
sample sizes vary from 36 patients in the pilot study of Jerusum et al. (1996) to 351 patients in the study of Pokorny et al. (2003). All samples were related to a defined sampling time except in the study of Kemp (1990) which did not report about the reason for sample size. Possible influences to the samples deriving from the time in which the studies were carried out are not mentioned. Apart from pressure ulcer occurrence, none of the variables under control is observed in all studies (table 2). The skin assessment instrument by the International Association for Enterostomal Therapy (Irvine 1987) which is used in two studies (Kemp et al. 1990, Papantonio et al. 1994) defines grade 1 pressure ulcers as 'erythema that did not disappear within 30 minutes of pressure relief'. The skin assessment toof of Bergstrom (Bergstrom 1989) used in the study of Pokorny et al. (2003) defines grade 1 pressure ulcer as 'redness that does not disappear for 24 hours after pressure is relieved'. These time aspects are different to the 4stage scale from the Wound, Ostomy and Continence Nurses Society (1987), and the classification system by the National Pressure Ulcer Advisory Panel (1989) where grade 1 is in whole defined as non-blanchable erythema. Stordeur (1998) excluded grade 1 pressure ulcers from the study. The differences in the classification systems and excluding of a type of pressure ulcer induces comparability restrictions of the results. Pre- and postoperative skin assessment was carried out in all studies except in the study of Jerusum et al. (1996) who began with the skin assessment after surgery. Skin assessment points vary considerably from admission (Stordeur et al. 1998) to 10 days after surgery procedure (Kemp et al. 1990). The more the assessment points the more the possibility to observe pressure ulcers, especially grade 1 . The reported usual preventive care for the patients included in the studies varies between the institutions. Papantonio reports that patients were initially placed on the standard hospital mattress. If the nurses felt that a patient was at higher risk than a fourinch eggcrate or static air mattress were used. The standard bed configuration in the study of Jerusum contains a polyurethane foam mattress replacement. As postoperative preventive measures Lewicki et al. (1997) observed postoperative turnings. Pokorny et al. (2003) implemented a skin care intervention program. Kemp (1990), Lewicki (1997) and Stordeur (1998) did not report about the standard preventive measures. The preventive care influences the development of pressure ulcers and furthermore the results to significance of special risk factors in the population under study. Univariate and discriminant analysis procedures which are used vary between the studies but they are suitable to analyse the data under observation. 


\section{Conclusion and discussion}

Compressive and shearing forces and their intensity and duration are described as essential factors in pressure ulcer development (Defloor 1999). One would expect that time on the OR table would be significantly associated with pressure ulcer development in all evaluated studies. But only in the studies of Kemp et al. (1990) and Papantonio et al. (1994) was OR time found to be a significant risk factor. Apart from time on the OR table, more information about use of preventive overlays on the OR table would have been necessary, because a pressurereducing overlay may influence pressure ulcer development and hence the related significance of the time on the OR table. Papantonio (1994) and Stordeur (1998) report a viscoelastic polymer pad (Action product Inc.) on the OR table with an additional piece of one-inch eggcrate foam under the sacrum in Papantonios study. In Lewicki's study (1997) a special leg positioner was used, and Kemp reports use of a 3-inch foam pad for the patient's head and an air donut for the buttocks. Tissue tolerance for pressure is clearly influenced by the patient's age. In the studies evaluated here, the older the patient, the greater the risk to develop pressure ulcers. Further, reduced albumin level and corticosteroid medication seems to have an impact. Most indicators reflect the influence of tissue tolerance for oxygen. Body temperature management, hypotension and comorbidities that influence oxygen supply prove to be relevant indicators. Interestingly, ECC was only significantly related to pressure ulcer development in the study of Kemp (1990). Body build, e.g. the body mass index, and smoking were not found to be significant.

Many risk indicators described in the theoretical model were not included in reported studies: maceration, friction, tissue mass, dehydration, vitamin $\mathrm{C}$ deficiency and stress. The preoperative risk for pressure ulcer development was low. This may be due to the normally good condition of patients undergoing cardiac surgery. The postoperative assessment identifies the risk clearly. These results reflect the restricted health status at this time'. Except in Kemp's study, all Braden risk assessment scores were significantly associated with pressure uicer development.

The older patient with diseases that influence the oxygen supply in combination with the special demands of temperature and circulation regulation during the cardiac surgical procedure is at risk for pressure ulcer development. Figure 2 illustrates the focal critical points. 


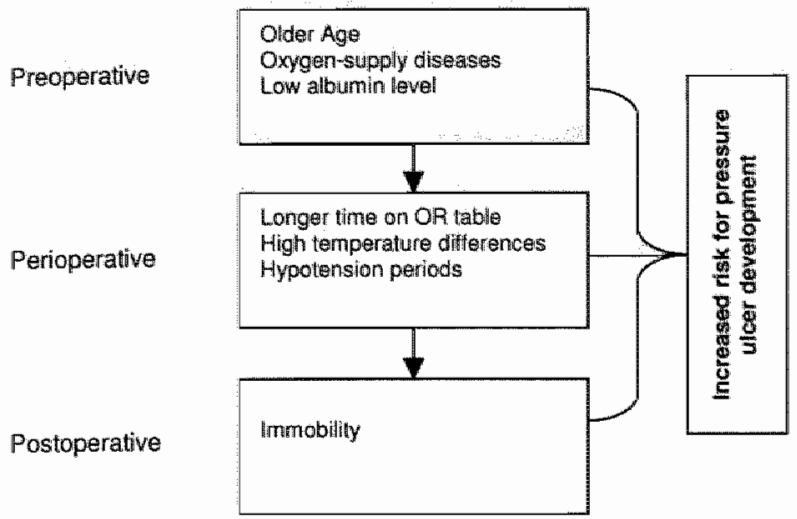

Figure 2

The focal critical points for pressure ulear dovelopment in cardiac surgery

This conclusion must be seen against the background of six studies into risk indicators in this special population, notwithstanding the differences in study inclusion criteria, in variables under study, in the skin assessment instruments and points, in included pressure ulcers (Stordeur didn't include grade 1 pressure ulcer) and in statistical procedures. Hence a direction for risk indicators in the cardiac surgery population can be indicated.

\section{Recommendations for practice and research}

Although studies regarding risk indicators for pressure ulcer development in the cardiac surgery population are few, some recommendations may be advanced. Prevention measures should be aimed at supporting tissue tolerance for pressure and tissue tolerance for oxygen since these are the significant risk indicators in this population. In this light one should assist the normality through

- sensitive temperature management during surgery procedure: normothermic ECC ( $>33^{\circ} \mathrm{C}$ body core temperature) were possible, maximum temperature gradient between $10-15^{\circ} \mathrm{C}$ during cooling and rewarming using hypothermic ECC (The warm heart investigators 1994, Mora et al. 1996),

- sensitive bllood pressure management,

- normalization of the albumin level,

- attention to the patient's age and diseases present (diabetes mellitus, renal insufficiency, cerebrovascular disease). 
These measures should be additional to pressure relieving devices on the OR table and, postoperatively in bed, a defined minimum frequency of postoperativie turning and early mobilization after the surgical procedure.

Further research is necessary to support the findings in the population studied. For example, time on the $O R$ table in combination with pressure relieving devices, differences in temperature and blood pressure management and differences in mobility activities after surgery should be examined scientifically in combination with pressure ulcer occurrence. 


\section{References}

Alman RM et al. Pressure sores among hospitalised patients. Ann Internal Med 1986;105:337. 342

Bergstrom N, Braden BJ. A conceptual schema for the study of the etiology of pressure sores. Rehab Nurs 1987; $12(1): 8-12,16$

Bergstrom N, Braden BJ, Laguzza A, Holman V. The Braden scale for predicting pressure sore risk. Nurs Res 1987;36(4):205-10

Bergstrom N. Pressure sore data collection questionnaire: skin assessment tool. 1989. Available at http//www.bradenscale.com/skinassess.htm. Accessed December 30, 2004

Bours GJJW. Halfens RJG, Huijer Abu-Saad $\mathrm{H}_{*}$ Grol RTPM. Prevalence prevention and treatment of pressure ulcers: Descriptive study in 89 Institutions in the Netherlands. Res Nurs Health 2002 ;25(2):99-110

Charlson ME et al. A new method of classifying prognostic comorbidity in longitudinal studies: Development and validation. J Chron Dis 1987;40(5):373-83

Clark M, Cullum N, Crow RA $A_{y}$ Chapman RG, Farrer S, Fabland LB. Prevention of pressure sores: aspects of the identification of patient vulnerability and the effectiveness of preventative interventions. Finall Report to the Department of Health: Nursing Practice Research Unit; 1991

Cuddigan J, Ayello EA ${ }_{n}$ Sussman C, Baraoski S. Pressure Ulcers in America: Prevalence, Incidence, and Implications for the Future. Reston, Virginia: NPUAP; 2001

Defloor T. The risk of pressure sores: a conceptual scheme. J Clin Nurs 1999;8:206-16

Deutsches Netzwerk für Qualitätsentwicklung in der Pflege (DNQP) (Hrsg.). Expertenstandard Dekubitusprophylaxe in der Pflege, Entwicklung - Konsertierung - Implementierung; 2002. ISBN: 3-00-009033-9

DOH. Pressure sores - a key quality indicalor: a guide for NHS purchasers and providers. Lancashire: BAPS Health Publications Unit: 1993

Effective Health Care. The prevention and treatment of pressure sores. Effect Health Care $1995 ; 2(1): 1-16$

Goldstone LA, Goldstone J. The Norton score: An early warning of pressure sores? J Adv Nurs $1982 ; 1: 419-26$

Hibbs P. The economics of pressure ulcer prevention. Decubitus 1988;1(3):32-38

Imman KJ, Sibbald WJ "Rutledges FS, Clark BJ. Clinical utility and cost effectiveness of an air suspension bed in the prevention of pressure ulcers. JAMA 1993;269:1139-1143

Irvine CA, editor. Standards of care: Dermal wounds: Pressure sores. International Association for Enterostomal Therapy; 1987

Jerusum $J_{0}$ Joseph $K$, Davis $J_{M}$ suki R. Balloons, beds and breakdown. Crit Care Nurs Clin North Am 1996;8:423-40

Kemp MG et al. Factors that contribute to pressure sares in surgical patients. Res Nurs Health 1990;13:293-301

Knaus WA et al. APACHE Il: A severity of disease classification system. Crit Care Med $1985 ; 13: 818$ 
Lewicki Lul al. Patient risk factors lor pressure ulcer during cardiac surgery. AORN J 1997;65 $(5): 933-42$

Mara $\mathrm{Cr}$ et al. The affects of temperature management during cardiopulmonary bypass on neurologic and neuropsychologic outcomes in patients undergoing coronary revascularization. $J$ Thrac Cardiovase Surg 1996;112:514-522

National Pressure Ulcer Advisory Panel. Pressure Ulcers: Consensus Development Conference Statement. West Dundee, IL: S-N Publications, 1989

Papantonio CT, Wallop KB, Kolodner KB. Sacral ulcers following cardiac surgery: Incidence and risks. Adv Wound Care 1994;7:24:26

Pokorny ME "Koldjeski D, Swanson M. Skin Care Intervention For Patients Having Cardiac Surgery. Am J Crit Care 2003;12:535-544

Schoonhoven L, Defloor T, Grypdonck MHF. Incidence of pressure ulcers due to surgery. J CLIN NURS 2002;11(4):479-87

Stordeur $S_{\text {"Laurent }} \mathrm{S}$, D Hoore $W$. The importance of repeated risk assessment for pressure sores in cardliovascular surgery. J Cardiovasc Surg 1998;39(3):343-49

The warm heart investigators. Pandomised trial of normothermic versus hypothermic coronary bypass surgery Lancet 1994:343:559-563

Wound, Ostomy \& Continence Nurses Society. Standards of Care: Patients with Dermal Wounds: Pressure Ulcers. Calif: Costa Mesa; 1987 


\section{CHAPTER 3}

The Effect of the "Failure Mode and Effects Analysis" Model on Pressure Ulcer Incidence in

Cardiac Surgery

Feuchtinger J, Halfens RJG, Dassen T, De Bie R (2005) submitted for publication 


\section{Abstract}

Objective: The Failure Mode and Effects Analysis (FMEA) model is "a systematic process for identifying potential design and process failures before they occur, with the intent to eliminate them or to minimise the risk associated with them ${ }^{\text {"t }}$ (FMEA 2004). Pressure ulcer prevention is a continuous challenging task in health care organisations, for they represent painful adverse events for patients and are a cost burden for health care institutions. It is reported that pressure ulcer therapy costs between $\$ 5000$ and $\$ 40,000$ per patient (Allman et al. 1986, Imman ef al. 1993, Bours et al. 2002). The FMEA offers an additional approach to improve pressure ulcer prevention management. In this study the effectiveness of the FMEA as a failure preventive method in pressure ulcer prevention and pressure ulcer incidence is studied in the cardiac surgery population.

Design: A longitudinal descriptive design with repeated up-dating of the FMEA and repeated measurements of pressure ulcer occurrence in the Department for Cardiovascular Surgery in the University Hospital Freiburg, Germany.

Main outcome measures: Reduction of the risk priority numbers (RPN) in the FMEA and the pressure ulcer incidence. The RPN is the mathematical product of severity, likelihood of occurrence and likelihood of detection of failure modes in pressure ulcer prevention.

Results: The FMEA over three years shows a decrease in the RPNs in most of the failure modes and a reduction of the pressure ulcer incidence by $15 \%$.

Conclusion: The Failure Mode and Effects Analysis model is an effective quality management tool to improve pressure ulcer prevention management in cardiac surgery. 


\section{Introduction}

Pressure ulcer prevention continuously challenges health care organisations. Guidelines like the policy of the Agency for Health Care Policy and Research (Panel for the Prediction and Prevention of Pressure Llcers in Adults 1992), the prevention guidelines of the European Pressure Ulcer Advisory Panel (EPUAP 2004) or the National Expert Guideline for Pressure Ulcer Prevention in Germany (DNQP 2002) are leading activities in pressure ulcer prevention management. Besides the implementation of pressure ulcer prevention programmes, daily practice presents many hazards concerning pressure ulcer prevention. To assess risks and failures quality management offers several tools; e.g. the 3F-Method (3F-Method 2002, 2004), the Fault Tree Analysis (Center for System Reliability 2004) or the Failure Mode and Effects Analysis (FMEA 2004). The FMEA enables an organisation to grasp the existing experience and knowledge about failure modes, failure connections and quality influences and make this knowledge available for a continuous improvement process. This study investigates the effectiveness of the FMEA as a failure preventive method in pressure ulcer prevention and the pressure ulcer occurrence in the cardiac surgery population in a German University Hospital.

\section{Theoretical background}

Knowledge of special risks that lead to pressure ulcer development in specific populations like cardiac surgery patients (Kemp et al. 1990, Papantonio et al. 1994, Jerusum et al. 1996, Lewicki at al 1997, Stordeur et al. 1998) and the use of an evidence-based prevention policy (Panel for the Prediction and Prevention of Pressure Ulcers in Adults 1992, DNQP 2002, EPUAP 2004) are mandatory to enable an effective prevention management programme. Nevertheless, daily practice challenges the effectiveness of pressure ulcer prevention. The Failure Mode and Effects Analysis (FMEA) is a method to grasp daily risk and failure modes and offers an approach to modify them. The FMEA is "a systematic process for identifying potential design and process failures before they occur, with the intent to eliminate them or minimise associated risks" (FMEA 2004). It offers methodological advantages (e.g. universal use, standardised and simple documentation), technical advantages (e.g. improvement on the object of interest) and psychological-organisational advantages (e.g. know-how transfer) (NedeB \& Nickel 1993, Tlach 1993). As the FMEA is a standardised quality management method, it can be used in any setting, e.g. in a health care organisation and in the manufacturing industry as well. Moreover, in general it 
results in an increase of quality awareness, increased productivity and decreased costs.

The FMEA is an inductive approach. It was first used in the United States Military as a reliability evaluation technique to determine the effect of system and equipment failures. The process of interest, $6 . \mathrm{g}$. the pressure ulcer prevention management, is analysed in its process elements followed by assigning the functions to the process elements. Consequently, possible malfunctions and failure modes are identified. In a risk grading process the relevance of a failure mode and the probability of occurrence and discovery are calculated. Finally, improvement measures and the accepted residual risk priority number are stated. The FMEA should be updated continuously to see the development in the continuous improvement process. The FMEA elements and the process are shown in figure 1.

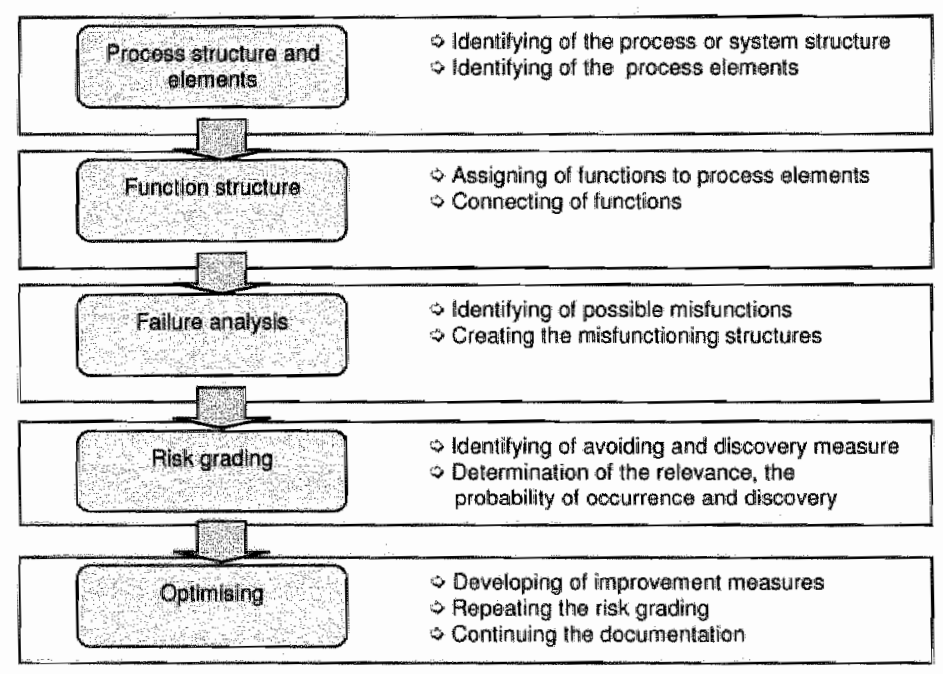

Figure 1 FWEA aloments and process

The basis of the FMEA process is a multidisciplinary expert team. Each step is initiated by these experts.

\section{Methods}

\section{Design}

To study effectiveness of the influence of FMEA in pressure ulcer occurrence, a longitudinal descriptive study with implementation of the FMEA and repeated measures of pressure ulcer incidence was chosen (Polit \& Hungler 1999). 


\section{Sample}

To assess the pressure ulcer occurrence patients were admitted to the study when they were scheduled for cardiac surgery procedures. In five four-week periods 387 patients (in each period $60-90$ patients - see figure 3 ) were assessed for pressure ulcer occurrence.

\section{Instruments}

For pressure ulcer grading the pressure ulcer classification system as recommended by the European Pressure Ullcer Advisory Panel (EPUAP 2004) (table 1) was used.

Table i Pressure ulcer classification system by EPUAP (2004)

Grade 1 Non-blanchable erythema.

Grade 2 Partial-thickness skin loss or damage involving epidermis andior blister and shallow ulcer.

Grade 3 Full-thickness skin loss involwing damage or necrosis of epidermis and/or dermis.

Grade 4 Full-thickness skin loss involwing damage or necrosis of epidermis and/or dermis extending to undertining muscle, bone, tendon ar capsule.

\section{Intervention}

The research was divided into two parts; the first part being the construction of the FMEA to detect failure modes and their effects in the pressure ulcer prevention management and the second part the data collection of pressure ulcer occurrence. Below the implementation of each FMEA element (figure 1) in the pressure ulcer prevention management is presented.

\section{The multidisciplinary expert team}

At the core of the FMEA is the multidisciplinary expert team, use of which has been described as a method to reach a scientific basis in a subject of interest (Fehring 1986). In pressure ulcer prevention management the failure modes and their effects have not yet been described and, moreover, they vary across institutions. Especially in such situations where not enough structured information is available, the expert group is an accepted first step in the scientific process. The members of the multidisciplinary expert team in this project were representatives from each unit through which the patient passes from admission to discharge. The criteria for the experts were specified as: experience in his/her field of work and with authority for orders to pressure ulcer prevention 
management in the particular work group. Additionally, specialists in the pressure ulcer prevention management, in nursing research and quality management were members in the expert group. The following experts were included: Nurses (pre- and postoperative care, intensive care, operating room, anaesthesia), physicians (surgeon, anaesthetist), a clinical nurse specialist, a nurse scientist and a quality manager.

The expert team consisted of nine individuals. The leader was a quality manager with experience in the use of the FMEA. On the basis of the prevention guidelines for pressure ulcer prevention and the special risks for pressure ulcer development in patients undergoing cardiac surgery procedures as reported in the literature, the expert panel constructed the FMEA step by step.

\section{Process elements}

As process structure for the pressure ulcer prevention management, the expert team chose the main stations that the patient passes from admission to discharge:

- Admission and preoperative care;

- Operating room;

- Intensive care;

- Postoperative care and discharge.

The first process elements are admission and preoperative care. Here the first steps in pressure ulcer prevention like risk assessment and the individual care plan are carried out. In the second process element, the operating room, the patient is in a critical situation for the development of a pressure ulcer because he/she is lying in one position over a longer time period. Process elements three and four, intensive care and postoperative care and discharge, require in each situation the planning and carrying out of the prevention measures for each individual. Each Process element contains risks and failure modes concerning pressure ulcer prevention management.

\section{The functions and the function structure}

Each process element was subdivided in functions which are considered elementary in pressure ulcer prevention. The stated functions are the result of a thorough evaluation of the prevention guidelines (Panel for the Prediction and Prevention of Pressure Ulcers in Adults 1992, the German National Expert Guideline for Pressure Ulcer Prevention 2002, EPUAP 2004) and the special risks of cardiac surgery patients for pressure ulcer development according to the 
literature (Kemp et al. 1990, Papantonio et al. 1994, Jerusum et al. 1996, Lewicki at al 1997, Stordeur et al. 1998, Pocorny 2003). Each function contains the risk for a failure. Table 2 shows the concepts identified as relevant by the expert team for failure modes in the pressure ulcer prevention management in the Department.

Table 2 The process ellements and the Enction structure

\begin{tabular}{|c|c|c|c|}
\hline $\begin{array}{l}\text { Admission and } \\
\text { preoperative care }\end{array}$ & Operating Room & Intensive care & $\begin{array}{c}\text { Postoperative care } \\
\text { and discharge }\end{array}$ \\
\hline $\begin{array}{l}\text { - Bisk assessment } \\
\text { - Bed configuiration }\end{array}$ & $\begin{array}{ll}\text { - } & \text { Information } \\
\text { - } & \text { Cathablate } \\
\text { - } & \text { Disinfection } \\
\text { - Temperature } \\
\text { - Waming device } \\
\text { - Electrodes }\end{array}$ & $\begin{array}{ll}\text { - } & \text { Anformation } \\
\text { - } & \text { Bisk assessment contiguration } \\
\text { - Mositioning } \\
\text { - Mobilisation }\end{array}$ & $\begin{array}{l}\text { - Information } \\
\text { - Bisk assessment } \\
\text { - Bed conflguration }\end{array}$ \\
\hline
\end{tabular}

\section{The risk grading}

The risk grading process begins with the description of planned measures for failure detection and prevention followed by the risk calculation which results in a risk priority number. The risk priority number is the mathematical product of severity, occurrence and detection rating.

$$
\text { RPN = Severity (S) } \times \text { Occurrence (O) } \times \text { Detection (D). }
$$

Severity assesses how serious the effect of the potential failure mode is on the patient. Occurrence assesses the likelihood that a particular cause will happen and result in a failure mode during the intended process. Detection establishes the likelihood that the current controls will detect the cause of the failure mode or the failure mode itself, thus preventing the failure from reaching the patient. Severity, occurrence and detection have to be adopted to the process or system of interest. The suggested evaluation criteria and the ranking system of severity, occurrence and detection in the pressure ulcer prevention management are shown in table 3 . 
Tabu 3 FHE - rigk arading in pressure woer prewenton management

\begin{tabular}{|c|c|c|c|}
\hline hank & Soverly (S) & occurrence $(\mathrm{O})$ & Detection (D) \\
\hline H & $\begin{array}{l}\text { None } \\
\text { The fallore doesn l resull in } \\
\text { a Pu" }\end{array}$ & Remete, iaifure is wnlikely & Almost certain \\
\hline 2 & Very minar & Wery low: frequency $1 / 200$ patients & Very high theelhood \\
\hline 3 & Minor & Viory law frequency $1 / 100$ patients & High hellihood \\
\hline 4 & Very low & Low frequency 1 loo patients & Moederate thigh \\
\hline 5 & Low & Low: frequency $1 / 50$ patienits & Moderate likelihood \\
\hline E & Moderate & Hoderate: frequancy $1 / 40$ patients & Low likelinood \\
\hline 7 & Whigh & Moderate: frequency $1 / 30$ patients & Very low likellihood \\
\hline$g$ & Vory high & Hight frequency i/20 patients & Remote lkelihood \\
\hline b & $\begin{array}{l}\text { Extremely high } \\
\text { The falure residus with an } \\
\text { oxtremely high likelihood in } \\
\text { a PU* }\end{array}$ & High: frequency $1 / 10$ patients & Very remote bikefithood \\
\hline 10 & Extremely high & Vary high: frequency $1 / 2$ pationts & Almost impossible \\
\hline
\end{tabular}

- PU $=$ pressure uhar

The risk priority number is used to place priority on items that require additional quality improvement activities. The first RPN-calculation was done by expert consensus, averaging individuals best estimates. In the following an additional internal monitoring with checklists was established to objectify the RPNcalculation. The experts also stated an accepted residual RPN which should be as low as reasonable possible. Two examples of functions and their risk grading from June 2003 should show the risk grading process:

\section{Example 1}

Process element:

Function:

Pollentital lailure:

Potental failure effoct:

Causs:

Actual measures:

Pisk gradling:

Accepted AIPN:

Responsible:
Admission and preoperative care

Pisk assessment by the modified Norton scale

Not cartied out

Incorrect prevention measures

Time restraints; unaccepted by nurses for mobile, independent patients

Education to risk assessment

Severity (S):

Probability of occurrence $(O)$ :

Likelhood of detection (D):

Risik priority number (RPN):

$\begin{array}{lr}\text { Very high } & 8 \\ \text { High } & 8 \\ \text { High likelihood } & 3 \\ 8 \times 8 \times 3 & 192\end{array}$

8

Recommended measures: Accepting the clinical decision without an assessment by the modified Norton scale to a pressure ulcer risk carried out by a compettent nurse at the admission; risk assessmant with the modifled Norton scale in case of a calculated tisk by the clinical decision; documentation of the risk assessment method and resulit

Severity $(S)$ :

Probability of occunrence (O):

Likelihood of detection (D):

Pisk prionity number (RIPN):

Very high

Very llow

High thellihood

$3 \times 8 \times 3$

100

Ward Head Nurse 


\section{Example 2}

Process element:

Function:

Cause:
Potential failure:

Potential failure effect:

\section{Intensive Care Unit}

Intormation to the ICU staff to the patients risk for pressure ulcur development or an existing pressure uttcer

Lack of information about pressure ulcer rilsk resulting from special surgical procedures: lack of information to a present pressure ulcer

Incorrect pressure reducing device in the ICU bed, incorrect care plan, deterioration of an exisiting pressure ulcer

- No information from OR staff to ICU nurses about special surgical procedures of

- No information from OR staff to ICL nurses to an existing pressure ulcer

- The handover of the patient to the ICU nurses is done by OR staff membersi which are not informed about an existing pressure ulcer

- Patient can it be turned enough for skin inspection at the handover to the ICU nurses

Actual measures: Information at the handover to a preoperative pressure uleer and a special surgical procedure which need special prevention measures; skin inspection at the handover

Risk grading:

Severity (S):

Probability of occurrence $(\mathrm{O})$ :

Likelihood of detection (D):

Risk priority number (APN):

$\begin{array}{lr}\text { Very high } & 9 \\ \text { High } & 8 \\ \text { Maderate likelihood } & 5 \\ 8 \times 9 \times 5 & 360\end{array}$

5

Recommended measures: - One hour before finishing the operation the second OR murse calls the ICU if an unplamned special surgical procedure was carried out to give the ICU staff enough time to prepare the patients bed with a correct presisure ullcer prevention device

- The documentation site for a preoperative existing PU is standardised and transparentt to all $1 \mathrm{CU}$ nurses

- II the patient can't be turned at the handover for skin inspection the first turning and skin inspection has to be carried out within 30 minutes after arriving at the $\mathrm{ICU}$

Pesidual RPN:

Severity (S):

Probability of occurrence (O):

Likelihood of detection (D):

Pisk prionity number (RPN):

Very high

Low

Maderate likelihood

$4 \times 9 \times 5$

Accepted RPN:

200

Risponsible:

OF Head Nurse

\section{Optimisation of pressure ulcer prevention management}

To optimise pressure ulcer prevention management continuous data on failures and pressure ulcer occurrence have to be collected. Although data collection is time-consuming, it is nevertheless an essential element in the FMEA. An objective database is just as necessary as the multidisciplinary expert team or the function statement to reach effectiveness of the FMEA for pressure ulcer prevention.

In the Department for Cardiovascular Surgery the essential data to be collected were the occurrence of failures as stated in the function structure and the occurrence of pressure ulcers. For the systematic data collection of failures 
checklists were used. Data collection of pressure ulcer occurrence was carried out by the nurses in daily practice under supervision of a nurse researcher. Data on pressure ulcer occurrences were collected five times during four weeks (from January 2001 till December 2003) interspersed with updating of the FMEA (see table 4).

Table 4 FMAA and pressitro uleer data collection

\begin{tabular}{|l|l|l|l|l|l|l|l|l|}
\hline & $\begin{array}{l}\text { Jan } \\
2001\end{array}$ & $\begin{array}{l}\text { Jan } \\
2002\end{array}$ & $\begin{array}{l}\text { May } \\
2002\end{array}$ & $\begin{array}{l}\text { Oct. } \\
2002\end{array}$ & $\begin{array}{l}\text { Dec } \\
2002\end{array}$ & $\begin{array}{l}\text { Apr } \\
2003\end{array}$ & $\begin{array}{l}\text { Jun } \\
2003\end{array}$ & $\begin{array}{l}\text { Dec } \\
2003\end{array}$ \\
\hline FMEA & & & $x$ & & $x$ & & $x$ & \\
\hline $\begin{array}{l}\text { Pressure ulcer } \\
\text { Occurrence }\end{array}$ & $x$ & $x$ & & $x$ & & $x$ & & $x$ \\
\hline
\end{tabular}

\section{Results}

\section{Patient data}

In each of the five four-week periods for pressure ulcer data collection between 63 and 91 patients were assessed. Mean age for the total of 387 patients included was 66 years (SD 11.7 years) with a median age of 67.5 years. All patients were undlergoing open heart surgery procedures.

\section{The FMEA}

Figure 2 shows the results of the first FMEA and the two FMEA-updates on the functions considered since the beginning in May 2002. Results of risk-loaded functions which lead to failures and their changing in the risk priority numbers over the last two years are presented. 


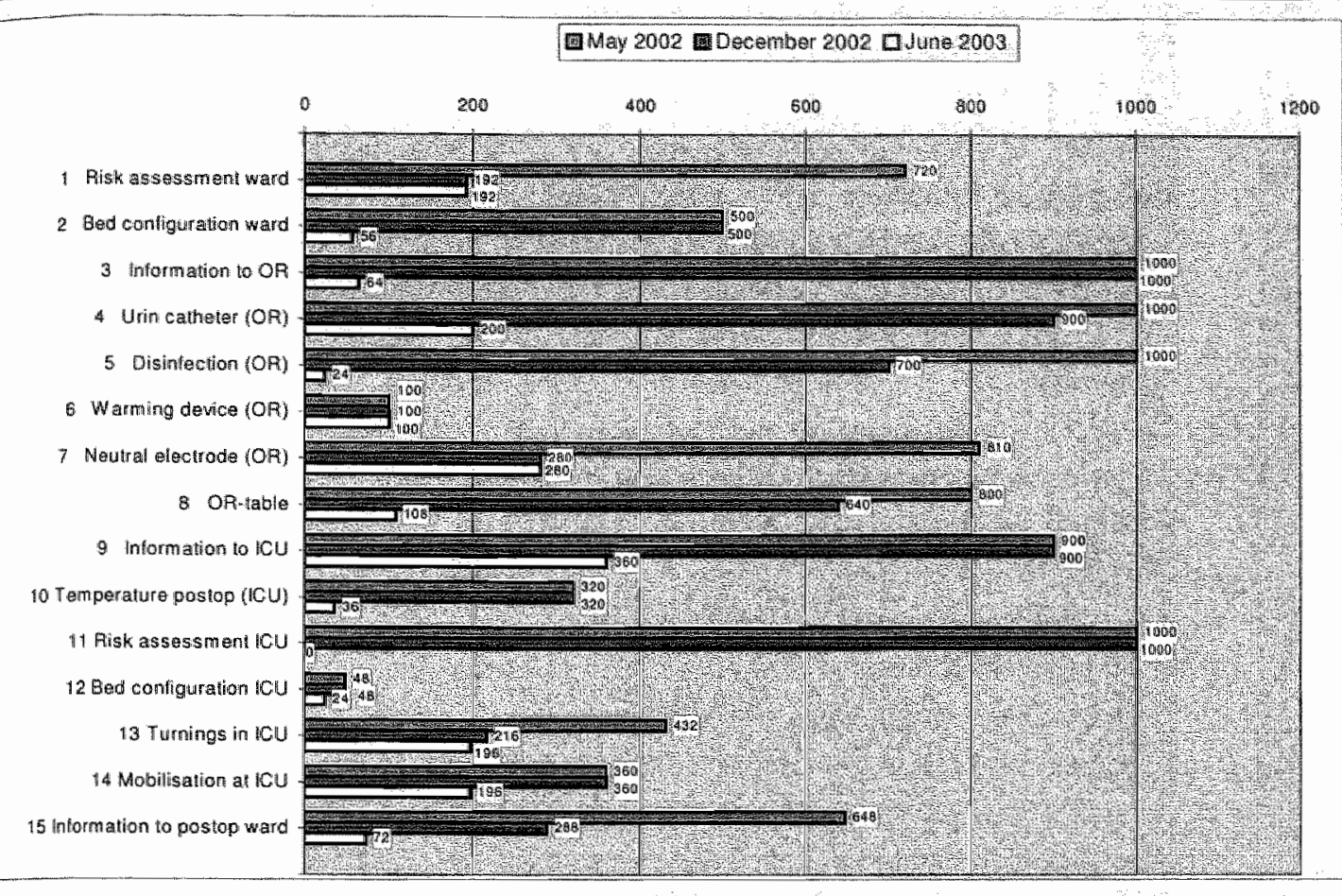

Figure 2 Functions and risk priority numbers

The FMEA shows a reduction of the risk priority numbers in all functions except the warming device. Explanations for the improvement of functions and the accepted residual risk are as follows:

1. Risk assessment ward: RPN dropped from 720 to 192 , mainly because of education for nurses and control of documentation. As the accepted residual RPN is stated with 100 by the expert group further improvernent measures are necessary (see example 2).

2. Bed configuration: RPN dropped from 500 to 56 due to new special pressurerelieving mattresses. The use of air-fluid overlays or mattresses was standardised. Accepted residual risk: 50

3. Information to OR: RPN dropped from 1000 to 64 because the lack of information about pressure ulcer risk or a present pressure ulcer from the preoperative ward to $\mathrm{OR}$ was compensated through a skin assessment together with the OR nurse at the moment of transfer of the patient to the OR. Accepted residual risk: 100

4. Urine catheter: RPN dropped from 1000 to 280 because for bladder catheterisation an additional disposable bed protector which was carefully removed after this intervention was used. Accepted residual risk: 200 
5. Disinfection OR field: RPN dropped from 1000 to 24 because the surgeons responsible for the disinfection of the $O R$ field were informed about the problem of too wet a disinfection. The fluid can run under the patient, developing a moisture reservoir and, in combination with pressure, leading to pressure ulcer (or incontinence damage). When the patient left the OR-table, clothes were checked for signs of disinfection fluid and a positive result was given back to the surgeon. Accepted residual risk: 100

6. Warming device: RPN did not drop down because the hardness of the warming device used on the OR table had not been solved yet. Tests of alternative products were not satisfactory so far. Accepted residual risk: 0

7. Neutral electrode: RPN dropped from 810 to 270 because the neutral electrode was positioned at non-pressure-exposed parts of the body but near the OR field. Accepted residual risk: 200

8. OR table: RPN dropped down from 800 to 216 because the $O R$ table was now covered with a preventive device. In addition, the number of clothes was reduced to prevent the possibility of folds. Accepted residual risk: 100

9. Information to ICU: RPN dropped from 900 to 720 . At transfer from OR to ICU the lack of information about pressure ulcer risk resulting from special surgical procedures or a present pressure ulcer should be compensated through a skin assessment at the hand-over of the patient from the OR-staff to the ICU nurses. But many patients cannot be turned enough for a correct skin assessment. This failure mode needs a new intervention. Accepted residual risk: 200

10. Postoperative temperature: RPN dropped down from 320 to 36 . As a result of the temperature management in the OR, the first temperature at ICU should be equal to the preoperative temperature. Accepted residual risk: 50

11. Risk assessment ICU: RPN dropped down from 1000 to 0 . The pressure ulcer risk assessment through a risk assessment instrument was not implemented in ICU. A study of risk assessment instruments in the cardiac surgery ICU in 2002 did not give satisfying results with the Braden scale (Bergstrom et al. 1987b), the modified Norton scale (Bienstein et al. 1991) and the 4-factor model. For example, the Braden scale stated that $\geq 80 \%$ of patients in the first four days after the surgery procedures are "at risk". According to this result, all ICU patients were considered as 'at risk'. The nurses are regularly trained in noting risk factors, making skin assessment and taking preventive measures.

12. Bed configuration ICU: RPN dropped from 48 to 24 . This RPN was low due to new special pressure-relieving mattresses and the standardised use of airfluid overlays or mattresses. Accepted residual risk: 30 
13. Turnings in ICU: RPN dropped down from 432 to 192 . The turning intervals of patients at the ICU were standardised. The task was checked at shift changes with the nurse coming on duty. Accepted residual risk: 200

14. Mobilisation in ICU: RPN dropped down from 392 to 192 according to standardised mobilisation procedures. The task was checked at shift changes with the nurse coming on duty. Accepted residual risk: 200

\section{The pressure ulcer occurrence}

The pressure ulcer incidence data are shown in figure 3 .

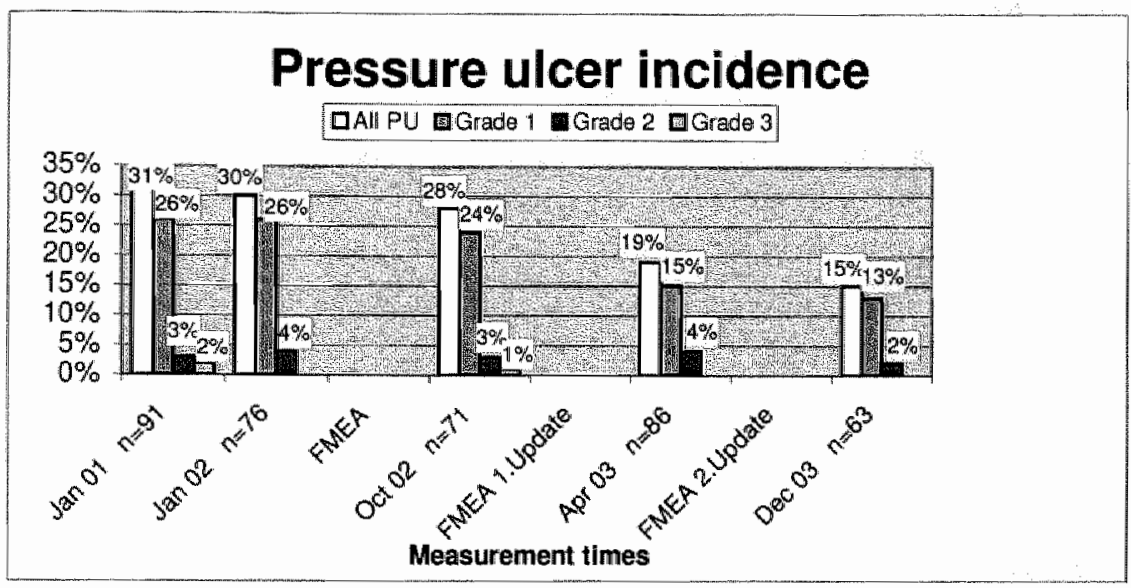

Figure 3 Pressure ulcer incidence

No relevant decrease in pressure ulcer occurrence can be seen before FMEA 1. A remarkable reduction can be seen after the first FMEA-update. In any data collection period $\leq 5 \%$ of new pressure ulcers were at grade 2 . The pressure ulcers of two patients in 2001 and of one patient in 2002 progressed from grade 2 to grade 3 during the hospital stay. This did not occur in 2003.

\section{Discussion}

The FMEA and its improvements in the pressure ulcer prevention management resulted in a pressure ulcer reduction from $31 \%$ to $15 \%$ during three years. Additionally, the risk priority numbers of most failure modes and risks decreased. Nevertheless, some remarks concerning the FMEA-process and its limitations are necessary.

The use of an expert group to get a valid scientific basis on a special subject is not without hazards. First, the definition of an expert is unclear. Fehring (1986) 
stated that ${ }^{\text {}} . .$. an expert in the validation model to identify nursing diagnosis should be at a masters level with a defined clinical expertise. The strength of the diagnostic content validity rests on the expertise of the raters." One can transfer this remark to the expert approach in the FMEA. The FMEA method itself recommends nothing to the expert definition except that the group should represent the field of interest.

Second, based on special risk factors and prevention guidelines the experts specified functions and function structures. This means that each step in the prevention management which contains failure modes, e.g. to state a risk assessment, use of pressure reducing devices or control of nutrition intake, was checked for the relevance in the department and added to the function structure. In this step of the FMEA, threats can occur by missing relevant functions. A method to gain more strength is to include every function which contains the possibility for failures and to exclude it if no relevance is shown by the risk grading. For example, in the project presented here the nutrition intake was never included in the function structure because it was not stated as risk or failure mode in the prevention management. It is necessary to consider each failure mode named by the experts and ensure that the relevance is checked through an objective method, e.g. checklists.

Third, the risk grading is a part in the FMEA which contains the possibility to weaken the results. The rating system as shown in table 4 is developed for the military and the manufacturing industry. To rate severity, occurrence and detection of a risk or a failure in pressure ulcer prevention management fully depends an the experts' opinions. An objective occurrence rating is given if data on adverse events, failures and risks are present. In institutions where these data are not collected, expert opinion is a first step to calculate the occurrence rate. The more objective the data is on failures in pressure ulcer management, the more valid the risk grading.

A luther threal to the strength of the FMEA is the data collection of pressure ulcer occurrence. It is reported that pressure ulcer data collected by research assistants are more valid than data collected by nurses in daily practice. In this stucy pressure uicer data were assessed by nurses in daily practice. The nurses were supervised by the quality manager and the nurse researcher. Due to resource constraints supervised data collection on pressure ulcer incidence were restricted to five pericds. In daily routine pressure ulcers are reported as adverse events. Here the possibility of false negative results has to be kept in mind.

Pressure ulcer occurrence in the cardiac surgery population is reported to be as high as $29.5 \%$ (Stordeur et al. 1998). The reduction of pressure ulcers to $15 \%$ in this study is a result which reflects a continuous improvement process. 
Especially the fact that no pressure ulcer deteriorated to grade 3 or 4 in 2003 and that of all pressure ulcers the grade 2 type were $\leq 5 \%$ over the three-year period is a positive outcome.

Not included in data collection were staff conditions such as workload or absenteeism which can influence pressure ulcer prevention management and occurrence of failures.

A major limitation to stating causality between FMEA and pressure ulcer decrease is evident through the ongoing discussion of the subject, the continuing education in pressure ulcer prevention, the control over failures and pressure ulcer occurrence. It is not the FMEA that results in pressure ulcer reduction but the prevention methods. The more effective the prevention methods, the less the pressure ulcer occurrence. The FMEA can be used as a part of the prevention management.

Most of the assessed pressure ulcers in this study are grade 1. One could think that it is not really a problem to take care of. The initial problem for the implementation of FMEA in 2002 was been the occurrence of grade 3 pressure ulcers. These pressure ulcers are very painful for the patients, impressively for health care members and cost-intensive. In this light, the implementation of a quality improvement tool like the FMEA is acceptable. The development of grade 3 pressure ulcers in 2002 and 2003 decreased. The FMEA needs resources as does the treatment of pressure ulcers, but the improvement for the patients and the psychological effect in health care members due to a positive outcome is inestimable.

\section{Conclusion}

FMEAs over two years have shown a decrease in the risk priority numbers in functions which are at risk for failure except in the function "warming device", and consequently pressure ulcer incidence decreased. The number of patients observed for pressure ulcers was similar in the different observation periods and no changes in mean age of the patients or surgical procedures were noted. Not included in the data collection were staff conditions such as workload or absence times which can influence pressure ulcer prevention management and the occurrence of failures.

We therefore believe that implementation of FMEA in pressure ulcer prevention management can be successful if the following conditions are met:

- Experts in the expert group represent the process structure, are experienced in their field of work and have authority for orders to pressure ulcer prevention management in the particular work group; 
- Expert opinion is not only experience-based but also relies on a theoretical background and on valid data;

- The process structure represents the field of investigation.

The management has to support a positive failure culture, provide the resources and has to back the experts in the teams who are responsible for a continuous improvement process in pressure ulcer prevention. Data on FMEA and pressure ulcer occurrence over three years show that the FMEA is a tool which can foster improvement in pressure ulcer prevention. 


\section{References}

Allman R.M. et al.: Pressure sores among hospitalised patients. Ann Interna/ Med 105:337-342, 1986

Bergstrom N., Braden B.J., Laguza A., Holman V.: The Braden scale for predicting pressure sore risk. Nursing Research 36:205-210, $1987 \mathrm{~b}$

Bienstein C., et al.: Risikopatienten erkennen mit der erweiterten Nortonskala: In: Dekubitus. Prophylaxe - Therapie. DBfK, 66-74, 1991

Bours G.J.J.W. Halfens R.J.G., Huijer Abu-Saad H., Grol R.T.P.M.: Prevalence prevention and treatment of pressure uicers: Descriptive study in 89 Institutions in the Netherlands. Res Nurs Health 25(2):99-110, 2002

Center for System Reliability: Fault-Tree-Analysis. http://reliability.sandia.gov/index.htm! 10.02 .2004

DNQP (Deutsches Netzwerk für Qualitätsentwicklung in der Pflege) (Ed.): Expertenstandard Dekubitusprophylaxe in der Pflege, Entwicklung - Konsertierung - Implementienung; 2002

EPUAP (European Pressure Ullcer Advisory Panel) httg//www.epuap.arg/glprevention.himl 10.03.2004

EPUAP (European Pressure Ulicer Advisory Panel) hittp:/www.epuap.org/gltreatment.html 10.02.2004

Fehring R.J.: Validating diagnostic labels: standardized methodology. [Book Chapter.

Proceedings] Classification of nursing diagnoses: proceedings of the sixth conference held in $\mathrm{St}$. Louis, MO, April 4-6, 1984 (Hurley ME). C V Mosby Company, 1986, 183-90

FMEA: http:/Www.fmeca.com/ffmethod/identify.htm 10.02 .2004

Halfens R.J.G., Van Achterberg T., Bal R.M.: Validity and reliability of the Braden scale and the influence of ather risk factors: a mulli-centre prospective study. International Journal of Nursing Studies $37: 313-19,2000$

Imman K.J., Sibbald W.J., Rutledges F.S., Clark B.J. Clinical utility and cost effectiveness of an air suspension bed in the prevention of pressure ulcers. JAMA 269:1139-1143, 1993

Jerusum J., Joseph K., Davis J.M., Suki F.: Balloons, beds and breakdown. Crit Care Nurs Clin North Am 8:423-40, 1996

Kemp M.G. et al.: Factors that contribute to pressure sores in surgical patients. Res Nurs Health 13:293-301, 1990

Lewicki L.J. et al... Patient risk factors for pressure ulcer during cardiac surgery. AORN J 65 (5):933-42, 1997

Nedeß C. Nickel J.: FMEA wissensbasiert erstellen. Qualität und Zuverlässigkeit, 38(12):689, 1993

Panel for the Prediction and Prevention of Pressure Ulcers in Adults: Pressure U/cer in Adwits: Prediction and Prevention. Clinical Practice Guideline, Number 3. AHCPF Publication No. 92* 0047. Rockwille, MD: Agency for Health Care Pollicy and Research. Public Health Service, US Department of Heath and Human Services, May 1992

Papantonio C.T., Wallop K.B., Kolodner K.B.: Sacral ulcers following cardiac surgery: Incidence and risks. Adv Wound Care 7:24-26, 1994 
Polit D.F. Hungler B.P... Nursing research: principles and methods. Philadelphia: Lippincott Williams \& Wikins, $1999,6^{\text {th }}$ ed

Stordeur $S$. Laurent $S$. D'Hoore W.: The importance of repeated risk assessment for pressure sores in cardiovascular surgery. J Cardiovasc Surg 39(3):343-49, 1998

Tlach $H_{\text {.. FMEA }}$ ein strategisches Element des Qualitătsmanagement-Systems. Qualităt und Zuverlåssigkeit, $38(5): 279,1993$

3F-Method: http//www mock.cc/3f/risiko htm 10.02.2004

3F-Method: http:/www.oeqs.at/pd/kundentag_2002/1.risiko_riskmgmt handout.pdf 10.02 .2004 


\section{CHAPTER 4}

Pressure ulcer risk assessment in the early postoperative ICU-period after cardiac surgery - does it meet the goal?

Comparison of three risk assessment instruments for pressure ulcer development

Feuchtinger $\mathrm{J}$, Halfens RJG, Dassen $T$ (2005) accepted for publication in Intensive \& Critical Care Nursing 


\section{Key Points}

The ICU population has a high risk of developing pressure ulcers (Jiricka et al. 1995). According to several national expert guidelines for pressure ulcer prevention (DNQP 2002, EPUAP 2004, Panel for the Prediction and Prevention of Pressure Ulcers in Adults 1992), a risk assessment for every situation in which the patient"s condition is changing should be performed using a standardised risk assessment instrument.

The modified Norton scale (Bienstein et al. 1991), the Braden scale (Bergstrom et al. 1987b) and the 4-factor model (Halfens et al. 2000) were used in a convenience sample of 53 patients to assess the risk for pressure ulcer development in the first five days (ICU) after cardiac surgery procedures.

The number of patients 'at risk' were $>60 \%$ by the 4 -factor model, $>70 \%$ by the modified Norton scale and $>80 \%$ by the Braden scale. Sensitivity and specificity in all scales are insufficient. Thirty-two patients developed a pressure ulcer stage 1 and one patient a pressure ulcer stage 2 .

Patients in the cardiac surgery ICU can be identified as 'at risk' during the first five days after surgical procedure without continuously using a standardised risk assessment instrument in every changing condition. Individual risk assessment by a standardised risk assessment instrument is only recommended to enable initiation of concrete preventive measures based on patient-specific risk factors. 


\section{Introduction}

Pressure ulcers remain a problem in patients following cardiac surgery. Stordeur et al. (1998) describe a pressure ulcer rate of $29.5 \%$ in this population, and even up to more than $50 \%$ in the intensive care population (Jiricka et al. 1995, Fife et al. 2001, Cuddigan et al. 2001) is reported. Risk assessment is the first step in pressure ulcer prevention. We can differentiate between "static" and "continuous" risk assessment.

The goal of the "static" risk assessment with an instrument is to quantify the risk of different individuals in different states of illness, e.g., for reasons of risk adjustment and benchmarking. The "continuous" risk assessment stands for a permanent view on the patients risk factors with the goal to conduct preventive measures which meet the particular risk factor. Accordingly, a risk assessment instrument is helpful if it reflects the risk factors of the special patient population.

Patients in the immediately post-operative phase in the cardiac surgery intensive care unit are considered by staff as basically 'at risk'. If the prevention measures are standardised and directed particularly to the patient"s situation, the question of the relevance of "static" individual risk assessment arises: Is it worthwhile, or does it just cause more work? Patients during and after cardiac surgery procedures are at risk for pressure ulcer development due to the long time on the OR table, the special perfusion and temperature situation during surgery and the immobility in the first phase after surgery (Papantonio et al. 1994 „Nixon et al. 1999, Lewicki et al. 1997). Pressure situations can lead to the occurrence of skin defects not only during the immediate phase after surgery but also after 5-7 days (Kosiak 1959). In general cardiac surgery patients are mobile in the preoperative phase and immobile in the early postoperative phase.

According to the German national expert guideline for pressure ulcer prevention (DNQP 2002) used in German-speaking countries, a risk assessment has to be carried out whenever the patient's condition changes by using a standardised risk assessment instrument like the Norton scale, the Braden scale, or the Waterlow scale. These instruments state a patient as 'at risk' at a certain cut-off-point, e.g. patients with less than 16 points are 'at risk' in the Braden scale. Therefore a risk assessment for each patient in the early postoperative situation would be necessary.

This study was conducted to appraise risk assessment using a standardised instrument. Three risk assessment instruments, the Braden scale, the modified Norton scale and the 4-factor model, were evaluated on their ability to distinguish between cardiac surgery ICU-patients 'at risk' and those "not at risk' in the early postoperative period. The study thus aimed to answer the research question "How many patients in the intermediate period after cardiac surgery procedures 
are 'at risk' for pressure ulcer development according to three commonly-used risk assessment instruments and which instrument best fits the situation of the ICU-patients?".

\section{Risk assessment instruments}

The first step in pressure ulcer prevention management is to identify the patients 'at risk'. For this purpose, a variety of risk assessment instruments are available (McGough 1999). Well-known risk assessment instruments, are e.g. the Norton scale (Norton et al. 1975), the Braden scale (Bergstrom et al. 1987b), the Waterlow scale (Waterlow 1985), the Gosnell scale (Gosnell 1973), to name only a few. An 'easy-to-use" but only once-tested instrument, a "4-factor model", has been devised by Halfens et al. (2000). Identifying the 'best' risk assessment instrument for a specific patient population is a challenging task. "The choice of a risk assessment tool is dependent upon the characteristics of individual patient susceptibility and the clinical value of the tool" (Crow \& Clark 1990). The National Pressure Ulcer Advisory Panel (1989) advised that an ideal 'at risk' assessment tool should have good predictive value, high sensitivity and specificity and should be easy to use (Smith et al. 1995). The modified Norton scale and the Braden scale have been tested in the ICU setting (Jiricka et al. 1995, Bergstrom et al. 1987b, Prölß et al. 1996).

The modified Norton scale, the Braden scale and the 4-factor model were chosen for this study to identify cardiac surgery ICU-patients' risk for pressure ulcer development. The first two scales are used very often in German hospitals. Because it is short, it can be assumed that the 4-factor model would be highly accepted in nursing practice and is therefore included in this study. The concepts of the modified Norton scale, the Braden scale and the 4-factor model the points per concept and the recommended cut-off points are shown in table 1. The cutoff points differentiate the patients 'at risk' and 'not at risk'. E.g. the cut-off point $\leq 25$ in the modified Norton scale means that a patient with 25 or less points is 'at risk. 


\begin{tabular}{|c|c|c|}
\hline Modified Norton scale & Braden scale & 4-fractor model \\
\hline 14 pts $/$ cint of $\leq 25$ & $1-4$ pts Jcult-off $\leq 16$ & 1 pl: $/$ cutwoff $>2$ \\
\hline \multicolumn{3}{|l|}{$\begin{array}{l}\text { shlain condition: } \\
\text { cooperation/motivation } \\
\text { physical condition } \\
\text { addilional diseases } \\
\text { mental statie }\end{array}$} \\
\hline incontinence & sensory perception & sensory perception \\
\hline $\begin{array}{l}\text { actiwity } \\
\text { mobilaty }\end{array}$ & $\begin{array}{l}\text { moisture } \\
\text { activity } \\
\text { mobility } \\
\text { nutrition }\end{array}$ & moisture \\
\hline age & friction \& shear (max. 3 ptsi.) & $\begin{array}{l}\text { friction \& shear } \\
\text { age }\end{array}$ \\
\hline
\end{tabular}

Two indices are used to evaluate the accuracy of a test - sensitivity and specificity. Sensitivity measures the ability of the instrument to assess the patients 'at risk" whereas the specificity measures the ability of the instrument to assess the patients 'not at risk. The higher the result, the better the differentiation accuracy of an instrument. Additionally "the positive and negative predictive value provide information about the predictive power of the instrument (Lilienfeld 1994). Results of sensitivity and specificity for the instruments under study are shown in table 2.

For all these measurements, it is essential to determine the "best" cut-off point of an instrument. The cut-off point of pressure ulcer risk assessment instruments with the best predictive power has often been discussed in the literature (Bergstrom et al. 1987b, Edwards 1994, Halfens 2000). It is recommended that the cut-off point be calculated for each specific population.

Table 2 Sensitivity and specificity of risk assessment scales tested in the ICU seiting

\begin{tabular}{|c|c|c|c|c|c|}
\hline & Author & Sample size & Bensitivity & Spedficity & $\begin{array}{l}\text { Developing } \\
\text { Pressure ulcer }\end{array}$ \\
\hline Modifled Norton scale & Próls el al, 1996 & 111 & $100 \%$ & $8 \%$ & $21 \%$ \\
\hline Braden scale & $\begin{array}{l}\text { Bergstrom et al } 1987 \mathrm{~b} \\
\text { Jirickika, } 1995\end{array}$ & $\begin{array}{l}60 \\
85 \\
\end{array}$ & $\begin{array}{l}83 \% \\
75 \%\end{array}$ & $\begin{array}{l}64 \% \\
65 \%\end{array}$ & $\begin{array}{l}40 \% \\
56 \%\end{array}$ \\
\hline 4-tactor model & Haltens et al. 2000 & \multicolumn{4}{|c|}{ Mot tested in the ICUJ population } \\
\hline
\end{tabular}

Specificity of the modified Norton scale was found to be unsatisfactory in a study of 111 ICU-patients by PrölB et al. (1996). Prölß found that all patients had a risk score below 23 points during the first ten days in the ICU. The sensitivity and specificity results of the Braden scale in the study by Jiricka et al. (Jiricka et al. 1995) are given for a cut-off point of 11. Lewicki et al. (1997) used this instrument to look at the risk factors in the cardiac surgery population. She found that a cut- 
off point of 20 is more appropriate in this population than the cut-off point of 16 recommended by Braden. No data are available for the 4 -factor model.

\section{Methods}

\section{Design}

An explorative prospective design was used in this study to assess the risk for pressure ulcer development in the cardiac surgery ICU-population in a four-week period.

\section{Sample}

A convenience sample of 53 consecutive ICU-patients after all cardiac surgery procedures with a length of stay $\geq 24$ hours was chosen. In general, approximately half of the patients leave the intensive care unit less than 24 hours after surgery. These patients are not included in the convenience sample in this study because an individual risk assessment could not be carried out.

\section{Instruments}

The Braden scale, the modified Norton scale and the 4-factor model, were used to assess the risk for pressure ulcer development.

The grading system as recommended by the European Pressure Ulcer Advisory Panel (EPUAP 2004) was used for the classification of the outcome variable "pressure ulcer" (table 3).

Tabie 3 Pressure ulcer grading by EPUAP

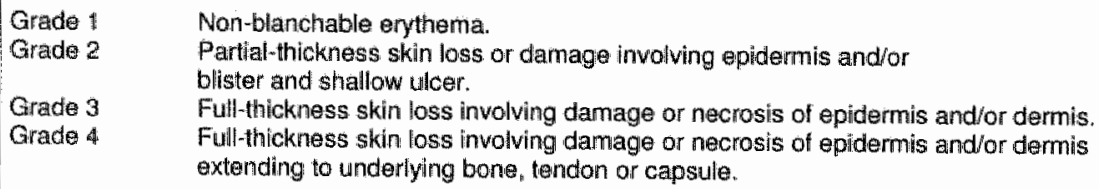

\section{Procedure}

Risk assessments with the modified Norton scale, the Braden scale and the 4factor model and the skin assessments were carried out once a day on the day of surgery and the 4 following days in the morning shift. The observational points were as shown in table 4. 


\begin{tabular}{|c|c|c|c|c|c|c|}
\hline & Beforid Op* & $\begin{array}{c}\text { Affer OP } \\
\text { rop } \\
\text { day }\end{array}$ & Day 1 & Day 2 & Day 3 & Data \\
\hline Rist assessment & 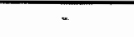 & $x$ & $x$ & $\mathrm{x}$ & $x$ & $\bar{x}$ \\
\hline Sixin inspection & $x$ recordi & $x$ & $x$ & $x$ & $x$ & $x$ \\
\hline
\end{tabular}

"day of surgery

The risk and skin assessments were done by four trained observers who knew about the study. The preoperative skin inspection as a part of the preoperative nursing care check-up was done by the ward nurses immediately before the handover to the operating room nurses. These data were extracted from the patient's record.

\section{Results}

In the four-week period, 53 patients had a length of stay of $\geq 24$ hours in the cardiac surgery ICU, 31 men (58\%) and 22 women (42\%). The age ranged from 25-83 years with a mean of 62 years and a standard deviation of 12 years. The mean length of stay was 3 days. Due to the discharge from the intensive care unit, attrition in the number of patients included in the study was as follows:

$\mathrm{OP}$-day $=53$ pat. $/$ day $\|=53$ pat $/$ day $2=36$ pat. $/$ day $3=20$ pat. $/$ day $4=17$ pat.

\section{Pressure ulcer occurrence}

None of the patients had a pressure ulcer preoperatively. The first postoperative skin assessment was carried out on the admission to the ICU by a nurse and a trained observer. All assessed pressure ulcers were grade 1. One pressure ulcer progressed from grade 1 on the OP-day to grade 2 on the first postoperative day. The occurrence and progress of the pressure ulcers are shown in table 5.

Table 5 Pressure uicer occurrence and progress

\begin{tabular}{|c|c|c|c|c|c|c|c|c|}
\hline $\begin{array}{l}\text { OP-day } \\
N=53\end{array}$ & $\begin{array}{l}\text { 1. } \mathrm{p} . \mathrm{OP} \\
1=53\end{array}$ & $\begin{array}{l}2 \text { p.OP } \\
N=36\end{array}$ & & $\begin{array}{l}\text { 3. P.OP } \\
N=20\end{array}$ & & $\begin{array}{l}\text { 4. } p: Q P \\
N=17\end{array}$ & $\begin{array}{l}\text { Progress to dischargo } \\
\text { (N=53 patiants) }\end{array}$ & $\begin{array}{l}\text { At } \\
\text { discharge }\end{array}$ \\
\hline \multirow[t]{6}{*}{ Now 26} & 12 & & 6 & & 2 & 2 & 2 (grade 2$)$ & 1 (grade \\
\hline & New 2 & & 1 & & 1 & 1 & 0 & 0 \\
\hline & & New & 4 & & 0 & 0 & 0 & 0 \\
\hline & & & & Now & 1 & 1 & 0 & 0 \\
\hline & & & & & & New 0 & 0 & 0 \\
\hline & & & & & & & New 2 grade 1$)$ & 0 \\
\hline
\end{tabular}


What is noticeable is the 26 grade 1 pressure ulcers on the OP-day. We can infer that there is a problem in prevention management in the operating room. The pressure ulcer of one patient remained grade 2 until discharge from the hospital. A second patient's ulcer progressed from grade 1 to grade 2. One patient developed a degenerated pressure ulcer grade 1 again. A fourth patient developed a new pressure ulcer grade 1 on day seven after the surgical procedure. Of all the patients included, one left the hospital with a pressure ulcer grade 2.

\section{The risk}

Most patients after cardiac surgery procedures are discharged $<24 \mathrm{~h}$ from the ICU. The patients who stay longer than 24 hours are more likely to be less mobile, more restricted in their activities, and less likely to resume oral intake. Friction-and-shear forces occur when the patient is sitting in a pilot-seat or with the upper body raised. The sensory perception and mental status in this population are relevant if the patient is on the ventilator. The skin condition and the physical condition usually are unremarkable. Incontinence seldom occurs.

The number of patients stated as "at risk' by the three assessment instruments is shown in figure 1. The cut-off points used are $\leq 20$ points for the Braden scale, $\leq 25$ for the modified Norton scale and $\geq 2$ for the 4 -factor model.

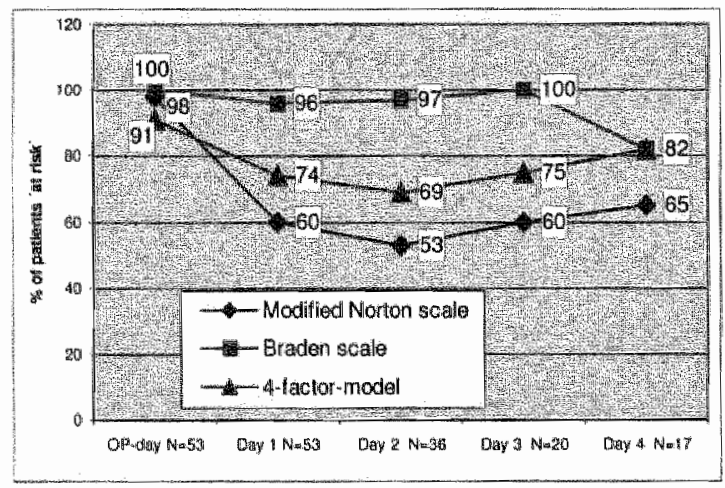

Figure I The rilik

According to the Braden scale, $>90 \%$ of the patients are at risk on each of the first four days. The risk curve decreases on the fourth postoperative day. The 
modified Norton scale and the 4-factor-model show a decrease of patients at risk on the first two days after surgery and an increase on days 3 and 4 after surgery.

Tables 6 to 8 show sensitivity, specificity, positive and negative predictive value of the Braden scale, the modified Norton scale and the 4-factor-model for day 1 postoperative with different cut-off points. Table 9 shows the calculation of the measures of association.

Table 6 Sensitivity, specificity, positive and negative predictive value of the Braden scale with different cut-off points on clay 1 postoperative

\begin{tabular}{|c|c|c|c|c|}
\hline \multirow{2}{*}{$\begin{array}{l}\text { Cut-off } \\
\text { point }\end{array}$} & \multicolumn{4}{|c|}{ Day 1 No53 } \\
\hline & Sensiltivity & Spectiticily & $\begin{array}{l}\text { Positivg } \\
\text { pred. valide }\end{array}$ & $\begin{array}{l}\text { Negative: } \\
\text { pred: vallue }\end{array}$ \\
\hline 20 & $97 \%$ & $5 \%$ & $69 \%$ & $50 \%$ \\
\hline 16 & $78 \%$ & $29 \%$ & $70 \%$ & $38 \%$ \\
\hline 11 & $31 \%$ & $100 \%$ & $100 \%$ & $41 \%$ \\
\hline 10 & $22 \%$ & $100 \%$ & $100 \%$ & $38 \%$ \\
\hline$\overline{9}$ & $20 \%$ & $100 \%$ & $100 \%$ & $37 \%$ \\
\hline
\end{tabular}

Table 7 Sensitivity, specificily, positive and negative predictive value of the modified Norton sciale with different cut off points on clay 1 postoperative

\begin{tabular}{|c|c|c|c|c|}
\hline \multirow{2}{*}{$\begin{array}{l}\text { Cut=off } \\
\text { point }\end{array}$} & \multicolumn{4}{|c|}{ Day $1 \mathrm{Na} 53$} \\
\hline & Sensilivily & Specilicilly & $\begin{array}{l}\text { Postance } \\
\text { predin value }\end{array}$ & $\begin{array}{l}\text { Negallive } \\
\text { prent walue }\end{array}$ \\
\hline 25 & $58 \%$ & $47 \%$ & $70 \%$ & $35 \%$ \\
\hline 23 & $41 \%$ & $88 \%$ & $88 \%$ & $42 \%$ \\
\hline 21 & $33 \%$ & $94 \%$ & $92 \%$ & 400 \\
\hline 19 & $25 \%$ & $100 \%$ & $100 \%$ & $39 \%$ \\
\hline
\end{tabular}

Table 8 Sensilivity, spechicity, positive and negative predictive value of the 4 fiactor model

\begin{tabular}{|c|c|c|c|c|}
\hline \multirow{2}{*}{$\begin{array}{l}\text { Cut-ott } \\
\text { point }\end{array}$} & \multicolumn{4}{|c|}{ Day $1 \mathrm{~N}-53$} \\
\hline & Sensitivily & Specificity & $\begin{array}{l}\text { Posintwe } \\
\text { pred. watue }\end{array}$ & $\begin{array}{l}\text { Nisgative } \\
\text { pres, value }\end{array}$ \\
\hline 22 & $85 \%$ & $31 \%$ & $70 \%$ & $38 \%$ \\
\hline
\end{tabular}

Table 9 Measurement of the association measuras

\begin{tabular}{|c|c|c|c|c|c|}
\hline & $\begin{array}{l}\text { Piessure } \\
\text { Yes }\end{array}$ & $\begin{array}{l}\text { Ullcer } \\
\text { No }\end{array}$ & Fesull & $\begin{array}{l}\text { Sensitivity }(\%): \\
\text { Soecificity }(\%)\end{array}$ & $\begin{array}{l}A:(A+C) \times 100= \\
D: 1 B+D) \times 100=\end{array}$ \\
\hline $\begin{array}{c}\text { Exposed Yes } \\
\text { No }\end{array}$ & (A) & (9) & & Positive predictive value: & $A:(A+B) \times 100=$ \\
\hline Presult & & & & $\begin{array}{l}\text { Nagative predictive value: } \\
\text { Formula by Lilienteld, D. \& }\end{array}$ & $\begin{array}{l}\mathrm{D}:(\mathrm{C}+\mathrm{D}) \times 100= \\
\text { alley, } \mathrm{P} .1994\end{array}$ \\
\hline
\end{tabular}

The results are variable. None of the results satisfactorily differentiate the patients "at risk' and 'not at risk' for pressure ulcer development. The sensitivity, specificity, positive and negative predictive values on the other days (OP-day, 
day 2-4) are similarly distributed. However, we have to keep in mind that inaccuracy could be due to the standardised preventive measures (preventive mattresses, turning intervals) each patient gets on the ICU. If, in the opinion of expert nurses, the patient would definitely have developed an ulcer had preventive measures not been initiated, the instruments would show high sensitivity and specificity results.

\section{Discussion}

"How many patients in the intermediate period after cardiac surgery procedures are 'at risk' for pressure ulcer development according to three commonly-used risk assessment instruments and which instrument best fits the situation of the ICU-patients?" were the research questions for this study.

The Braden scale identifies most patients as 'at risk' in the first five postoperative days in the ICU. We can interpret that its concepts best fits in the situation of cardiac surgery ICU-patients and therefore this scale can be recommended for this population. The modified Norton scale does not include the concepts nutrition and friction and shear, which are relevant in this population. The 4-factor model omits activity, mobility and nutrition. Restricted mobility and activity, friction and shear forces and restricted nutrition intake are common factors during the stay in the ICU. If any of these concepts is not included in an instrument, it is not measured and cannot yield a prediction for pressure ulcer development.

Nevertheless, sensitivity and specificity as the ability of the scale to differentiate correctly between patients at risk and not at risk is unsatisfactory for all scales. The same result is found for the positive and negative predictive values, that is, the ability of the instruments to forecast the probability of pressure ulcer development.

For "static" risk assessment it is recommended that the cut-off point be adjusted for each patient population. Adjusting the cut-off point depends on the result of the sensitivity and specificity calculation. The consequences for nursing management and nursing practice are considerable. First, a decision has to be made about the most efficient risk assessment instrument for the specific patient population, e.g. cardiac surgery, cardiac surgery ICU, cardiology and so on. This lask depends on the specific risk concepts of the population under consideration. In a second step, the cut-off point of the instrument for the specific patient population has to be adjusted. In a third step, the nurses have to be educated in the correct use of the instrument. On units with patients of more than one speciality, the nurses would have to know the "best" risk assessment instrument 
for each patient and additionally which cut-off point is appropriate. This scenario must be seen against the background of a wide variation in sensitivity, specificity, positive and negative predictive values of the risk assessment instruments (McGough 1999). Moreover, a risk assessment should support the clinical judgement of the nurse and not replace it (DNQP 2002, Halfens 2000). In this light, it would not be appropriate to recommend adjusting the cul-off point for each patient population. A particular cut-off point can be helpful for use in practice but should be seen as a guideline.

Nurses have to keep in mind that risk assessment instruments are helpful for a continuous risk check to meet the particular risk factor with suitable preventive measures. The individual "static" risk assessment in the cardiac surgery ICUpopulation studied here does not lead to more effective prevention measures. These measures are standardised. If we know that a high proportion of a patient population is 'at risk' for pressure ulcer development, an individual static risk assessment is useful to confirm this knowledge and for benchmarking reasons but is not necessary in general. In times when resources are increasingly restricted, every nursing task has to be evaluated for its use or advantage to reach a goal. A comment by the nurses of the cardiac surgery ICU on the results of risk assessment using the three risk assessment instruments confirms this statement and leads to further research: "We know that all our patients are 'at risk'. But we have patients who are 'at high and special risk' for pressure ulcer development and how can we assess them?"

\section{Conclusion}

Of the 53 patients studied, 31 developed a pressure ulcer grade 1 and one patient a pressure ulcer grade 2. The peak lies on the OP-day after the surgical procedure. This suggests a problem in the operating room. Risk assessments using the modified Norton scale, the Braden scale and the 4-factor model show high numbers of patients 'at risk' throughout. The highest numbers are given by the Braden scale, which can be traced to the concepts of this scalle. Restraints in activity, mobility, nutrition and the occurrence of friction and shear are significant in the cardiac surgery ICU-population. The results of the sensitivity and specificity calculation show that the discrimination of patients "at risk" and those 'not at risk" by the assessment instruments used is not adequate. The outcome for the positive and negative predictive values is similar. All the results have to be seen under the condition that the prevention measures were not included in the calculation. In a population where the risk for pressure ulcer development is 
generally high, it is not necessary to carry out a "static" risk assessment for each patient. The individual risk assessment is only useful in the sense of a continuous view of the particular risk factors and to conduct specific prevention interventions. 


\section{References}

Bienstein $C$ et al. Risikopatienten erkennen mit der erweiterten Nortonskala. In: DBfK (ed) Dekubitus. Prophylaxe - Therapie. 2. Aufl. Frankfurt/M:Verlag Krankenpflege; 1991:66-74

Bergstrom $N_{1}$ Braden $B J$, Laguza $A$, Holman $V$. The Braden scale for predicting pressure sore risk. Nurs Res. 1987b;36:205-210

Crow $R_{n}$ Clark $M$. Current management for the prevention of pressure sores. In: Bader $D L$ (ed) Pressure Sores: Clinical Practice and Scientific Approach. Basingstoke, London: Mac Millan Press Ltd.; 1990

Cuddigan J, Ayello EA, Sussman C. (eds.). Pressure Ulcers in America: Prevalence Incidence, and Implications for the Future. 2001; Reston, VA: NPUAP

Deutsches Netzwerk für Qualitătsentwicklung in der Pflege (DNQP). Expertenstandard Dekubitusprophylaxe in der Pflege. Entwicklung - Konsertierung - Implementierung. 2002; ISBN: 3-00-009033-9

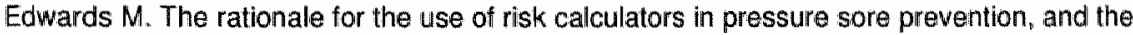
evidence of the reliability and validity of published scales. J Adv Nurs. 1994:20:288-296

European Pressure Ullcer Advisory Panel (EPUAP) http://Www.epuap org/gpreventiont html 2004-07-12

European Pressure Ulcer Advisory Panel (EPUAP) http://www.epuap.org/gltreatment.htm/ 2004-07-12

Fife $C$, Otto $G$, Capsuto $E G$, et al. Incidence of pressure ulcers in a neurologic intensive care unit. Crit Care Med. 2001;2(29):283-90

Gosnell DJ. An assessment tool to identify pressure sores. Nurs Res. 1973;22:55-59

Halfens RJG. Risk assessment scales for pressure ulcers: a theoretical, methodological, and clinical perspective. Ostomy/Wound Man. 2000;46(8):36-44

Halfens RJG, Van Achterberg T, Bal RM. Validity and reliability of the Braden scale and the influence of other risk factors: a multi-centre prospective study. Int J Nurs Stud. 2000:37:313-19

Jiricka MK, Ryan P, Garvalho, MA, Bukwich J. Pressure ulcer risk factors in an ICU population. Am J Crit Care. 1995;4(5):361-367

Kosiak M. Etiology and pathology of ischemic ulcers. Archives of Physicai Medicine \& Rehabilitation. Feb 1959

Lewicki $L J$ et al. Patient risk factors for pressure ulcer during cardiac surgery. AORN $J$. $1997 ; 65(5) \div 933-94$

Lillienfeld DE. Foundations of Epidemiology. $3^{\text {td }}$ ed. Revised by Lilienteld DE \& Stolley PD. Now York: Oxford University Press; 1994

McGough A. A systematic review of the effectiveness of risk assessment scales used in the prevention and management of pressure sores. MSc Thesis, University of York; 1999

National Pressure Ulcer Advisory Panell. Pressure ulcers - incidence, economics and risk assessment. Care-Science and Practice. 1989;7(4):96;99 
Nixon $\mathrm{j}$ et al. A sequential randomised controlled trial comparing a dry visco-elastic polymer pad and standard operating fable mattress in the prevention of post-operative pressure sores. Int $J$ Nurs Studies. 1999;35(4):193-203

Norton D, McLaren R, Exton-Smith AN. An Investigation of Geriatric Nursing Problems in Hospital. Edinburgh: Churchill Livingstone; 1975:194-238

Panel for the Prediction and Prevention of Pressure Llicers in Adults. Pressure Ulcer in Adults: Prediction and Prevention. Clinical Practice Guideline, Number 3. AHCPA Publication No. 920047, Rockville, MD: Agency for Health Care Policy and Research. Public Health Service, US Department of Heath and Human Services, May 1992

Papantonio CT, Wallop KB, Kolodner KB. Sacral ullcers following cardiac surgery: Incidence and risks. Adv Wound Care. 1994;7:24-26

PrölB J, Elbers P, Caspers A. Entwicklung einer Dekubitusrisikoskala für Intensivpatienten. Intensiv. 1996:4:260-71

Smith LN et al. A critique of 'at risk" pressure sore assessment tools. J Clin Nurs. 1995;4:153-159

Stordeur $S_{4}$ Laurent $S \& D$ Hoore $W$. The importance of repeated risk assessment for pressure sores in cardiovascullar surgery. Joumal of Cardiovascular Surgery. 1998;39(3), 343-49

Waterlow 4 . A risk assessment card. Nurs Times. $1985 ; 27: 49,51,55$ 


\section{CHAPTER 5}

A $4 \mathrm{~cm}$ thermoactive viscoelastic foam pad on the operating room table to prevent pressure ulcer during cardiac surgery

Feuchtinger J, Halfens RJG, Dassen T, De Bie R (2005)

accepted for publication in Journal of Clinical Nursing 


\section{Abstract}

Aims and objectives: In this experimental study, a $4 \mathrm{~cm}$ thermoactive viscoelastic foam overlay and a heating source on the operating room table was compared to the standard operating room table with a heating source for the effect on the postoperative pressure ulcer incidence in cardiac surgery patients.

Background: Pressure ulcer incidence in the cardiac surgery population is reported to be up to $29.5 \%$. The prolonged compressive forces from lying on the operating room (OR) table are one source of pressure ulcer development in this population. Pressure-reducing devices on the OR-table should reduce the patients' interface pressure and thus the hazard of skin breakdown.

Methods: A randomised controlled trial was performed to test the effect of a $4 \mathrm{~cm}$ thermoactive viscoelastic foam overlay with a water-filled warming mattress on the OR-table (test OR-table) compared to the standard OR-table (a water-filled warming mattress, no pressure-reducing device) on the postoperative pressure ulcer incidence in cardiac surgery patients.

Instruments: The pressure ulcer classification system of the European Pressure Ulcer Advisory Panel (EPUAP) was used for pressure ulcer grading.

Results: The results show that patients lying on the $4 \mathrm{~cm}$ thermoactive viscoelastic foam overlay suffer slightly more pressure ulcer $(17.6 \%)$ than patients on the standard OR-table without the foam overlay (11.1\%).

Limitations: Due to the clinical relevance of the results, the RCT was terminated after 175 patients at the interim analysis although the power calculation stated 350 patients.

Conclusions: The combination of a $4 \mathrm{~cm}$ viscoelastic foam overlay and a warming source cannot be recommended for pressure ulcer prevention on the operating room table. 


\section{Introduction}

Patients undergoing prolonged surgical procedures, like cardiac surgery interventions, lie a long time in the same position on the OR-table, and are therefor at risk for developing pressure ulcers (Stotts 1999). Although, the intraoperative period is only a part of a surgery patients" pathway and other critical factors occur during the pre- and postoperative period as well, intervention studies show decreased pressure ulcer occurrence if pressure reducing devices on the OR table are used (Hoshowsky \& Schramm 1994, Nixon et al. 1998). A number of systems is available; air-systems, gel pads, foam overlays and combined foam and gel overlays. There is lack of evidence concerning the effects of foam pads in general and more specifically to viscoelastic foam pads.

Clinical trials report on the positive effects of foam overlays in beds (Whittemore 1998, Cullum et al. 1995) however, only Hawkins (1997) compared the standard OR table with a "speciality foam pad" and an air-filled pad but gave no data on the specific effects per intervention.

Viscoelastic foams have unique properties in density, tensile, fatigue and fracture toughness, and are available as thermoactive and thermo-inactive foams. In comparison to other foams the viscoelastic foam characteristics result in a better body adaptation, a larger contact surface and a more effective pressure reduction (IGAP 2005).

Cardiac surgery patients are cooled and reheated during surgical procedures with extracorporal circulation (ECC), which creates extra circulatory demands. In most cardiac surgery operating rooms a warming source is used to quickly reach the patients' preoperative temperature.

At the Department for Cardiovascular Surgery at the University Hospital Freiburg a $4 \mathrm{~cm}$ thermoactive viscoelastic foam pad combined with a warming mattress on the OR table is to be implemented for pressure ulcer prevention. Empirical data on this combination is not available. This study investigates the effect of a $4 \mathrm{~cm}$ thermoactive viscoelastic foam pad on the OR-table in combination with a warming mattress to reduce pressure ulcer incidence in the cardiac surgery population.

\section{Methods}

\section{Design}

A randomised controlled trial was chosen to compare the effect of 
- the standard OR table configuration (OR table with waterfilled warming mattress) versus

- the test OR table configuration (OR table with waterfilled warming mattress and a $4 \mathrm{~cm}$ thermoactive viscoelastic foam overlay) on patients undergoing cardiac surgery with ECC.

\section{Patients}

Patients were recruited from the Department for Cardiovascular Surgery at the University Hospital Freiburg, Germany, if they met the following inclusion criteria: scheduled for cardiac surgery with extracorporal circulation, aged $\geq 18$ years, not included in another study, and written informed consent obtained.

Included patients were randomised to either the standard operating table configuration or the test configuration. Both $O R$ tables where additionally covered with a moisture keeping disposable sheet and a cotton sheet. The warming mattress was started after the surgeons command to warm the patient, ten minutes before opening the aortic cross-clamp, and adjusted to $36.5^{\circ} \mathrm{C}$. The postoperative nurses who assessed the skin condition were unaware of the patient assignment. Patients were also kept unaware about the configuration.

\section{Outcome criteria}

As a primary outcome measure to grade pressure ulcers the pressure ulcer classification system as recommended by the European Pressure Ulcer Advisory Panel (EPUAP 2005) was used:

Grade 1 Non-blanchable erythema.

Grade 2 Partial-thickness skin loss or damage involving epidermis and/or blister and shallow ulcer.

Grade 3 Full-thickness skin loss involving damage or necrosis of epidermis and/or dermis.

Grade 4 Full-thickness skin loss involving damage or necrosis of epidermis and/or dermis extending to underlying muscle, bone, tendon or capsule.

Data on pressure ulcers were assessed preoperatively at the handover of the patient to the operating room nurse, postoperatively at the handover to the intensive care unit (ICU) nurse, day 1 , day 3 and day 5 according to Kosiaks findings (Kosiak 1959) that ulceration occurs with an average time of 4.5 days after a pressure sensation. The length of stay after the surgical procedure limited the observation time to five days.

During a three-months period a set-up training was provided to ward, theatre and intensive care staff involved in the study. The interrater reliability of the skin 
assessment tool was assessed between clinical staff and the research nurses with 90 patients. Patients were first assessed by a staff nurse.

If a skin alteration occurred a second skin assessment was carried out by the research nurse during the following hour. Nurses were all trained in skin assessment and pressure ulcer classification. All data were recorded in daily routine and covered for study documentation by the research nurses. If nurses were uncertain about a skin condition a study nurse was incorporated in the skin inspection and judgement.

Sex, age, body mass index, additional diseases (diabetes mellitus, renal insufficiency, cerebrovascular diseases, lung diseases), preoperative haemoglobin and haematocrit level, type of surgery, temperature course during surgery, bypass time, katecholamine substitution, pressure ulcer risk (modified Norton scale) and time on OR table were documented to assess risk factors associated with pressure ulcer development.

\section{Statistical considerations}

The trial was designed to detect an absolute difference in the incidence of operating room generated pressure ulcers from $30 \%$ on the standard operating table configuration to $15 \%$ on the test operating table configuration with $90 \%$ power at the 5\% significance level (Pocock et al. 2002). Based on the estimated difference of $15 \%$ in pressure ulcer incidence 350 patients were needed. Independent interim analysis was stipulated from the ethical committee after 175 patients.

Data were checked for completeness and normality and stored in a database. Missing values were substituted in concordance with baseline carry forward principle.

Statistical analysis was based on the "intention to treat" principle, using SPSS software package 11.5.1 for Windows (asknet AG, German version). Chi-squarestatistics was used to test the proportional difference in "pressure ulcer" incidence in the two study arms. Analysis of covariates was carried out using a logistic regression model.

\section{Results}

Patients were recruited from January to June 2004. 175 patients were randomised in the trial when the stipulated interim analysis population was reached. 85 patients were randomised to the test table group and 90 patients to the standard table group. The patient characteristics are given in table 1. 


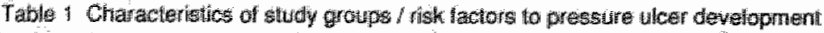

\begin{tabular}{|c|c|c|c|c|c|c|c|c|c|c|}
\hline \multirow[t]{2}{*}{ Wartabia } & \multicolumn{4}{|c|}{ 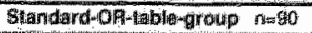 } & \multicolumn{4}{|c|}{ 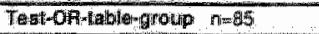 } & \multirow{2}{*}{ 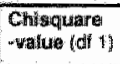 } & \multirow[b]{2}{*}{ P.-valute } \\
\hline & thint. & Ming & Hotern & Sh, day. & Min. & Mas & B/W: & Sil Abryt. & & \\
\hline $8 \pi$ & \multicolumn{4}{|c|}{267.928} & \multicolumn{4}{|c|}{$e^{6}, 27$} & 9.90 & 0.59 \\
\hline Agro (yory & 33 & 92 & 67.6 & 10.8 & 3 & 92 & 68 & 91 & 072 & 0.40 \\
\hline Eody midss inder & 18.6 & 40.5 & 20.6 & 42 & 19. . & 482 & 27.2 & 4 & 0.46 & 0.50 \\
\hline 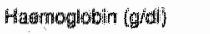 & 0.8 & 90,4 & 14 & $2: 5$ & 3 & 17.7 & $13: 5$ & 11.7 & 0.21 & 0.65 \\
\hline Famedom & 28.6 & 55.4 & 41.7 & 6.7 & 284 & $54: 6$ & 40.5 & 4.8 & 0.06 & 0.80 \\
\hline 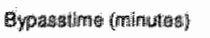 & 14 & 228 & 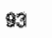 & 34 & 2 & 238 & 9 & 40 & 0.0 .5 & 0.82 \\
\hline Trima. Og-beging & 345 & 37.1 & 35.9 & 0.5 & 35 & 37.2 & 35 & 0.5 & \$.67 & 0.20 \\
\hline Low & 227 & 30 & $3 \sqrt[4]{4} \cdot \sqrt{5}$ & 1.4 & 28 & 35.2 & 347 & 0. & 0.14 & 0.74 \\
\hline 1. Tuma. ICU & 34 & 39.6 & 36 & 0.8 & 23 & 39.1 & 35 & 0.7 & 1.5 .3 & 0.22 \\
\hline OH the (hrs) & 1.5 & 2 & 3.7 & 0.5 & 22 & 7.6 & 3.9 & 1. & 0.044 & 0.84 \\
\hline Thum on oN tabla (fint) & 3.4 & : 6 & 5.6 & 1.0 & 3.8 & 9.4 & 58 & 13 & 0.53 & 0.47 \\
\hline Nilortor - Pointh presp. & 13 & 26 & $2 \leq 2$ & 24 & 17 & 25 & 22.6 & 18 & 0.6 & 0.43 \\
\hline 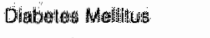 & \multicolumn{2}{|c|}{$33 \%$ yo: } & \multicolumn{2}{|c|}{$57 \%$} & \multicolumn{2}{|c|}{$29 \sin _{0}$} & \multicolumn{2}{|c|}{$7 \% \%$ no } & 0.20 & 0.59 \\
\hline Funal wated & \multicolumn{2}{|c|}{$27 \%$ y然 } & \multicolumn{2}{|c|}{$73 \%$} & \multicolumn{2}{|c|}{$284 \%$} & \multicolumn{2}{|c|}{$72 \%$ no } & 4.02 & 0.05 \\
\hline Lung Gistares & \multicolumn{2}{|c|}{$28 \%$ yeas } & \multicolumn{2}{|c|}{$72 \%$ no } & \multicolumn{2}{|c|}{$25 \%$ yes } & \multicolumn{2}{|c|}{$75 \%$ no } & 2.88 & 0.30 \\
\hline 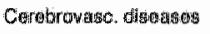 & \multicolumn{2}{|c|}{706 yos. } & \multicolumn{2}{|c|}{$92 \%$ no } & \multicolumn{2}{|c|}{ 11\% yes } & \multicolumn{2}{|c|}{ gaso no } & 0.01 & 0.919 \\
\hline Orinype & \multicolumn{4}{|c|}{ 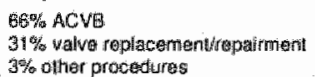 } & \multicolumn{4}{|c|}{ 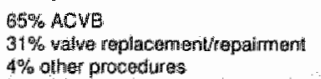 } & $3.27(013)$ & 0.315 \\
\hline
\end{tabular}

A total of 90 paired assessments were undertaken for the interrater reliability assessment. There was disagreement for 23 of the observed $990(2.3 \%)$ skin sites (shoulders, elbows, buttocks, sacrum, heels), affecting 11 (12.2\%) patients. Disagreement were between blanchable erythema and grade 1 pressure ulcer and in one situation between grade 1 and a questionable grade 4 pressure ulcer. One heel showed a violet discoloration and it was unclear what kind of pressure ulcer should be stated. The discoloration disappeared on day 3 postoperatively and did not reappear until discharge on day 7 . This skin change was retrospectively declared a grade 1 pressure ulcer.

\section{Primary endpoint}

The main endpoint in the interim analysis was determined for 175 patients. The overall postoperative pressure ulcer incidence was $14.3 \%$ for both patient groups, $11.1 \%$ for the standard table group and $17.6 \%$ for the test table group. The Chisquare test statistics showed a p-value of $0.22\left(\mathrm{X}^{2}\right.$-value $\left.1.53, \mathrm{df} 1\right)$ to develop a pressure ulcer on the test OR table. A probability analysis showed a $9.7 \%$ likelihood to reach the stated difference of $15 \%$ less pressure ulcers in the test group by 350 patients.

Based on these results the study executives and the data monitoring committee decided to halt the RCT. 


\section{Grades and sites}

Four patients had a pressure ulcer grade 1 at the handover from the ward to the OR which is a preoperative incidence of $2.3 \%$. Three patients had the pressure ulcer on the heels, one patient on both elbows. These pressure ulcers were resolved at the first assessment after the operation. The postoperative pressure ulcer occurrence and grades are shown in table 2.

Table 2 Pressure ulcer oceurence and grades

\begin{tabular}{|c|c|c|c|c|c|c|c|c|}
\hline \multirow[t]{2}{*}{ Table 1} & \multicolumn{4}{|c|}{ Standerd table $n=90$} & \multicolumn{4}{|c|}{ Test table $n=85$} \\
\hline & $y$ & 2 & 3 & 4 & I: & 2 & 3 & t \\
\hline Pop day 0 & 7 & - & - & - & 100 & 1 & - & 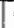 \\
\hline Pop daly & 9 & - & - & - & 2 & 1 & - & . \\
\hline Pop daly 3 & 1 & औ & - & - & 1 & " & - & se \\
\hline Pop daly 5 & . & - & -. & . & - & - & - & . \\
\hline Total & 9 & 1 & & & 13 & 2 & & \\
\hline
\end{tabular}

The majority of the observed pressure ulcers were skin changes from grade 0 preoperatively to grade 1 postoperatively $(7 / 10)$. One patient in the standard table group and two patients in the test table group developed a pressure ulcer grade 2 $(1,7 \%)$. One patient during the operation and two patients on postoperative day 1 and 3. Skin changes were observed on sacrall (10), buttocks (16), heels (5), elbows (1) and shoulders (2). Of the 17 pressure ulcers grade 1 immediately after the surgical procedures 14 resolved until the postoperative day 1 . The remaining 3 pressure ulcers grade 1 resolved until postoperative day 3 . One of the pressure ulcers grade 2 occurred as a bladder on postoperative day 0 (after the surgery procedure) and persisted for another 5 days. One patient developed a pressure ulcer grade 2 on postoperative day 1 which resolved on day 8 after the surgical procedure. A pressure ulcer grade 2 detected on day 3 was healed on day 5 . If a patient had a pressure ulcer on day 5 postoperatively, he/she was observed till discharge or until the pressure ulcer resolved. Two patients with a pressure ulcer grade 1 on day 5 postoperatively had skin integrity at day 7 postoperatively. The progress of the pressure ulcers is shown in table 3. None of the patients were discharged with a pressure ulcer. 


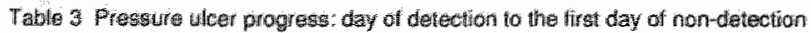

\begin{tabular}{|c|c|c|c|}
\hline Prop day 0 & Pop day 1 & Pop diay 3 & Further days \\
\hline \multicolumn{4}{|c|}{ 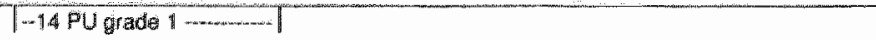 } \\
\hline \multicolumn{4}{|c|}{$\|-3$ PU grade 1 - } \\
\hline \multicolumn{4}{|c|}{1 - 1 PU girde 2 - } \\
\hline \multicolumn{4}{|c|}{ | 2 PU grado 1 -...... } \\
\hline \multicolumn{4}{|c|}{$\mid-1$ PU grade 1 . } \\
\hline \multicolumn{4}{|c|}{ | w 1 PU grade 2 -......... day 8} \\
\hline \multicolumn{4}{|c|}{$\mid-1$ pu grade $1 . . . . . . . \mid$} \\
\hline \multicolumn{4}{|c|}{ 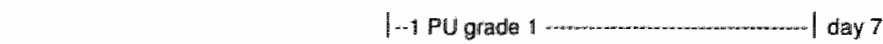 } \\
\hline \multicolumn{4}{|c|}{$\mid .+1$ pu grade $2 \ldots \mid$} \\
\hline
\end{tabular}

Pop day = postoperative day

\section{Secondary endpoint}

As secondary endpoint the risk factors associated with pressure ulcer development were explored. The effect of the variables thought to be important in the cardiac surgery population according to the literature (Kemp et al. 1990, Papantonio et al. 1994, Jerusum et al. 1996, Lewicki et al. 1997, Stordeur et al. 1998, Pocorny 2003) including age, body mass index, additional diseases (diabetes mellitus, renal insufficiency, cerebrovascular diseases, lung diseases), preoperative haemoglobin and haematocrit level, type of surgery, temperature course during surgery, bypass time, katecholamine substitution, and time on ORtable, were examined using logistic regression (backward elimination) to see if they modified the estimate of the difference in the incidence of pressure sores between the two OR-table types. The only significantly contributing variable was an additional renal insufficiency $(p=0.05)$. Thus, a patient with this additional disease was more likely to develop a pressure ulcer in this study. The patient characteristics of the standard-OR-table group and the test-OR-table group are shown in table 1.

\section{Discussion}

The independent interim analysis that was stipulated from the ethical committee after 175 patients shows that pressure ulcer occurs in $11.1 \%$ for the standard table group and $17.6 \%$ in the test table group. For this trial an absolute difference in the incidence of operating room generated pressure ulcers from $30 \%$ on the standard operating table configuration to $15 \%$ on the test operating table configuration with $90 \%$ power at the $5 \%$ significance level was calculated. Based on an estimated difference of $15 \%$ in pressure ulcer incidence 350 patients are 
calculated for trial inclusion. The supposed pressure ulcer incidence of $30 \%$ in the standard OR table group was a result of a data collection period in the Department in January 2003. During trial planning quality improvement measures increased and the reduced incidence of $11.1 \%$ in the standard table group may be a result of these measures.

Due to this unexpected result the study executives and the data monitoring committee decided to stop the study at this point. Although the difference is not statistically significant it is of clinical relevance. The patients suffer of slightly more pressure ulcers on the $4 \mathrm{~cm}$ thermoactive viscoelastic foam pad than on the standard table configuration.

The overall pressure ulcer incidence in the here presented study are comparable with findings from other studies in equivalent populations (Stordeur et al. 1998, Kemp et al. 1990, Papantonio et al. 1994, Jerusum et al. 1996, Lewicki et al. 1997 ) which vary between $4.7 \%$ in the study of Lewicki et al. (1997) and $29.5 \%$ in the study of Stordeur et al. (1998). In the study of Stordeur only pressure ulcers grade 2 and 3 were documented.

The $4 \mathrm{~cm}$ viscoelastic foam overlay has not been tested in a clinical trial. Hoshowsky \& Schramm (1994), Papantonio et al. (1994) and Nixon et al. (1998) tested a viscoelastic polymer pad as a gel pad. Hawkins (1997) tested a foam pad and an air-filled pad against the standard operating table for patients who underwent cardiothoracic or major vascular surgery procedures. But she didn't report about characteristics of the foam pad. Krouskop et al. (1986) found a strong correlation for hardness, density, and thickness of the foam overlay and its ultimate potential as a pressure-reducing device. The denser, thicker $(10 \mathrm{~cm})$, flat foam overlays yielded the most effective reduction in tissue interface pressures when compared with other designs $(5 \mathrm{~cm})$. These results are concluded from pressure reducing pads in beds. Defloor \& De Schuijmer (2000) tested five mattresses for the operating table: the standard operating-table mattress, a foam mattress, a gel mattress, a viscoelastic polyether mattress, and a visco-elastic polyurethane mattress. Interface pressure measurements were performed on 36 healthy volunteers. The foam mattress and the gel mattress seem to have little or no pressure-reducing effect; the polyurethane mattress and the polyether mattress reduce interface pressure significantly better $(p<0.001)$; but none of the mattresses reduces pressure sufficiently to prevent the occurrence of pressure ulcers.

The reasons for the pressure ulcer incidence of $17.6 \%$ in the test table group (and only $11.1 \%$ in the standard table group) may be in the combination of the foam pad with a warming source and/or in the height of the overlay. The 
viscoelastic foam pad studied here is sensible to the body temperature of the patient. In combination with the body temperature the foam contours the body and reduces tissue interface pressure. The reaction of the viscoelastic foam pad in combination with an additional warming source is not described. This overlay is also used as a pressure reducing overlay in hospital beds. It is unclear how it works in situations were additionally warmth like fever occurs.

A limitation to the validity of the pressure ulcer occurrence data can result from the skin assessment by nurses in daily routine. It is reported that pressure ulcer data collected by research assistants are more valid than data collected by nurses in daily practice. In a total of 90 paired assessments in the preparation phase of the here presented studies there was disagreement for 23 of observed $990(2.3 \%)$ skin sites. It can be concluded that the pressure ulcer grading carried out by nurses are sufficient. Nevertheless, the possibility of false negative results has to be kept in mind.

\section{Conclusion}

Patients positioned on a $4 \mathrm{~cm}$ thermoactive viscoelastic foam pad on an OR table with a waterfilled warming mattress suffer slightly more pressure ulcers $(17.6 \%)$ than patients positioned on an OR table with the warming source but no pressure reducing device $(11.1 \%)$ in a randomised controlled trial with 175 patients undergoing cardiac surgery procedures with ECC. A $4 \mathrm{~cm}$ thermoactive viscoelastic foam overlay on an OR table with a warming source is not more effective to prevent patients to pressure ulcer as a OR table with a waterfilled warming mattress. Recommended is a higher, e.g. seven centimetre, foam overlay for pressure ulcer prevention on the OR table (Krouskop et al. 1986). Unclear is the reaction of the thermoactive foam with an additional warming source with a max. temperature of $36.5^{\circ} \mathrm{C}$. 


\section{References}

Cullum N, Deeks J, Fletcher A, Long Av Mouneimne H. Sheldon T et al. (1995) The prevention and treatment of pressure sares: How effective are pressure-relieving interventions and risk assessment for the prevention and treatment of pressure sores? Effective Health Care $2(1), 11-16$

Defloor T\& De Schuijmer JDS (2000) Preventing pressure ulcers: an evaluation of four operatingtable mattresses. Applied Nursing Research 13(3), 134-41

EPUAP European Pressure Ulcer Advisory Panel. Pressure Ulicer Treatment Guidelines. Available at: hthp://www.epuap.orgl. Accessed February 04, 2005

Hawkins JE (1997) The effectiveness of pressure-reducing table pads as an intervention to reduce risk of intraoperatively acquired pressure sores. Military Medicine 162(11), 759-61

Hoshowsky VM \& Schramm CA (1994) Intraoperative Pressure Sore Prevention: An Analysis of Bedding Materials. Research in Nursing Health 17, 333-39

IGAP Institut für Innovationen im Gesundheitswesen und angewandte Pflegeforschung. Schaumstofflexikon. Stader Straße 4, 27432 Bremervörde, Germany. Available at: hittp://www igap de/informat/b schaum.htm. Accessed February 05, 2005

Jerusum J, Joseph K, Davis JM \& Suki R (1996) Balloons, beds and breakdown. Critical Care Nursing Clinics of North America 8, 423-40.

Kemp MG, Keithley JK, Smith DW, Morreale B (1990) Factors that contribute to pressure sores in surgical patients. Research in Nursing Health 13, 293-301.

Kosiak M (1959) Ethiology and pathology of ischemic ulcers. Archives of Physical Medicine \& Rehabilitation Feb, $62-69$

Krouskop TA, Noble PS, Brown J \& Marburger R (1986) Factors affecting the pressure distributing properties of foam mattress overlays. Journal of Rehabilitation Research Development 23, 33-39

Lewicki LJ, Mion L, Splane KG, Samstag D, Secic M (1997) Patient risk factors for pressure ulcer during cardiac surgery. AORN Journal 65(5), 933-42.

Nixon J, McElvenny, D, Mason S, Brown J \& Bond S (1998) A sequential randomised controlled trial comparing a dry visco-elastic polymer pad and standard operating table mattress in the prevention of post-operative pressure sores. International Journal of Nursing Studies 35,193 203.

Papantonio CT, Wallop KB \& Kolodner KB (1994) Sacral ulcers following cardiac surgery: lncidence and risks. Advanced Wound Care 7, 24-26.

Pocock SJ, Clayton TC \& Altman DG (2002) Department of medical statistics. Survivall plots of time-to-event outcomes in clinicall trials: good practice and pitfalls. Lancet 359(9318), 1686-89.

Pokorny ME, Koldjeski D, Swanson M. Skin Care Intervention For Patients Having Cardiac Surgery. Am J Crit Care 2003;12:535-544

Stordeur S, Laurent S \& D Hoore W (1998) The importance of repeated risk assessment for pressure sores in cardiovascular surgery. Journal of Cardiovascular Surgery 39(3), 343-49.

Stotts NA (1999) Risk of pressure ulcer development in surgical patients: a review of the literature. Adwanced Wound Care 12(3), 127-36

Whittemore $\mathrm{A}$ (1998) Pressure-reduction support surfaces: a review of the literature. Journal of WOCN $25,6-25$ 


\section{CHAPTER 6}

Temperature regulation and pressure ulcer prevention during cardiac surgery

Feuchtinger J, Halfens RJG, Dassen T, De Bie R (2005)

submitted for publication 


\section{Abstract}

Background: Patients' body temperature regulation and pressure ulcer prevention are needs which have to be met during cardiac surgery procedures. Under- and over-the-patient heat sources and different types of pressurereducing overlays are available. A gold standard relating to the system combination which best fits the situation of cardiac surgery patients is not available.

Aims: To show the effect of a test operating room table configuration (waterfilled warming mattress and an additional $4 \mathrm{~cm}$ thermoactive viscoelastic foam overlay) compared with a standard operating room table configuration (waterfilled warming mattress) on the patients' body temperature and postoperative pressure ulcer occurrence.

Method: Data from a cohort and an experimental study were available. 390 patients were included in the study. 183 patients were positioned directly on a heat source (standard operating table) and 207 patients on a $4 \mathrm{~cm}$ thermoactive viscoelastic foam overlay over a heat source (test operating table). Main outcomes were the perioperative body temperature course and the postoperative pressure ulcer incidence.

Results: $12 \%$ of patients suffered pressure ulcers in the standard-table-group and $17.4 \%$ in the test-table-group. The overall pressure ulcer incidence was $14.9 \%$ for both patient groups. The Chi-square test $(p=0.27)$ shows no difference in pressure ulcer development between standard and test operating room table. The t-test for equality of means shows no significant differences in the temperature means for the patient groups.

Conclusion: $\mathrm{A} 4 \mathrm{~cm}$ thermoactive viscoelastic foam overlay on an operating room table with a warming source is not effective in preventing patients against pressure ulcer and does not influence the patients' temperature course. Unclear is the behaviour of the thermoactive foam with an additional warming source with a max. temperature of $36.5^{\circ} \mathrm{C}$. 


\section{Introduction}

Both temperature regulation and pressure ulcer prevention are essential during cardiac surgical procedures. During cardiac surgery, body temperature is lowered because of induced hypothermia through the cardiopulmonary bypass and heat loss through the operating field(s). At the end of the surgical procedure a patient has to reach normothermia $\left(\geq 36^{\circ} \mathrm{C}\right)$, since ongoing hypothermia is regarded as an adverse event. Postoperative shivering is very uncomfortable for the patient, moreover oxygen need of the body tissues increases (Frank et al. 1993, Bay et al. 1994), peripheral vasoconstriction and blood pressure increases (Frank et al. 1995) and peripheral oxygen saturation decreases (Jones \& McLarren 1965). Hypothermia also influences pressure ulcer development (Scott 1999, Scott et al. 2001). Thermoregulative vasoconstriction occurs at a body core temperature of $\leq 34.5^{\circ} \mathrm{C}$ (Kurz et al. 1995).

A combination of optimal perioperative warming and pressure ulcer prevention in cardiac surgery is not always possible. For the purpose of perioperative warming "under the patient" and "over the patient" warming systems are available. Since in coronary bypass surgery the legs act as a second operating field for harvesting veins, this reduces body surface for a sufficient "over the patient" warming system.

"Under the patient" warming systems consist of water mattresses, air mattresses, gel pads and warming blankets. However, lying directly on a warming source holds the risk of getting thermal injuries and, if the heat source is not pressure reducing, also pressure ulcer development. Some systems (gel systems, forced air systems) promise a combination of warming and pressure ulcer prevention but include other constraints. Gel systems were found to reduce interface pressure only to a small degree (Hoyman \& Gruber 1992, Aronovich et al. 1999, Defloor \& De Schuijmer 2000). Forced air systems, as static-air overlays, have demonstrated favourable findings in pressure reduction capabilities (Whittemore 1998) but can give the surgeon the impression that the patient is moving.

Since each organisation has to decide between the advantages and disadvantages of a system, but hard data are lacking, it was decided to study the effect of a standard operating room (OR) table configuration (water filled warming mattress) and an experimental OR table configuration (water filled warming mattress and an additional $4 \mathrm{~cm}$ thermoactive viscoelastic foam overlay) on the patients' body temperature and postoperative pressure ulcer occurrence.

\section{Methods}




\section{Design}

Data from a cohort and an experimental study were available in which one group of patients was positioned directly on a warming source (standard operating table) and one group of patients on a $4 \mathrm{~cm}$ thermoactive viscoelastic foam overlay over a warming source (test operating table). Main outcome was the perioperative course of the body temperature and postoperative pressure ulcer development.

Following inclusion in the study the cohort patients were positioned onto the standard operating table group from November 2003 to February 2004 or the test operating table group from March 2004 to June 2004. The patients in the experimental study were randomised to either the standard operating table configuration or the test configuration from January to June 2004. The standard operating table consists of the operating table, a warming mattress, a moisture keeping disposable sheet and a cotton sheet. The test operating table has an additional $4 \mathrm{~cm}$ thermoactive viscoelastic foam overlay over the warming source.

\section{Sample}

Patients were recruited from the Department of Cardiovascular Surgery at the University Hospital Freiburg, Germany, if they met the following criteria: scheduled for cardiac surgery with extracorporal circulation, older than 18 years, not participating in another study "and informed consent for the trial patients.

\section{Outcome criteria}

To assess the perioperative body temperature the following measurements were taken:

- preoperative temperature: ear temperature in the morning of the operation day; device: First Temp GENIUS® 3000 A; Sherwood-Davis \& Geck;

- temperature at the beginning of the surgical procedure as bladder temperature; device for this and the following measurements: SIEMENSmonitoring; Typ SC $9000 \mathrm{XL}$; Software VF 1.4; temperature sensor YSI Incorporated, Yellow Springs;

- deepest temperature during the surgical procedure as bladder temperature;

- temperature at the end of the surgical procedures as bladder temperature;

- first temperature at the intensive care unit as bladder temperature.

The operating theatre room temperature is $19^{\circ}$ Celsius for all cardiac surgery procedures in adult patients. The warming mattress was started after the surgeons' command to warm the patient (ten minutes before opening the aortic 
cross-clamp) and adjusted to $36.5^{\circ} \mathrm{C}$. Body core temperature is defined as normothermia $\left(\geq 36^{\circ} \mathrm{C}\right)$, mild hypothermia $\left(32^{\circ}-35.9^{9} \mathrm{C}\right)$, moderate hypothermia $\left(28^{\circ} \mathrm{C}-31.9^{\circ} \mathrm{C}\right)$ and deep hypothermia $\left(<28^{\circ} \mathrm{C}\right)($ Horn 2002).

For pressure ulcer grading the pressure ulcer classification system as recommended by the European Pressure Ulcer Advisory Panel (EPUAP 2005) was used (see table 1).

Table 1 Pressure ulcer classification system by EPUAP (2005)

Grade Non-blanchable erythema.

Grade 2 Partial-thickness skin loss or damage inwolving epidemis and/or blister and shallow ulcer.

Grade 3 Full-thickmess skin loss inwolving damage or necrosis of epidermis andfor dermis.

Grade 4 Full-thickness skin loss inwolving damage or necrosis of epidermis andlor dermis extending to underlying muscle, bone, tendon or capsule.

Pressure ulcer occurrence was assessed preoperatively at the handover of the patient to the OR nurse, postoperatively at the handover to ICU nurse, day 1 , day 3 and day 5 (Kosiak 1959). All data were recorded in daily routine and covered for study documentation by the research nurses. Study nurses gave support if nurses in daily practice are uncertain in the judgement of a skin site. Sex, age, body mass index, diabetes mellitus, renal insufficiency, cerebrovascular diseases, lung diseases, preoperative haemoglobin and haematocrit level, type of surgery, bypass time, katecholamine substitution, OR time and time on OR table were documented to assess risk factors associated with pressure ulcer development.

\section{Analysis}

After obtaining the data, they were checked for completeness and normality and stored in a database. All statistical analyses were carried out using SPSS software package 11.5.1 for Windows (asknet AG, German version). Chi-squarestatistics was used to test the proportional difference of the dependent variable "pressure ulcer" in the two study arms. Temperature differences between the standard and test group for the defined measurement points (last temperature at the preoperative ward, first/deepest/last temperature in OR, first temperature at the $I \mathrm{CU}$ ) were analysed using the independent samples t-test for the significance of the difference between two sample means. Logistic regression was used to assess the influence of the patient characteristics on pressure ulcer development. 


\section{Results}

390 patients were recruited from November 2003 till June 2004.183 patients were included to the standard-OR-table group from November 2003 to February 2004 and 207 patients to the test-OR-table group from March to June 2004. Table 2 reports assessed characteristics and variables of the population under study.

Table 2 Characteristics of study groups / risk factors to pressure ulcer development

\begin{tabular}{|c|c|c|c|c|c|c|c|c|c|c|}
\hline \multirow[b]{2}{*}{ Voitabilo } & \multicolumn{4}{|c|}{ 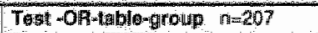 } & \multicolumn{4}{|c|}{ Standard afl-table group $n=183$} & \multirow{2}{*}{$\begin{array}{l}\text { Chisquare: } \\
\text {-value tof if }\end{array}$} & \multirow[b]{2}{*}{ P. value } \\
\hline & Min. & Max. & Nerar & SL, diev: & Min. & Max. & Mearn & St. Dev & & \\
\hline Soix & \multicolumn{4}{|c|}{$m 134_{1 n} \quad 49$} & \multicolumn{4}{|c|}{$m 140,67$} & 1.21 & 0.27 \\
\hline Aga (years & Mo & Q2: & 67.1 & 11:2 & 33 & 93 & 67 & 12 & 2.13 & 0.14 \\
\hline Body mass index & 19.1 & 48.2 & 27.1 & 4.4 & 18: & 40.1 & 26.4 & 3.8 & 0.47 & 0.49 \\
\hline Hemoglebin (g/di) & 6.0 & 17.7 & 131 & 1.9 & 80 & 30.4 & 139 & 2.3 & 0.00 & 0.99 \\
\hline Manatoerfit $(\%)$ & 12.9 & 54.6 & $30.6 \mathrm{i}$ & 5.6 & 24.6 & 55.4 & 44.4 & 5.1 & $0.6 \%$ & 0.80 \\
\hline Eypazstime (Nind) & 28 & 230 & 94 & 31 & 11.4 & 228 & 93 & 29 & 0.00 & 0.99 \\
\hline Temp. OR-begin & 34.8 & 38.1 & 36 & 0.6 & 34.3 & 39 & 30 & 0.6 & 5.32 & 0.21 \\
\hline Lowast OPl-temp. & 29 & 36.3 & 34.7 & 0.9 & 22.7 & 36.4 & 34.5 & 1.4 & 0.32 & 0.86 \\
\hline 1. Tamp. ICU & 33.9 & $3 a_{1}$ & 36 & 0.7 & 34 & 38.8 & 35.9 & 0.7 & 0.57 & 0.45 \\
\hline Oค่ Uก (hrs) & 1,6 & 7.6 & 39 & 1.2 & 11.5 & 0.6 & 3.7 & A. 甫 & 0.75 & 0.39 \\
\hline Time an OR labie (firs) & 3.1 & 0.5 & 5.7 & 1.3 & 3.1 & 10.7 & 5.5 & 1.3 & 1.71 & 0.19 \\
\hline Kaltecholamine In OA & \multicolumn{2}{|c|}{$40 \%$ yes } & \multicolumn{2}{|c|}{$45 \%$ no } & \multicolumn{2}{|c|}{$40 \%$ yos } & \multicolumn{2}{|c|}{$60 \%$ no } & 0.65 & 0.42 \\
\hline Dlabetes Mellitus & \multicolumn{2}{|c|}{$30 \%$ yos } & \multicolumn{2}{|c|}{$70 \%$ no } & \multicolumn{2}{|c|}{$30 \%$ yes } & \multicolumn{2}{|c|}{$69 \%$ no } & 0.95 & 0.33 \\
\hline Henal diserases & \multicolumn{2}{|c|}{$24 \%$ yes } & \multicolumn{2}{|c|}{$78 \%$ no } & \multicolumn{2}{|c|}{$25 \%$ yes } & \multicolumn{2}{|c|}{$75 \%$ no } & 8.19 & 0.04 \\
\hline Lung diseasos & \multicolumn{2}{|c|}{$21 \%$ yes } & \multicolumn{2}{|c|}{$79 \%$ no } & \multicolumn{2}{|c|}{$21 \%$ yes } & \multicolumn{2}{|c|}{$79 \%$ no } & 2.08 & 0.15 \\
\hline Cerebrowasc, disoases & \multicolumn{4}{|c|}{$10 \%$ yos $\quad 90 \%$ no } & \multicolumn{2}{|c|}{ Hox yes } & \multicolumn{2}{|c|}{$90 \%$ no } & 1.51 & 0.22 \\
\hline OA-typa & \multicolumn{4}{|c|}{$\begin{array}{l}63 \% \text { ACVB } \\
30 \% \text { valve repilacinnentirepairment } \\
7 \% \text { other procedures }\end{array}$} & \multicolumn{4}{|c|}{$\begin{array}{l}\text { 67\% ACVB } \\
24 \% \text { valwe repiacementhepaiment } \\
9 \% \text { other prociedures }\end{array}$} & 3.03 yd $3 y$ & 0.43 \\
\hline
\end{tabular}

\section{Study endpoint: pressure ulcer}

$12 \%$ of patients suffer from pressure ulcers in the standard-table-group and $17.4 \%$ in the test-table-group. The overall pressure ulcer incidence was $14.9 \%$ for both patient groups. The Chi-square test $(p=0.27)$ shows no difference in pressure ulcer development between $\mathrm{OR}$ tables. The postoperative pressure ulcer occurrence is shown in table 3 .

Table 3 Pressure ulcer occurrence in the standard table and the test table group

\begin{tabular}{|c|c|c|c|c|c|c|c|c|}
\hline \multirow[b]{2}{*}{ Grade } & \multicolumn{4}{|c|}{ Standard trablo $n=183$} & \multicolumn{4}{|c|}{ Test tabile $n=207$} \\
\hline & 1 & 2 & 3 & 4 & 1 & 2 & 3 & 4 \\
\hline Pop day 0 & 11 & 2 & $=$ & . & 18 & 2 & . & . \\
\hline Pop day 1 & 3 & 4 & - & - & 4 & 1 & . & n \\
\hline Pop day 3 & 3 & 1 & . & - & 6 & - & - & - \\
\hline Pop day 5 & 1 & . & . & . & 3 & 2 & - & . \\
\hline & 18 & 4 & 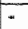 & $\because$ & 31 & 5 & - & - \\
\hline
\end{tabular}


The majority of the observed pressure ulcers were skin changes from grade 0 preoperatively to grade 1 postoperatively. Four patients in the standard table group and five patients in the test table group developed a pressure ulcer grade 2 $(2,3 \%)$. None of the patients developed a pressure ulcer grade 3 or grade 4 . If a patient had a pressure ulcer on day 5 postoperatively, he/she was observed till discharge or until the pressure ulcer resolved. The progress of the pressure ulcers is shown in table 4 . One patient was discharged with a pressure ulcer grade 2 on day eight.

Table * Pressure ulcer progress: day of detection to the first day of non-detection

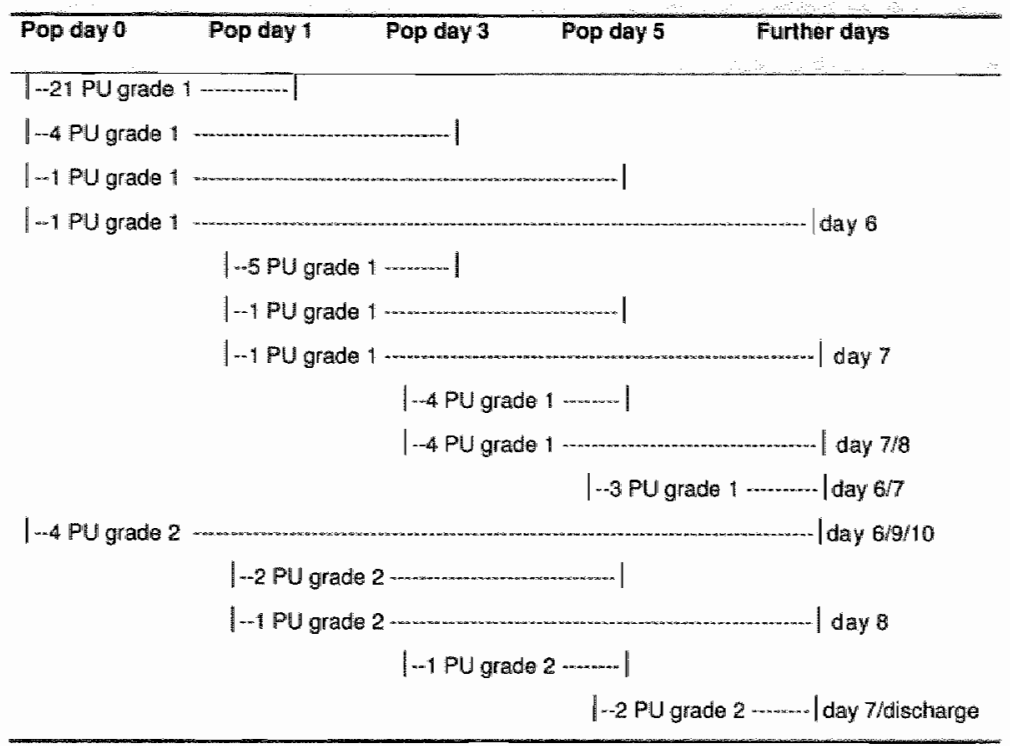




\section{Study endpoint temperature}

The patients' mean temperature courses (in degrees centigrade) are shown in figure 1. Whereas the temperatures measured in $\mathrm{OA}$ and ICU are bladder temperatures the last preoperatively temperature measured on the ward is an ear temperature.

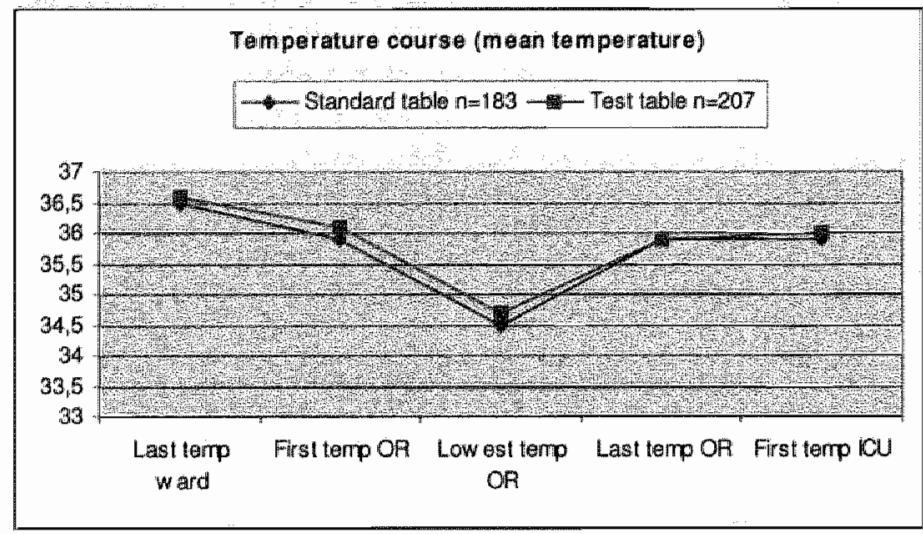

Figure 1 Patients tenperature course on standard OR-table and test OR-table

The t-test for equality of means (table 5) shows no significant differences in the temperature means for the standard and the test table group, although on the whole body temperature on the test table remains a bit higher during the operation.

Talble 5 Termperaturite course

\begin{tabular}{|c|c|c|c|c|c|c|}
\hline \multirow{2}{*}{$\begin{array}{l}\text { Slandard table group me } 183 \\
\text { Test lable group ne } 207\end{array}$} & & \multicolumn{2}{|c|}{ St dev. } & \multicolumn{2}{|c|}{$\begin{array}{l}\text { T-test for equallty of means } \\
\text { Equat waykances assumbod }\end{array}$} \\
\hline & Shand & Tes! & Stand & Tost & $T$ & Stgrt. \\
\hline Lát temp before OR (arar) & 38.5 & 36.6 & 0.49 & 0.44 & $-\pi, 94$ & 0.05 \\
\hline First temp OP (blacter) & 35.9 & 36.0 & 0.63 & 0.56 & -2.12 & 0.03 \\
\hline Lowest lemp OR (bladder) & 34.5 & 34.7 & 1.35 & 0.91 & -11.98 & 0.05 \\
\hline Läst temp OR (bladider) & 38 & 35.9 & 0.44 & 0.36 & -0.47 & 0.64 \\
\hline First tomp ICU (bladder) & 35.9 & 36.0 & 0.71 & 0.70 & -1.99 & 0.04 \\
\hline
\end{tabular}

The lowest temperalure in OR was $22.7^{\circ} \mathrm{C}$ for a patient in deep hypothermia in the standard group. Two patients had fever at the first measurement at the ICU, one patient in the standard group with $38.1^{\circ} \mathrm{C}$ and one patient in the test group with $38.8^{\circ}$ C. 33 patients $(18 \%)$ in the standard group and 24 patients $(12 \%)$ in the test group reached the value of the preoperative ward temperature at the end of the surgical procedure. 
The patients' body temperature $<36^{\circ} \mathrm{C}$ and $\leq 34.5^{\circ} \mathrm{C}$ as last temperature in $\mathrm{OR}$ and as the first temperature at the $I \mathrm{CU}$ is shown in table 6. A body core temperature $<36^{\circ} \mathrm{C}$ is defined as mild hypothermia. Thermoregulative vasoconstriction occurs at a body core temperature of $34.5^{\circ} \mathrm{C}$ (Kurz et al. 1995).

Table 6 Hypothemia in patients on standard and test table contiguration

\begin{tabular}{|c|c|c|c|c|c|c|}
\hline & \multicolumn{3}{|c|}{ Standaird group $n=183$} & \multicolumn{3}{|c|}{ Test group $n=207$} \\
\hline & $236^{\circ} \mathrm{C}$ & $\begin{array}{l}>34.5 \cdot \mathrm{C} \\
<36^{9} \mathrm{C}\end{array}$ & $534.5^{\circ} \mathrm{C}$ & & $\begin{array}{l}>34.5^{2} \mathrm{C} \\
<36^{2} \mathrm{C}\end{array}$ & $\$ 34.5^{\text {म }} \mathrm{C}$ \\
\hline Last temperature in $O A$ & $43 \%$ & $55 \%$ & $2 \%$ & $35 \%$ & $64 \%$ & 18 \\
\hline First temperature at ICU & $46 \%$ & $52 \%$ & $2 \%$ & $57 \%$ & $40 \%$ & $3 \%$ \\
\hline
\end{tabular}

\section{Discussion}

The overall pressure ulcer incidence in this study was $14.9 \%$. Patients positioned on a $4 \mathrm{~cm}$ thermoactive viscoelastic foam pad on an $O R$ table with a water filled warming mattress suffer slightly more pressure ulcers (17.4\%) than patients positioned on an OR table with the warming source but no pressure reducing device $(12 \%)$. The body core temperature courses during the operating procedure (lowest and last temperature in the operating room) and the first temperature at the intensive care unit for patients in the standard- and test table group are nearly equal. The $4 \mathrm{~cm}$ thermoactive viscoelastic foam pad between the patient and the heat source has no influence on the patients' body core temperature course.

132 patients $(34 \%)$ had a lowest temperature in the OR of $\leq 34.5^{\circ} \mathrm{C}$ which is stated as the temperature where thermoregulative vasoconstriction occurs (Kurz et al. 1995). Eleven patients had as first temperature at the ICU $\leq 34.5^{\circ} \mathrm{C}$. Following the last temperature measurement in OR the warming source stops, the OR clothes are removed, the patient is transported to the ICU - all these measures contain the possibility to loose warmth and reduce body temperature. An ongoing hypothermia $\left(<36^{\circ} \mathrm{C}\right)$ can result in postoperative shivering, a muscle shaking and increasing of muscle tonus as a reaction against the difference between the target temperature and the actual body core temperature. Shivering is a situation which the patients remember as very uncomfortable. The oxygen need increases (Bay et al. 1994), peripheral vasoconstriction and blood pressure increases (Frank et al. 1993, Frank et al. 1995) and peripheral oxygen saturation decreases (Jones \& McLarren 1965). Shivering can be seen as an adverse event. The $4 \mathrm{~cm}$ viscoelastic foam overlay is a barrier between the warming mattress and the patient. Therefor it could be assumed that the patients body 
temperature course in the re-warming phase of the cardiac surgery is different between the standard group where the patients were directly positioned on the warming mattress and the test group where the $4 \mathrm{~cm}$ viscoelastic foam overlay lays between the warming source and the patient. The results show no significant differences of the temperature means between the standard group and the test group. Only 31 Patients $(16 \%)$ in the standard group and 21 patients $(10 \%)$ in the test group finished the operation with equal or higher temperature as they had as last temperature on the ward. Over $80 \%$ of all patients had as first temperature at the ICU a lower temperature than as last one on the ward. Patients with temperature $<36^{\circ} \mathrm{C}$ at the first measurement at the ICU are routinely warmed with an air blanket. The effects of the additional warming devices for cardiac surgery patients in the OR are unclear. Some cardiac surgery units in Germany have rejected the warming device in the OR because the executives assume that rewarming of the patient through the cardiopulmonary bypass and through anaesthesiologic measures e.g., heated infusions, are sufficient.

Scott et al. (2001) report about the positive influence of intraoperative warming as additional measure to pressure ulcer prevention. In the logistic regression model temperature is no significant risk factor for pressure ulcer development in the here presented study. The overall pressure ulcer of $14.9 \%$ is comparable with findings from other studies in this population (Kemp et al. 1990, Papantonio et al. 1994, Jerusum et al. 1996, Lewicki et al. 1997, Stordeur et al. 1998, Pocorny 2003) which vary between $4.7 \%$ in the study of Lewicki et al. (1997) and $29.5 \%$ in the study of Stordeur et al. (1998). The patients on the test table suffered slightly more pressure ulcers than patients in the standard table group. The reasons for this phenomenon may be in the combination of the foam pad with a warming source and/or in the height of the overlay. The viscoelastic foam pad studied here is sensible to the body temperature of the patient. In combination with the body temperature the foam contours the body and reduces tissue interface pressure. The reaction of the viscoelastic foam pad in combination with an additional warming source is not described. This overlay is also used as a pressure reducing overlay in hospital beds. It is unclear how it works in situations were additionally warmth like fever occurs.

The $4 \mathrm{~cm}$ thermoactive viscoelastic foam overlay is not tested in a clinical trial. Hoshowsky \& Schramm (1994), Papantonio et al. (1994) and Nixon et al. (1998) tested a viscoelastic polymer pad which is a gel pad. Hawkins (1997) tested a foam pad and an air-filled pad against the standard operating table for patients who underwent cardiothoracic or major vascular surgery procedures. But she did not report about characteristics of the foam pad. 


\section{Conclusion}

Patients positioned on a $4 \mathrm{~cm}$ thermoactive viscoelastic foam pad on an OR table with a water filled warming mattress suffer slightly more pressure ulcers $(17.4 \%)$ than patients positioned on an OR table with the warming source but no pressure reducing device $(12 \%)$ in a cohort and an experimental study with 390 patients undergoing cardiac surgery procedures with ECC. The postoperative temperature course is not statistically different for patients lying directly on the warming source (water filled mattress) to patients lying on the $4 \mathrm{~cm}$ thermoactive viscoelastic polymer pad over the warming source.

A $4 \mathrm{~cm}$ thermoactive viscoelastic foam overlay on an OR table with a warming source is not effective to prevent patients to pressure ulcer and does not influence the patients temperature course. Recommended is a test with a seven or ten centimetre foam overlay for pressure ulcer prevention on the OR table (Krouskop et al. 1986) in combination with and without a warming source. Unclear is the reaction of the thermoactive foam with an additional warming source with a max. temperature of $36.5^{\circ} \mathrm{C}$. 


\section{References}

Aronovich SA, Wiber M, Slezak $S$, Martin T, Utter D (1999) A comparative study of an alkernating air mattress for the prevention of pressure ulcers in surgical patients. Ostomy/Wound Management $45,34-44$

Bay $J$, Nunn JF, Prys-Poberts $\mathrm{C}$ (1994) Factors influencing arterial $\mathrm{PO}_{2}$ during recovery from anaesthesia. British Journal of Anaesthesiology:40:398-407

Defloor T\& De Schujimer JDS (2000) Preventing pressure ulcers: an evaluation of four operatingtable mattresses. Applied Nursing Research 13(3), 134-41

EPUAP Europaan Pressure Ulcer Advisory Panel. Pressure Ulcer Treatment Guidelines. Avalable at: http//www. epuap orgl. Accessed February 04, 2005

Frank SM, Beattie C, Christopherson R, Norris EJ, Perler BA, Williarns GM, Gottlieb SO (1993) Unintentional hypothermia is associated with postoperative myocardial ischemia: The perioperative ischemia randomised anesthesia trial study group. Anesthesiology $78,468-76$

Frank SM, Higgins MS, Breslow MJ. Fleisher LA, Gorman AB, Silzmann $J V$, Raff H, Beattie C (1995) The catecholamine, cortisol and hemodynamic responses to mild perioperative hypothermia. A randomised clinical trial. Anesthesiology 82, 83-93

Hawkins JE (1997) The effectiveness of pressure-reducing table pads as an intervention to reduce risk of intraoperatively acquired pressure sores. Military Medicine 162(11), 759-61

Horn EP (2002) Perioperative Hypothermie: Pathophysiologie, Prophylaxe und Therapie. Anästhesie, Intensivmedizin, Notfalimedizin, Schmerztherapie 37(7), 409-28

Hoshowsky VM \& Schramm CA (1994) Intraoperative Pressure Sore Prevention: An Analysis of Bedding Materials. Research in Nursing Health 17, 333-39

Hoyman K, Gruber N (1992) A case study of interdepartmental cooperation: operating roomacquired pressure ulcers. Journal of Nursing Care Quality Suppl, 12-17

Jones HD, McLarren CAB (1965) Postoperative shivering and hypoxaemia after halothane, nitrous oxide and oxygen anaesthesia. British Journal of Anaesthesiology 37, 35-41

Jerusum J, Joseph K, Davis لJM \& Suki R (1996) Balloons, beds and breakdown. Criticall Care Nursing Clinics of North America $8,423-40$.

Kemp MG, Keithley JK, Smith DW, Morreale B (1990) Factors that contribute to pressure sores in surgical patients. Research in Nursing Health 13, $293-301$

Kosiak M (1959) Ethiology and pathology of ischemic ulcers. Archives of Physical Medicine \& Rehabilitation Feb, 62-69

Krouskop TA, Noble PS, Brown J \& Marburger R (1986) Factors affecting the pressure distributing properties of foam mattress overlays. Journal of Rehabilitation Research Development 23,33-39

Kurz A, Sessler DI, Birnbauer F, Illievich UM, Spiss CK (1995). Thermoregulatory vasoconstriction impairs active core cooling. Aneasthesiology 82, 870-876

Lewicki Lu, Mion L, Splane KG, Samstag D, Secic M (1997) Patient risk factors for pressure ulcer during cardiac surgery. AORN Journal $65(5), 933-42$

Nixon J, McElwenny, D, Mason S, Brown J \& Bond S (1998) A sequential randomised controlled trial comparing a dry visco-elastic polymer pad and standard operating table mattress in the prevention of post-operative pressure sores. International Journal of Nursing Studies $35,193-203$ 
Papantonio CT, Wallop KB \& Kolodner KB (1994) Sacral ullcers following cardiac surgery: incidence and risks. Advanced: Wound Care 7, 24-26

Pokorny ME, Koldjeski D, Swanson M. Skin Care Intervention For Patients Having CardiaC Surgery. Am J Crit Care 2003;12:535-544

Scott EM, Kelly PJ, Clark M, Leaper DJ (2001) Effects of warming therapy on pressure ulcers: a randomised trial. AORN Journal $73,921-938$

Scott EM (1999) Intra-operative warming for the prevention of post-operative complications. The Cochrane Library Issue 2

Stordeur S, Laurent S \& D Hoore W (1998) The importance of repeated risti assessment for pressure sores in cardiovascular surgery. Journal of Cardiovascular Surgery $39(3), 343-49$

Whittemore R (1998) Pressure-reduction support surfaces: a review of the literature. Journal of WOCN $25,6-25$ 


\section{CHAPTER 7}

General Discussion 
In this chapter, the results of the study projects, their relationships and special aspects are discussed. They are examined for their applicability to comparable settings and for their contribution to the "body of knowledge" in nursing.

\subsection{Main findings}

According to the literature study and the results of the studies in this dissertation, the following factors increase pressure ulcer risk in patients undergoing cardiac surgery: age $>60$ yrs. (Papantonio et al. 1994), the duration of the operation $\geq 375$ minutes (Papantonio et al. 1994) and situations that influence tissue tolerance for oxygen, such as antihypertensive and vasoactive drugs, hypotensive periods, preoperative hemoglobin level $(<12.7 \mathrm{~g} / \mathrm{dL})$, preoperative hematocrit level $(<38.7 \%)$ and additional diseases (diabetes mellitus, respiratory diseases, renal insufficiency, high APACHE score and comorbidities in general). This conclusion should be drawn with some reservations due to methodological differences in the observed variables, the skin assessment classification and observation points and the pressure ulcers included in the studies.

Use of the Failure Mode and Effects Analysis supports reduction of the pressure ulcer rate from $>30 \%$ in 2000 to $15 \%$ in 2004 . Improvement in the individual functions of ulcer prevention could be proven based on the risk potential number.

A standardised assessment of the individual risk in patients to develop pressure ulcers in the first five days after cardiac surgery by means of the Braden scale, the modified Norton scale and the 4-factor model did not show satisfactory results in differentiating between patients "at risk" and "not at risk" for pressure ulcer development.

In studies comparing the effect of a $4 \mathrm{~cm}$ viscoelastic foam mat on the operating table with the standard OR-table without foam mat, an RCT on 175 patients showed poorer results for the test configuration, with an ulcer rate of $17.6 \%$ vs. $11.1 \%$ for the standard configuration. In a convenience sample of 390 patients, an ulcer rate of $17.4 \%$ was found for the patients in the intervention group and $12 \%$ for the patients in the standard group. In the latter study, it was found that a $4 \mathrm{~cm}$ viscoelastic foam mat positioned between the patient and a heating pad had no significant influence on the course of the patient's body temperature.

\subsection{Risk factors and risk assessment}

Some of the special risk factors for pressure ulcer development in cardiac surgery patients found in the literature review also appear in the standardised risk assessment instruments. McGough (1999) identified the factor "age" in eleven risk assessment instruments, "major surgery/trauma" in six instruments, 
"nutrition/appetite" which can be related to the "albumin level" is part of 32 instruments and "additional diseases" in ten instruments. A "reduced hemoglobin" and "hematocrit level" and "blood pressure manipulation" can be related to "haemodynamic status" and to "tissue perfusion and oxygenation" which is part of two assessment scales. "Temperature" is a risk factor in three instruments while "temperature manipulation" does not take place in any of the evaluated instruments.

One risk assessment instrument which contains more risk factors is that by Salzberg et al. (1996). Published in 1996, this instrument, developed for spinal cord injury patients, includes the factors age, activity, mobility, continence (urine), tobacco use, albumin, haematocrit, diabetes, renal disease, pulmonary disease, cardiac disease, impaired cognitive function, nursing home, complete spinal cord injury and autonomic dysflexia or severe spasticity.

Risk factors affecting all cardiac surgery patients, regardless of the individual situation, are lying on the operating table for several hours, extracorporal circulation and body temperature manipulation. If assessment using an established instrument reveals a risk, this must be added to the basic risk, resulting in a total sum of the individual patient risk.

The results of the study project "Pressure ulcer risk assessment in the early postoperative ICU-period after cardiac surgery" show that risk assessment using the Braden scale rates more than $90 \%$ of patients at risk for pressure ulcer development in the first four postoperative days on the intensive care ward. If the basic risk from perioperative manipulations, which is not covered by this instrument, is added to this result, $100 \%$ of the patients are at risk for pressure ulcer development.

This study also reveals that the data for sensitivity, specificity, positive and negative predictive value were not suitable in any of the instruments applied to differentiate between patients at risk or not at risk for pressure ulcer development. The simple different frequency of patients identified as "at risk" by the three instruments is conspicuous.

Some methodological aspects in the development and use of risk assessment instruments should be discussed to clarify this result.

The standard for developing a risk assessment instrument is determination of the relevant concepts in pressure ulcer development, their ranking and weighting by statistical regression models. The number of patients included, the setting (longterm care, acute care, intensive care) and the special situation of compressive 
and shearing forces, tissue tolerance for pressure and tissue tolerance for oxygen form the basis for a model.

In the study by Halfens, van Achterberg: \& Bal (2000) on validity and reliability of the Braden scale in Dutch hospitals, it was found, that the factor "nutrition" which is a recognized risk factor in pressure ulcer development (Berlowitz \& Wilking 1989), was not seen as a relevant external criterion. The explanation was the definition of this criterion in the Braden scale as "intake of nutrition" and not as "nutritional condition". A patient with "sufficient intake of nutrition" can be in a "bad nutritional condition" and vice versa. Another example is the risk factor "moisture", which was not determined to be relevant for pressure ulcer development, although "incontinence"s and "sweating", offered as alternative situations were found to be significant factors. Even "mobility" and "activity", repeatedly described as risk factors in pressure ulcer development (Bergstrom et al. 1987, Defloor 1999, EPUAP 2005), were not found to be relevant. This example leads to the problem of nomenclature and operationalisation of the risk factors. The nomenclature of a risk factor guides the caregiver in making records. The description "the skin is wet" is interpreted differently than "the patient is incontinent".

The difference in concepts, their nomenclature, differentiation and ranking in the available risk assessment instruments reflects the play in the results of instrument development. In her evaluation of available risk assessment instruments, McGough (1999) demonstrates that the majority of more than 40 risk assessment instruments was developed on the basis of experts" knowledge, literature review and/or adaptation of one of seven original scales. The predictive power of an instrument is measured by sensitivity, specificity and the positive and negative predictive value. High sensitivity and specificity values show the capability of the instrument to differentiate between patients "at risk" and "not at risk". The positive and negative predictive values rate the predictive power of the instrument.

These measurements are basically influenced by the use of preventive measures in patients recognized by the caregiver's expertise as "at risk". This influence is not inconsiderable, since the preventive measures lead to falsification of the outcome variable "pressure ulcer yes/no" and thus to falsifications in the calculation.

The risk factors are found in various populations and varying circumstances. The residents of a nursing home, for example, are mostly limited in mobility and continence, while patients in a cardiosurgical intensive care unit are subjected to compression and shearing forces for a certain period of time and limited in food intake for a few days. The same assessment instrument is used for both patient 
groups. The differentiation and ranking of the individual risk factors leads to a total score which differentiates the patients as "at risk" and "not at risk" for pressure ulcer development. A regression analysis in each case would, with high probability, recognize for example immobility and incontinence in the nursing home and compression and shearing forces and nutrition in the cardiosurgical intensive care unit as significant for pressure ulcer development.

This can explain why, for example in the 4-factor model of Halfens et al. (2000) a basic risk factor like 'mobility' does not appear.

The methodological aspect of adjusting the cut-off point is already discussed in study three of this dissertation.

In their studies, Salvadena et al. (1992) and VandenBosch et al. (1996) demonstrate that sensitivity, specificity, positive and negative predictive value rated by the Braden scale are similar to results of clinical judgement of the caregivers. The use of standardised risk assessment instruments may be questioned on the basis of these results. The combination of education about risk factors in a particular population and screening by experienced caregivers may result in sufficient risk assessment. Risk assessment using standardised assessment instruments should be considered as a support for neophytes and caregivers with limited experience. It may be postulated that risk assessment by experienced caregivers makes the use of standardised risk assessment instruments unnecessary.

\subsection{Continuous quality improvement}

The reduction of the ulcer rate from $>30 \%$ in 2000 to $14.9 \%$ in 2004 can be attributed to quality improvement measures in the framework of the FMEA. The so-called "Hawthorne effect", "the effect on the dependent variable resulting from subjects " awareness that they are participants under study" (Polit \& Hungler 1999) must also be taken into consideration in this connection. According to colleague's statements, the fact that study nurses continuously came on ward, spoke with the patients in providing information on the topic of ulcers, that the results of the skin assessments of the patients and other data were recorded played an essential role for them. The factors attendant on the study were experienced as a constant reminder of ulcer prophylaxis and as a control. This "experience" and its effect on the individual colleague is an uncontrollable influence variable in the study.

Implementation of a controlling organ supports Management and colleagues in measuring the result of their organisational, personnel-political and nursing interventions, to compare them and use them for further decision. The importance 
of constant "monitoring" of quality indicators, such as ulcers in this case, draws the attention of the caregivers to the indicator. The art of supervision is to maintain the motivation and attention of the caregivers in the matter of ulcers at a constant level. Measures like continuous training, suitable standards, checking of processes (audits) and an events reporting system support this goal. Communication of the results via internal or external benchmarking strengthens the effect.

The methods in the quality management toolbox appear at first glance to be complicated and resource-intensive. In projects aimed at improving processes and reducing error frequency, these costs are amortized by gains in the value of the processes and a real reduction of errors and the costs they incur (Verstappen et al. 2004, Secretary of State for Health Learning from Bristol 2004). The costs to treat pressure ulcer are calculated in the literature at between $\$ 5000$ and $\$ 40.000$ (Allman 1986, Imman et al. 1993, Bours et al. 2002), depending on severityand excluding potential legal costs if the patient goes to court. A concrete cost-benefit calculation was not performed in the FMEA-project. Those responsible, however, assumed that the benefits for the patient are considerable. Moreover, the department can assume a favourable position in national benchmarking for the quality indicator "pressure ulcer" and its costs were reduced by the disappearance of severe pressure uicers, in the years 2003 and 2004 .

\subsection{Pressure reducing device on the OR-table}

The use of pressure-reducing devices results from the assumption that these systems delay or prevent occlusion of capillary vessels. The objective is to maintain capillary flow in situations in which external pressure is exerted on the tissue and/or internal factors negatively influence the autoregulation mechanism for adaptation of intravasal pressure (Klinke \& Silbernagl 2001).

The $4 \mathrm{~cm}$ thermoactive viscoelastic foam overlay is not useable in conjunction with a direct-applicable heat source for pressure ulcer prevention on the operating table. The results of pressure ulcer incidence in the study performed are slightly higher for patients on the test table with the $4 \mathrm{~cm}$ foam overlay than on the standard table without overlay. The use of effective pressure-relieving devices on the operating table still appears to be a challenge for nursing scientists and caregivers. According to Defloor's study, in which five operating table overlays were tested for reduction of interface pressure, none of the overlays reduces pressure sufficiently to prevent occlusion of the capillary vessels due to pressure. The manufacturers of pressure-reducing foam overlays are urged to continue 
development, particularly toward thermo-inactive viscoelastic foams. At the moment, only one company in Europe offers foam in thicknesses of $5 \mathrm{~cm}$ or more (Reha Med Technology 2005).

With respect to temperature regulation of patients undergoing cardiosurgical procedures ${ }_{n}$ systems on which the patient can be placed are recommended for use whenever possible. Other possibilities must be found for patients with two operating fields, e.g. thorax and legs for vene harvesting.

Scott recommends air systems that enable both pressure reduction and warming as operating table overlays. No data are available for patients undergoing cardiosurgical procedures. The results of a test in the Department of Cardiovascular Surgery were unsatisfactory with respect to practical use of the systems.

While results are available for viscoelastic polymer devices on operating room tables (Papantonio et al. 1994, Hoshowsky \& Schramm 1994, Nixon et al. 1998), no studies have been performed on thermoactive viscoelastic foams. 


\section{References}

Allman RM el al. Pressure sores among hospitalised patients. Ann Internal Med. 1986;105:337342

Bergstrom N, Braden Bd, Laguza A, Holman W. The Braden scale for predicting pressure sore risk. Nurs Res: 1987,36:205-210

Beriowitz DR, Wifking SV. Fisk factors for pressure sores: A comparison of cross-sectional and cohort-derived data. I Am Ger Soc. 1989,37:1043-1050

Bours GJJW, Halfens RJG, Huijer Abu-Saad H, Grol RTPM. Prevalence prevention and treatment of pressure ulcers: Descriptive study in 89 Institutions in the Netherlands. Res Nurs Health. 2002;25(2);99-110

Defloor T. The risk of pressure sores: a conceptual scheme. J Clin Nurs. 1999:8:206-16

European Pressure Ulcer Advisory Panel. Pressure Ulcer Prevention Guidelines. hitp:/66,70.207.8/alprevention.htm! Accessed February 12,2005

Halfens $R J G$, van Achterberg T, Bal RM. Validity and reliability of the Braden and the influence of other risk factors: a multi-centre prospective study. Int J Nurs Stud. 2000;37:313-319

Hoshowsky VM, Schramm CA. Intraoperative pressure sore prevention: an analysis of bedding materials. Res Nurs and Health. 1994;17:333-339

Imman KJ, Sibbald WJ, Rutledges FS, Clark BJ. Clinical utility and cost effectiveness of an air suspension bed in the prevention of pressure ulcars. JAMA. 1993:269:1139-1143

Klinke R, Silbernagl S. Lehrbuch der Physiologie. 3d ed, Stuttgart: Thieme Verlag; 2001

McGough A. A systematic review of the effectiveness of risk assessment scales used in the prevention and management of pressure sores. MSc. Thesis, University of York; 1999

Nixon J, McElvenny D, Mason S, Brown لl, Bond S. A swquential randomised controlled trial comparing a dry visco-elastic polymer pad and standard operating table mattress in the prevention of post-operative pressure sores. Int J Nurs Stud. 1998;35:193-203

Papantonio CT, Wallop KB, Kolodner KB. Sacral ulcers following cardiac surgery: Incidence and risks. Adv Wound Care 1994;7:24-26

Polit D.F., Hungler B.P.: Nursing research: principles and methods. Philadelphia: Lippincott Williams \& Wilkins, $1999,6^{\text {th }}$ ed., 703

Ficha Med Technology. http://www rmt-rehamed.de. Accessed December 15, 2004

Salvadena $\mathrm{G}$, Snyder $\mathrm{ML}_{4}$ Brogdon KE. Clinical trial of the Braden scale on acute care medical unit. Journal of Enterostomal Therapy. 1992;19:160-65

Salzberg CA, Byrne DW, Cayten CG, van Niewerburgh P, Murphy JG, Viehbeck M. A new pressure ulcer risk assessment scale for individuals with spinal cord injury. American Journal of Physical Medicine and Rehabilitation. 1996;75(2):96-104

Secretary of State for Health Learning from Bristol. Report of the public inquiry into children's heart surgery at the Bristol Royal Infirmerary 1984-1995, presented to Parliament by the Secretary of State for Heath by Command of Her Majesty July 2001. http://www bristolinquiry.org.uk. Accessed December 12, 2004 
VandenBosch T. Montonye $C$. Satwicz M, Durkee-Leonard K, Boyland Lewis B. Predictive validity of the Braden scale and nurse perception in identifying pressure ulcer risk. Applied Nursing Research. 1996;9(2):80-86

Verstappen W, van Merode F, Grimshaw W, Dubois $W_{i}$ Grol $R_{1}$ van Der Weijden T. Comparing cost effects of two quality strategies to improve test ordering in primary care: a randomised trial. Int I Qual Health Care. 2004;16:391-398 


\section{CHAPTER 8}

Recommendations 


\subsection{Recommendations for practice}

Patients who must undergo cardiac surgery have a basic risk for the development of ulcers due to the perioperative manipulations.

Prevention measures should be aimed at supporting tissue tolerance for pressure and tissue tolerance for oxygen, since these are the significant risk indicators in this population.

The preoperative albumin level, haemoglobin level and haematocrit level should be normalized. The older the patient, the more diseases present and the longer the surgical procedure, the greater the risk of pressure ulcer development. A sufficient pressure reduction on the OR-table is recommended. Intraoperative, a normothermic ECC and sensitive blood pressure management with a minimum of hypotensive periods should be realized whenever possible. Effective postoperative pressure ulcer prevention with pressure relieving in bed, continuous patient turnings and early mobilisation are standard measures in this population. Where these preventive measures in the intermediate postoperative period in the intensive care unit are standardised, a static risk assessment by the Braden scale, the modified Norton scale and the 4-factor model does not lead to more effective pressure ulcer prevention. With this background, it can be recommended that an individual risk assessment be dispensed with during intensive care in the first five postoperative days following cardiosurgical procedures.

It must be recommended to the nursing staff that $4 \mathrm{~cm}$ thermoactive viscoelastic foam overlays should not be used in conjunction with a direct-application heat source for pressure ulcer prevention on the operating table. The results of pressure ulcer incidence in the study performed are slightly higher for patients on the test table with the $4 \mathrm{~cm}$ foam overlay than on the standard table without overlay. The use of effective pressure-relieving devices on the operating table still appears to be a challenge for nursing scientists and caregivers.

In principle, the use of quality management instruments can be recommended to those responsible for health-care facilities and nursing staff with respect to improvement in the pressure ulcer prevention process. The results of the study project "The Effect of the Failure Mode and Effects Analysis Model on Pressure Ulcer Incidence in Cardiac Surgery" show that improvement of the pressure ulcer incidence could be achieved. In projects aimed at improving processes and reducing error frequency, these costs are amortized by gains in the value of the processes and a real reduction of errors and the costs they incur (Verstappen et al. 2004, Secretary of State for Health Learning of Bristol, 2005). 
With respect to temperature regulation of patients undergoing cardiosurgical procedures, heating systems which can be placed on the patient are recommended for use whenever possible. Other possibilities must be found for patients with two operating fields, e.g. thorax and legs for vene harvesting.

\subsection{Recommendations for further research}

According to the results of the literature review on risk factors in cardiac surgery, further research is necessary to support the findings in the population studied. For example, time on the OR table in combination with pressure-relieving devices, differences in temperature and blood pressure management and differences in mobility activities after surgery should be examined scientifically in connection with pressure ulcer occurrence.

One recommendation for further research projects on risk factors in cardiosurgical patients is development of a common research model. The following points must be taken into account as the minimum requirements for comparability and generalization of the data:

1. Definition of the minimum data set:

Compressive and shearing forces

Body mass index

OR time

Preventive measures peril- and postoperative

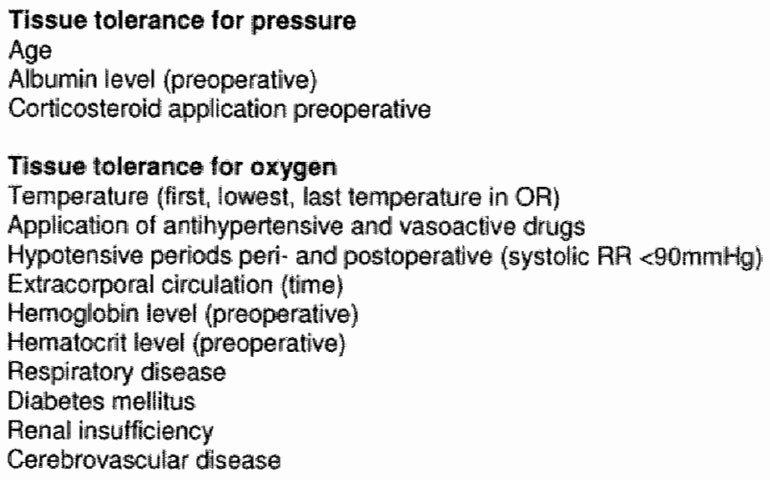

2. Use of the pressure ulcer classification system of the North America Pressure Ullcer Advisory Panels or the European Pressure Ullcer Advisory Panel;

3. Performance of skin assessments immediately preoperative, immediately postoperative (time up to max. 1 hour after transfer of the patient from the operating table to the bed), further at least on the first postoperative day and then every second day, but at least up to the fifth postoperative day; 
4. Inclusion in the incidence figures of any pressure ulcer diagnosed as grade 1 , independent of its time of healing;

5. Inclusion of all pressure ulcer grades;

6. Assessment of the data by regression models.

With respect to pressure ulcer risk assessment in intensive care patients, studies are needed to verify the results of the project "Pressure uicer risk assessment in the early postoperative ICU-period after cardiac surgery". The problem remains that the prevention measures undertaken alter the pressure ulcer incidence and thus falsify the assessment of the risk assessment instruments. This vicious circle cannot presently be broken. Several authors recommend to include the preventive measures in the calculation of an instrument's capability to differentiate between patients at risk and not at risk. Using cardiosurgical intensive-care patients as an example, all patients must be considered "at risk" during the first postoperative days, in the judgement of experienced nurses. All patients receive standardised pressure ulcer prevention measures (pressure ulcer prevention mattress, regular shift in position, early mobilisation). True negative results can thus not be distinguished from true positive results by an instrument. Sensitivity, specificity, positive and negative predictive value can no longer be calculated. Despite this fact, risk assessment instruments are helpful in screening for risk factors, for which targeted preventive measures may be initiated.

One important resarch field lies in pressure ulcer prevention on the operating table. Which operating tables and overlay systems are sufficient to reduce interface pressure and lead to reduction of the pressure ulcer incidence should be examined in further studies. Thus far, results are available on viscoelastic polymer devices on operating tables from Hoshowski \& Schramm (1994), Nixon et al. (1998) and Papantonio et al. (1994). No studies have been published on thermoactive viscoelastic foams. The surgical intervention on the operating table usually makes repositioning of the patient impossible. Since the standard operating table is covered with a polyurethane overlay, which can be rated "hard", the formula "pressure $x$ time" takes full effect as the factor mainly responsible for capillary occlusion (Kosiak 1959). In addition, the tissue tolerance for oxygen is detrimentally influenced in patients undergoing cardiosurgical procedures by the interventions in circulation and temperature. Another challenge is to differentiate between the various foams available on the market. For those responsible in the 
facility and for caregivers, it is practically impossible to distinguish between the pressure-reducing properties of polyurethane foam, polyether foam, viscoelastic foam and other kinds of foams. A presentation from the nursing science perspective would be helpful. 


\section{References}

Hoshowsky VM, Schramm CA. Intraoperative pressure sore prevention: an analysis of bedding malerials. Res Nurs and Health. 1994:17:333-339

Kosiak M. Etiology and Pathology of Ischemic Ulcers. Arch Phys Med Rehab. 1959; February:6269

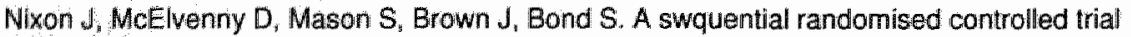
comparing a dry visco-elastic polymer pad and standard operating table mattress in the prevention of post-operative pressure sores. Int II Nurs Stud. 1998;35:193-203

Papantonio CT, Wallop KB, Kolodner KB. Sacral ulcers following cardiac surgery: Incidence and risks. Adv Wound Care 1994;7:24-26

Secretary of State for Health Learning from Bristol. Report of the public inquiry into children"s heart surgery at the Bristol Royal Infirmerary 1984-1995, presented to Parliament by the Secretary of State for Health by Command of Her Majesty Jully 2001, http//www bristolinquiry.org.uk. Accessed December 12,2004

Verstappen W, wan Merode F, Grimshaw W, Dubois W, Grol R, van Der Weijden T. Comparing cost effects of two quality strategies to improve test ordering in primary care: a randomised trial. Int $J$ Qual Health Care. 2004;16: 391-398 
Summary 
Chapter 1 , the Introduction, presents the practice problem underlying this dissertation. The rate of pressure ulcer among cardiac surgery patients has been described in the literature as between $4.7 \%$ and $29.5 \%$. In light of a pressure uicer rate of $>30 \%$ and the development of serious decubitus in the Department for Cardiovascular Surgery at the University Hospital Freiburg in the years $1999 / 2000$, research projects were initiated to improve the situation. Also in the Introduction, the risk factors involved in the occurrence of pressure ulcers are discussed on the basis of Defloor's "conceptual scheme depicting factors in the etiology of pressure sores" Knowledge with regard to the development of pressure ulcers is discussed. The current state of scientific discussions of risk assessment instruments and requirements for prevention are presented, as is the spezial situation of cardiosurgical patients in connection with the development of a pressure ulcer. The Introduction closes with a presentation of the study projects.

Chapter 2 describes the literature study entitled: "Pressure ulcer risk factors in cardiac surgery: A review of the research literature". This study addressed the question of special risk factors. It was found that, despite methodological differences, the patient $>60$ years, undergoing surgery lasting $\geq 375$ minutes with additional situations and diseases affecting the tissue tolerance for oxygen, e.g. low hemoglobin, low haematocrit, low albumin, hypothermic extracorporeal circulation, hypotonic phases, diabetes, renal insufficiency, pulmonary disease and comorbidities in general, is at risk for pressure ulcer development during and following cardiosurgical procedures.

Chapter 3 illustrates the project "The Effect of the Failure Made and Effects Analysis Model on Pressure Ulcer Incidence in Cardiac Surgery" focused on recording error possibilities, their assessment and possible influence in the process of pressure ulcer prevention. It could be demonstrated that this quality management method contributed to the reduction of pressure ulcer incidence from $31 \%$ in January 2001 to $15 \%$ in December 2003 by avoiding possible errors in pressure ulcer prevention elements.

Chapter 4 presents the study project "Pressure ulcer risk assessment in the early postoperative ICU-period after cardiac surgery". In this study the Braden scale, the modified Norton scale and the 4-factor model were used to assess the patient's risk for pressure ulcer development during a maximum of five days in the intensive care unit. It revealed that individual risk assessment using the Braden scale rates more than $90 \%$ of the patients in the first four postoperative 
days and more than $80 \%$ on the fifth postoperative day as at risk of pressure ulcer. The association parameters were not satisfactory.

Chapter 5 reports on the study project "The effect of a $4 \mathrm{~cm}$ thermoactive viscoelastic foam pad on the operating table on pressure ulcer incidence during cardiac surgery". In a randomised controlled trial with 175 patients, a test $O R$ table configuration with a $4 \mathrm{~cm}$ thermoactive viscoelastic foam overlay and a heating pad was compared to the standard OR-table configuration with heating pad but without foam overlay. $17.6 \%$ of the patients on the test OR-table with the $4 \mathrm{~cm}$ viscoelastic foam overlay and $11.1 \%$ patients on the standard table showed a pressure ulcer postoperatively.

Chapter 6 describes a quasi-experimental study with a convenience sample of 390 patients to test the effect of a $4 \mathrm{~cm}$ viscoelastic foam overlay on the OR-table on the patient's body temperature course and the postoperative pressure ulcer incidence. It was hypothesized that the patients on the test operating table configuration with a heating source and the foam overlay would have a different body temperature course than patients on the standard table configuration because the overlay was placed between the heating source and the patient. In this study, $17.4 \%$ patients on the operating room table with the $4 \mathrm{~cm}$ viscoelastic foam overlay and $12 \%$ patients on the OR-table without the foam overlay suffered pressure ulcer. The patients" body temperature courses were not significantly different between the two groups.

Chapter 7 presents a summary of the main findings and some theoretical reflections on study results. Methodological aspects of interest include risk assessment, continuous improvement measures and the knowledge of pressure reducing devices on the operating room table.

Chapter 8 describes recommendations for practice and further research. For practice, the integration of the presented study results in pressure ulcer prevention management for cardiac surgery patients is recommended. Further research should focus on a common research model and on investigations of pressure ulcer prevention on the operating room table. 
Samenvatting 
Hoofdstuk 1, de introductie "beschrijft het probleem vanuit de praktijk en vormt de basis van dit proefschrift. Het aantal hartchirurgiepatiënten dat decubitus heeft bedraagt volgens de literatuur tussen de 4.7 en $29.5 \%$. Uitgaande van een percentage van meer dan dertig en het aanwezig zijn van decubitus op de afdeling voor cardiovasculaire chirurgie in het academisch ziekenhuis in Freiburg in de jaren 1999/2000, werden onderzoeksprojecten gestart om de situatie te verbeteren.

Verder worden in de introductie de risicofactoren die een rol spelen bij het voorkómen van decubitus op basis van Defloors "conceptual scheme depicting factors in the etiology of pressure sores" besproken.

Er wordt ingegaan op de kennis over het ontstaan van decubitus. Aan de orde komen de huidige stand van kennis over de instrumenten die het risico op het ontstaan van decubitus aangeven, de voorwaarden voor preventie, en ook de bijzondere situatie van patiënten op de hartchirurgie in relatie tot het ontstaan van decubitus. Hoofdstuk 1 sluit af met een overzicht van alle onderzoeksprojecten uit ditt proefschrift.

Hoofdstuk 2 is het verslag van de literatuurstudie met de titel: "Risicofactoren voor het ontstaan van decubitus op de cardiochirurgie: een overzicht van onderzoeksrapporten". Het gaat hier om de vraag naar speciale risicofactoren. Ondanks methodologische verschillen werden de volgende resultaten gevonden. Patiënten ouder dan 60 jaar, welke een cardiologische operatie ondergaan die langer dan 375 minuten duurt en bijkomende complicaties en ziektes hebben die de weefseltolerantie voor zuurstof beïnvloeden, lopen het risico om tijdens en na cardiochururgische ingrepen decubitus te krijgen. Hierbij gaat het om de volgende ziektes en complicaties: een laag hemoglobinegehalte, lage hematocrietwaarden, een laag albuminegehalte, een hypothermische extracorporale circulatie, hypotone fases, diabetes, renale insufficiëntie, pulmonale ziektes en andere begeleidende ziektetoestanden in het algemeen.

Hoofdstuk 3 beschrijt het project "The effect of the Failure Mode and Effects Analysis Model on Pressure Ulcer Incidence in Cardiac Surgery" " dat gericht is op het registreren van mogelijke fouten, hun beoordeling en hun mogelijke invloed op het proces van de preventie van decubitus. Er kon vastgesteld worden dat door het voorkomen van mogelijke fouten in de decubituspreventie er een reductie van het vóórkomen van decubitus optrad van 31\% in januari 2001 tot $15 \%$ in december 2003. 
Hoofdstuk 4 bespreekt het onderzoeksproject "Pressure ulcer risk assessment in the early postoperative ICU-period after cardiac surgery. Hierbij wordt de Bradenschaal, de aangepaste Nortonschaal en het 4-factoren model gebruikt, om gedurende maximaal 5 dagen het risico woor de ontwikkeling van decubitus bij patiënten op de intensive care te bepalen. Er werd aangetoond dat de individuele risicobeoordeling bij het gebruik van de Bradenschaal tijdens de eerste vier postoperatieve dagen meer dan $90 \%$ en op de vijfde postoperatieve dag meer dan $80 \%$ van de patiënten als risicopatiënt voor de ontwikkeling van decubitus aanwees. De parameters welke daarmee in verband gebracht werden, voldeden niet.

Hoofdstuk 5 behandelt het project "The effect of a $4 \mathrm{~cm}$ thermoactive viscoelastic foam pad on the operating table on pressure ulcer incidence during cardiac surgery". In een gerandomiseerd vergelijkend onderzoek met 175 patiënten werd een testopstelling met een operatietafel met een $4 \mathrm{~cm}$ dikke viscoelastische schuimmatras met verwarmingskussen vergeleken met een standaard operatietafel met verwarmingskussen, maar zonder schuimmatras. $17.6 \%$ van de patiënten op de testtafel met de $4 \mathrm{~cm}$ dikke viscoelastische schuimmatras en $11.1 \%$ van de patiënten op de standaard tafel hadden postoperatief decubitus.

Hoofdstuk 6 beschrijt een quasi-experimenteel anderzoek met een steekproef van 390 patiënten om het effect van een $4 \mathrm{~cm}$ dikke viscoelastische schuimmatras op de operatietafel op het verloop van de lichaamstemperatuur van de patiënt en het voorkómen van postoperatieve decubitus te testen. Er werd verondersteld, dat de patiënten op de testopstelling met het verwarmingselement en schuimmatras een andere lichaamstemperatuurcurve hebben dan patiënten op een standaard operatietafel, omdat de matras tussen het verwarmingselement en de patiënt geplaatst werd. In dit onderzoek had $17.4 \%$ van de patiënten op de operatietafel met de $4 \mathrm{~cm}$ dikke schuimmatras en $12 \%$ van de patiënten op de operatietafel zonder schuimmatras, decubitus. Tussen de beide groepen waren de lichaamstemperatuurcurven niet significant verschillend.

Hoofdstuk 7 bevat de samenvatting van de voornaamste resultaten en enkele theoretische overwegingen over de onderzoeksresultaten. Methodologisch interessante aspecten zoals risicobeoordeling, voortdurende verbeteringsmaatregelen en de kennis van drukreducerende middelen op de operatietafel worden thier nogmaals besproken. 
Hoofdstuk 8 geeft aanbevelingen voor de praktijk en voor verder onderzoek. Voor de praktijk wordt de integratie van de beschreven onderzoeksresultaten in de preventie van decubitus bij patienten op de cardiochirurgische afdeling aanbevolen. Verder onderzoek zou de nadruk moeten leggen op een gemeenschappelijk onderzoeksmodel en op onderzoek naar preventie van decubitus. 
Zusammenfassung 
Kapitel 1, die Einführung, beschreibt die Praxisprobleme wellcher dieser Dissertation zugrundeliegen. Die Dekubitusrate bei kardiochirurgischen Patienten ist in der Literatur mit $4.7 \%$ bis $29.5 \%$ beschrieben. Auf dem Hintergrund einer Dekubitusrate von $>30 \%$ und der Entwicklung von schwergradigen Dekubitus in der Abteilung für Herz- und GefăBchirurgie am Universitätsklinikum Freiburg in den Jahren 1999/2000, wurden Forschungsprojekte zur Verbesserung dieser Situation initiiert. Des Weiteren werden in der Einführung die Risikofaktoren für eine Dekubitusentstehung auf dem Hintergrund von Defloor's "konzeptuellen Schema zur Erfassung von Faktoren in der Ätiologie von Dekubitus" diskutiert. Der aktuelle Stand der wissenschaftlichen Diskussion zu Risikoeinschätzungsinstrumenten und den Erfordernissen in der Prävention in der speziellen Situation des kardiochirurgischen Patienten, im Zusammenhang mit der Entwicklung von Dekubitus, wird ebenfalls vorgestellt. Die Einführung schließt mit der Darstellung der Studienprojekte.

Kapitel 2 beschreibt die Literaturstudie mit dem Titel "Dekubitusrisikofaktoren in der Herzchirurgie: Eine Review der Forschungsliteratur". Diese Studie addressiert die Frage nach den speziellen Dekubitusrisikofaktoren bei kardiochirurgischen Patienten. Das Ergebnis zeigt, dass Patienten $>60$ Jahre mit kardiochirurgischen Eingriffen $>375$ Minuten und zusätzlichen Situationen und Faktoren die die Gewebetoleranz für Sauerstoff beeinflussen, z.B. niedriges Hämoglobin, niedriger Hämatokrit, niedriges Albumin, hypothermische extrakorporale Zirkulation, hypotone Phasen, Diabetes mellitus, Niereninsuffizienz, Lungenerkrankungen und generelle Multimorbidität, einem Risiko für die Entwicklung eines Dekubitus während oder nach dem kardiochirurgischen Eingriff ausgesetzt sind.

Kapitel 3 stellt das Projekt "Der Effekt der Fehlermöglichkeits- und Einflussanalyse auf die Dekubitusinzidenz in der Herzchirurgie" dar, in welchem Fehlermöglichkeiten sowie deren Erfassung und Einfluss im Prozess der Dekubitusprävention aufgezeigt werden. Es konnte demonstriert werden, dass diese Qualitätsmanagementmethode zur Reduktion der Dekubitusinzidenz von $31 \%$ im Januar 2001 auf 15\% im Dezember 2003 durch die Vermeidung von möglichen Fehlern im Prozess der Dekubitusprävention beigetragen hat. 
Kapitel 4 präsentiert das Studienprojekt "Dekubitusrisikofaktoren nach kardiochirurgischen Eingriffen in der frühen postoperativen Intensivpflegephase". In dieser Studie werden die Bradenskala, die modifizierte Nortonskala und das 4Faktoren Modell eingesetzt um das postoperative Dekubitusrisiko der Patienten bis zu einer Liegedauer von maximal fünf Tagen auf der Intensivstation zu erfassen. Es zeigte sich, dass bei einem Risikoassessment mit der Bradenskala in den ersten vier Tagen mehr als $90 \%$ der Patienten und am fünften postoperativen Tag mehr als $80 \%$ als Risikopatienten zur Dekubitusentstehung bewertet wurden. Die ermittelten Assoziationsmaße waren nicht zufriedenstellend.

Kapitel 5 berichtet vom Studienprojekt "Der Effekt einer $4 \mathrm{~cm}$ thermoaktiven viscoelastischen Schaumauflage auf dem Operationstisch auf die Dekubitusinzidenz bei kardiochirurgischen Patienten". In einer randomisierten kontrollierten Studie mit 175 Patienten wurde eine TestOperationstischkonfiguration mit einer $4 \mathrm{~cm}$ thermoaktiven viscoelastischen Schaumauflage und einer Wärmematte mit der StandlardOperationstischkonfiguration mit Wärmematte aber ohne Schaumauflage verglichen. Bei $17.6 \%$ der Patienten auf dem Test-Operationstisch mit der $4 \mathrm{~cm}$ thermoaktiven viscoelastischen Schaumauflage und $11.1 \%$ der Patienten auf dem Standard-Operationstisch wurde postoperativ ein Dekubitus festgestellt.

Kapitel 6 beschreibt eine quasi-experimentelle Studie mit einer Gelegenheitsstichprobe von 390 Patienten. In dieser Studie wurde der Effekt einer $4 \mathrm{~cm}$ thermoaktiven viscoelastischen Schaumauflage auf dem Operationstisch auf den Verlauf der Körpertemperatur des Patienten und auf die postoperative Dekubitusinzidenz untersucht. Es wurde angenommen, dass die Patienten auf dem Test-Operationstisch mit einer Wärmematte und der Schaumauflage einen anderen Körpertemperaturverlauf haben als die Patienten auf dem Standard-Operationstisch, da die Schaumauflage zwischen der Wärmematte und dem Patienten plaziert wurde. In dieser Studie wurde postoperativ bei $17.4 \%$ der Patienten auf dem Test-Operationstisch und beil $12 \%$ der Patienten auf dem Standard-Operationstisch ein Dekubitus festgestellt. Die Verläufe der Körpertemperaturen der Patienten in den beiden Gruppen war nicht signifikant unterschiedlich. 
Kapitel 7 präsentiert eine Zusammenfassung der Hauptergebnisse und eine Reflexion der Studienergebnisse. Diskutiert werden methodologische Aspekte zu Risikbeinschätzungsinstrumenten, zum kontinuierlichen Verbesserungsprozess und zum Wissen zu druckreduzierenden Auflagen auf dem Operationstisch.

Kapitel 8 beschreibt Empfehlungen für die Praxis und für weiterführende Forschungsvorhaben. Für die Praxis wird die Integration der vorhandenen Studienresultate zur Dekubitusprävention bei kardiochirurgischen Patienten empfohlen. In weiteren Forschungsvorhaben sollten die Entwicklung eines gemeinsamen Forschungsmodells und Untersuchungen zu einer suffizienten Dekubitusprävention auf dem Operationstisch im Mittelpunkt stehen. 


\section{Acknowledgements}

I wish to express my thanks to my supervisors, Rob de Bie, Theo Dassen and Ruud Halfens for their ideas, suggestions for improvements and for their patience. I could always rely on their invaluable support, for which I am very grateful.

Furthermore I thank Mrs. Buchstor (Director of Nursing Care), Prof. Dr. Beyersdorf (Head of the Department of Cardiovascular Surgery), Prof. Dr. Schulte-Mönting (Institute of Medical Biometry and Medical Informatics), Dr. Zahhringer (Centre for Clinical Studies) for their continuous support over the years, and all colleagues and nurses at the University Hospital who participated in the studies for their engagement.

I also thank Doris and Barbara, my paranymfes, who often helped me to find new directions, and Linda for the Dutch segments in this thesis.

My thanks also go to my family who motivated me to keep going. Finally I am greatly indebted to my friend Maria for her encouragement and support during all stages of this endeavour. This thesis would never have been completed without her. 


\section{Curriculum vitae}

Johanna Feuchtinger was born in Haselbach/Bavaria, Germany, on July $31^{\text {st }}$, 1959. In 1979 she finished her Professional Training for Nursing Care at the "State Accredited School of Nursing - of the Barmherzigen Schwestern von Vinzenz von Paul" in München, Germany. In the following years she worked as nurse in different units at the University Hospital Steglitz in Berlin and at the University Hospital Freiburg, Germany. In 1987 she began a two-year postgraduate program to obtain a license as "Teacher and Manager for Schools of Nursing" at the Catholic Institute for Further Education in Nursing Freiburg. After that she worked for five years as Nursing Director at the Clinic for Internal Medicine and seven years at the Clinics for Neurology and Neurosurgery at the University Hospital Freiburg, Germany.

From 1996 to 1999 she studied Nursing Science at the Universiteit Maastricht, The Netherlands, and the University of Applied Sciences in Aarau, Switzerland, obtaining a Masters in Nursing Science.

Since 2002 she has been working as an Assistant of the Head of Nursing, responsible for Quality and Development in Nursing Care at the University Hospital Freiburg. She is a member of the Quality Counsel at the University Hospital and a member of the Ethics Committee of the University Freiburg.

She started the studies described in this thesis in March 2001. 